\title{
New observations on the role of VEGF/VPF and nitric oxide in the vessel wall
}

Citation for published version (APA):

van der Zee, M. C. (1997). New observations on the role of VEGF/VPF and nitric oxide in the vessel wall. [Doctoral Thesis, Maastricht University]. Universiteit Maastricht. https://doi.org/10.26481/dis.19971219mvz

Document status and date:

Published: 01/01/1997

DOI:

10.26481/dis. $19971219 \mathrm{mvz}$

Document Version:

Publisher's PDF, also known as Version of record

\section{Please check the document version of this publication:}

- A submitted manuscript is the version of the article upon submission and before peer-review. There can be important differences between the submitted version and the official published version of record.

People interested in the research are advised to contact the author for the final version of the publication, or visit the DOI to the publisher's website.

- The final author version and the galley proof are versions of the publication after peer review.

- The final published version features the final layout of the paper including the volume, issue and page numbers.

Link to publication

\footnotetext{
General rights rights.

- You may freely distribute the URL identifying the publication in the public portal. please follow below link for the End User Agreement:

www.umlib.nl/taverne-license

Take down policy

If you believe that this document breaches copyright please contact us at:

repository@maastrichtuniversity.nl

providing details and we will investigate your claim.
}

Copyright and moral rights for the publications made accessible in the public portal are retained by the authors and/or other copyright owners and it is a condition of accessing publications that users recognise and abide by the legal requirements associated with these

- Users may download and print one copy of any publication from the public portal for the purpose of private study or research.

- You may not further distribute the material or use it for any profit-making activity or commercial gain

If the publication is distributed under the terms of Article $25 \mathrm{fa}$ of the Dutch Copyright Act, indicated by the "Taverne" license above, 


\title{
New observations on the role of VEGF/VPF and nitric oxide in the vessel wall
}

\author{
PROEFSCHRIFT \\ ter verkrijging van de graad van doctor \\ aan de Universiteit Maastricht, \\ op gezag van de Rector Magnificus, Prof. mr. M.J. Cohen, \\ volgens het besluit van het College van Decanen, \\ in het openbaar te verdedigen \\ op vrijdag 19 december 1997 om 10.00 uur \\ door
}

Marinus Cornelis van der Zee

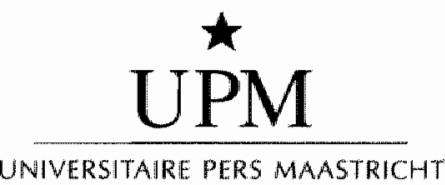




\section{Promotores:}

Prof. dr. H.J.J. Wellens

Prof dr. M.J.A.P. Daemen

Beoordelingscommissie:

Prof. dr. R. Reneman (voorzitter)

Prof. dr. C. Borst, Universiteit Utrecht

Prof. dr. T.W.A. de Bruin

Prof. dr. ir. Havekes, TNO Preventie en Gezondheid, Leiden

Prof. dr. J. De Mey

Financial support by the Foundation "Hartsurienden RESCAR" and the Durch Heart Foundacion for publication of this thesis is gratefully acknowledged.

Additional financial support of the following companies has been appreciated:

Bayer bv, Byk Nederland bv, Knoll bv, Leo Pharmaceutical Products bv, Lorex Synthélabo bv, Menarini Farma NL. MSD. Parke Davis bv, Pfizer bv, Roche Pharmaceuticals, Sanofi Winthrop, Servier Nederland bv, Tramedico bw. 


\section{Contents}

Abbreviations 6

Chapter 1

Introduction 9

\section{Chapter 2}

Vascular endothelial growth factor/vascular permeability factor augments nitric oxide release from quiescent rabbit and human vascular endothelium. $\quad 29$

\section{Chapter 3}

The human internal mammary artery releases more nitric oxide in response to vascular endothelial growth factor/vascular permeability factor than the human saphenous wein. Evidence for VEGF/VPFreceptors in quiescent human endothelium. 49

\section{Chapter 4}

Peroxynitrite elaborated by hypercholesterolemia-induced neointima abrogates the protective action of vascular endothelial growth factor/vascular permeability factor on vascular endothelium. 63

\section{Chapter 5}

Vascular endothelial growth factor/vascular permeability factor prevents peroxynitrite-induced apoptosis in endothelial cells. 89

\section{Chapter 6}

General discussion 107

$\begin{array}{ll}\text { Summary } 115 & \\ \text { Samenvatting } 117 & \\ \text { Dankwoord } 119 & \\ \text { Curriculum vitae } & 121 \\ \text { Publicaties } 123 & \end{array}$




\section{Abbreviations}

\begin{tabular}{|c|c|}
\hline $\mathrm{ACh}$ & acetylcholine \\
\hline$A E C$ & 3-amino-9-erhylcarbazole \\
\hline ANOVA & analysis of variance \\
\hline Ao & thoracic aorta \\
\hline$B S A$ & bovine serum albumin \\
\hline CaM & calmodulin \\
\hline cDNA & Complementary DNA \\
\hline cGMP & cyclic GMP \\
\hline $\mathrm{Da}$ & Dalton \\
\hline DAB & $3,3^{\circ}$ diaminobenzide \\
\hline EC & endothelial cell \\
\hline EDRF & endothelium derived relaxing factor \\
\hline
\end{tabular}

FAD flavin adenine dinucleotide

FBS fetal bovine serum

FMN flavin mononucleotide

GAPDH glyceraldehyde phosphate dehydrogenase

GMP guanosine 3'-monophosphate

GTP guanoside 5'triphospate

$\mathrm{HC}$ high cholestoral diet

HIF hypoxia-induced soluble factor

HUVEC human umbilical vein endothelial cell

i- inducible-

IEL internal elastic lamina

IGF-1 insulin-like growth factor-1

IMA internal mammary artery

$I_{3} \quad$ inositol-tri-phosphate

IVC inferior vena cava

LDL low density lipoprotein

L-NAME $\quad \mathrm{N}^{(\omega)}$-nitro-L-arginine

L-NMMA $\mathrm{N}^{\mathrm{C}}$-monomethyl-L-arginine

MAPK mitogen-acrivared protein kinases

MCP-1 monocyte chemoattractant protein-1 


\begin{tabular}{|c|c|}
\hline NADP & nicorinamide-adenine-dinucleoride phosphate \\
\hline n-LDL & native LDL \\
\hline$n-N O S$ & neuronal NOS \\
\hline NE & norepinephrin \\
\hline $\mathrm{NF}-\mathrm{KB}$ & nuclear factor- $\kappa \mathrm{B}$ \\
\hline NGF & nerve growth factor \\
\hline $\mathrm{NO}$ & nitric oxide \\
\hline $\mathrm{NO}_{2}^{-}$ & nitrite \\
\hline $\mathrm{NO}_{3}^{-}$ & nitrate \\
\hline NOS & nitric oxide synthase \\
\hline NZWR & New Zealand white rabbit \\
\hline $\mathrm{O}_{2}^{-}$ & superoxide anion \\
\hline $\mathrm{ONOO}^{-}$ & peroxynitrite \\
\hline $\mathrm{ONOOH}$ & peroxynitrous acid \\
\hline ox & oxidized \\
\hline PA & pulmonary artery \\
\hline PBS & phosphare-buffered solution \\
\hline PDGF & platelet derived growth factor \\
\hline PI-3 & phosphatidylinostol-3" \\
\hline RAM & rabbit antibody macrophages \\
\hline rh- & recombinant human- \\
\hline RTK & receptor tyrosine kinases \\
\hline RT-PCR & reverse transcriptase-polymerase chain reaction \\
\hline$S A$ & surface area \\
\hline SNP & sodium nitroprusside \\
\hline SMC & smooth muscle cell \\
\hline SV & sapheneus vein \\
\hline $\mathrm{TdT}$ & terminal deoxynucleotidyl transferase \\
\hline TNF- $\alpha$ & tumor necrosis- $\alpha$ \\
\hline TUNEL & terminal deoxynucleotidyl transferase fluorescein nick end labeling \\
\hline VCAM-1 & vascular cell adhesion molecule- 1 \\
\hline VEGF & vascular endothelial growth factor \\
\hline VPF & vascular permeability factor \\
\hline WHHL & Waranabe heritable hyperlipidemic \\
\hline
\end{tabular}





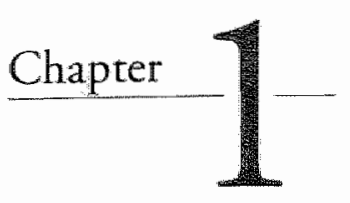

\section{Introduction}

The preservation of normal vascular anatomy and function over time has been shown to be crucial in mantaining tissue perfusion. It has been demonstrated that the endothellial cells play an important role in conserving vascular integrity. In this thesis the hypothesis will be tested whether a growth factor specific for endothelial cells can exert a maintenance/repair role on vascular endorhelium by augmenting the release of nitric oxide. Furthermore, additional studies on the aspects of this growth factor in a rabbit model of hypercholesteriolemia will be presented, especially with regard to the biochemistry of nitrogen oxides.

\section{Vascular endothelial growth factor/vascular permeability factor (VEGF/VPF)}

\section{VEGF/VPF-history}

In 1989 Gospodarowicz ${ }^{1}$ and Ferrara ${ }^{2}$ reported on a protein secreted by bovine pituitary folliculo-stellate cells, that caused mitogenic activity in vascular endothelial cells, but nor in other cell types tested, including epithelial, mesenchymal, or neuroectodermal cells or a variety of tumor cell lines. ${ }^{3}$ Because of the unique aspect of its narrow target cell. specificity, this mitogen has been named vascular endothelial growth factor (VEGF).

Also in 1989 Connolly ${ }^{4}$ and Senger ${ }^{5}$ identified a multifunctional protein secreted by tumor cells. Since it funcrioned as a potent and fast acting mediator of vascular permeability, ${ }^{6}$ it was named vascular permeability factor (VPF). VPF also has been documented as an endothelial cell specific growth factor ${ }^{1,2,7}$ and as an angiogenic agent in vivo. ${ }^{8}$ Analysis of receptor binding studies revealed two distinct classes of binding sites for this protein typically present on endothelial cells. ${ }^{9}$ Structural characterization and cDNA cloning of the involved factors revealed a single protein that hereafter will be referred to as VEGF/VPF.1,10 


\section{VEGF/VPF-structure}

VEGF/VPF is composed of two disulfide-ubidged subunits each with a molecular weight of approximately $23 \mathrm{kDa}$. Analysis of CDNA clones predicts the existence of $206-, 189-$, 165-, and 121-amino acid forms of the mature human VEGF/VPF subunit. 1,12,13 The mRNAs for these isoforms arise by alternative splicing from a gene composed of 8 exons. ${ }^{11}$ (figure 1) The alternative splicing involves exons 6 and 7 ; if neither exon is removed, $\mathrm{VEGF}_{\text {VPF }}$ 189 is generated; if only exon 6 is removed VEGF/VPF 165 is generated; and if both exons 6 and 7 are removed, VEGF/VPF 121 arises. Alternative splicing has profound effects on the behaviour of the translated proteins following secretion from the cell. The transcript of VEGF/VPF 165 , the most common form, contains an additional 44 codons relative to VEGF/VPF" 121 , resulting in a homodimeric protein of approximately $46 \mathrm{kDa}$. These additional 44 amino acids convert ir to a basic polypeptide with 7 cysteines nor found in the shortest form. These 7 cysteines gives the protein heparin binding capability. VEGF/VPF 165 was secreted in a stably transfected embryonic kidney cell line, and $70 \%$ appeared to bind to unidentified components on the cell surface or in the extracellular matrix. ${ }^{12}$ In contrast, the shortest form, VEGF/VPF ${ }_{121}$, is secreted and freely soluble. Lirtle or no VEGF/VPF 189 is found in a freely soluble form. The additional 24 -amino acid segment of this protein encoded by exon 6 is even more basic in nature, containing 12 lysine and arginine residues. $\mathrm{VEGE} / \mathrm{VPF}_{206}$ has an additional insertion of 17 amino acids. There is no intron berween exon 7 and the coding sequence for the additional 17 amino acid insertion found in VEGF/VPF 206 . It is a very rare form so far identified only in a human fetal liver CDNA library. ${ }^{13}$

It has been suggested that the unknown VEGE/VPF-binding sites in cell cultures involve a heparin containing proteoglycan. ${ }^{14}$ Interestingly, a variery of studies demonstrated that heparin-containing proteog]ycans are the constituents of the extracellular matrix that are responsible for binding and concentrating growth factors. with angiogenetic capacity. $15,16,17$

The intron-exon pattern of the gene and the conceptual translation of the exon sequences indicate a relation with the genes encoding the platelet-derived growth factor (PDGF) (Figure 1). ${ }^{1819}$ Dara base searches with the amino acid sequences reveal approximarely $21 \%$ and $24 \%$ homology respectively with both the mature forms of the $A$ and $B$ chains of human PDGF.20,21 Especially the locations of the seven cysteine residues involved in intra- and inter-molecular disulfide bridging are completely conserved among the sequences. ${ }^{10,22}$

Despite the structural similarities between VEGF/VPF and PDGE, the two proteins have very differenr biological activities. PDGF is an effective mitogen on cells of mesenchymal origin such as fibroblasts and vascular smooth muscle cells, whereas VEGF/VPF is active primarily on cells of vascular endothelial origin. 1,2.23 The different target cell specificity of VEGF/VPF implies that its action is mediated through distinct cell surface receptors. 


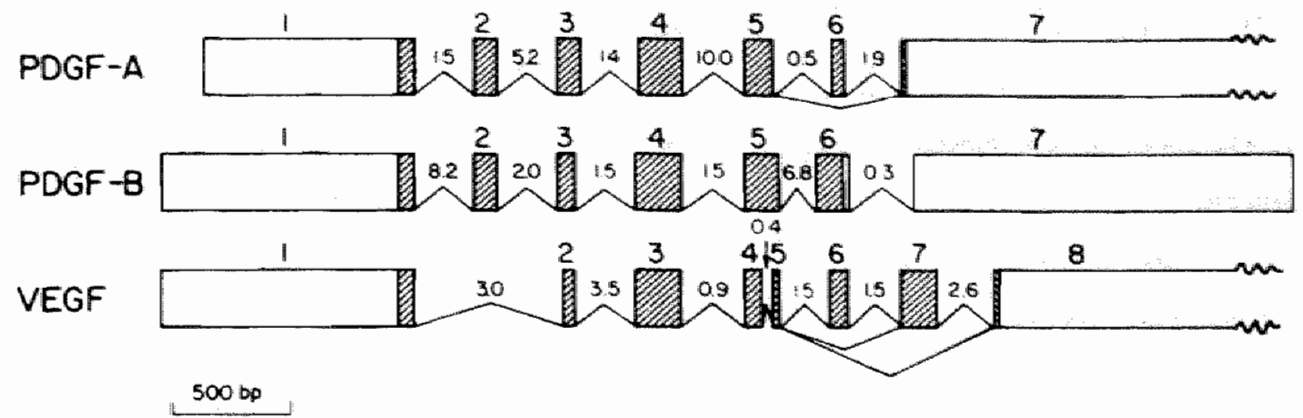

Figure 1. Comparison of the intron-exon structure of the VEGFIVPF gene with those of the PDGF A and $B$ chain genes. The number of each exon is given above each gene structure; coding regions are marked by diagonal lines and untranslated regions by open boxes. The precise lengths of the 3 -untranslated regions of PDGF $A$ and VEGF/VPF are not known. The numbers berween the exons refer to the size of each intron in kilobases. Both the normal and the alternative exon splicing pattems are shown. The scale refers to the exon sequences only. Figure from Tischer et al (ref. 11, with permission).

\section{VEGF/VPF-receptors}

In 1991 Terman and colleagues identified a new endothellial cell receptor tyrosine kinase gene, named $K D R^{24} K D R$ was identified from a human endorhelial cell cDNA library using primers homologous to the kinase domain of known receptor tyrosine kinases (RTK). The complete coding portion of KDR contains 4068 nucleotides and yields a 1356-amino acid residue protein. Marthews and colleagues reported the complete amino acid sequence of $F l k-1$, of which the strong sequence homology with the KDR-protein suggests that the two proteins are the human and mouse versions of the same gene. $25,26,27$ Seven immunoglobulin-like domains are present in the extracellular portion of the KDR protein, matching those of Flk-1. The mRNA for both receptors is selectively expressed in endorhelial cells, but not in other cell types in adult ${ }^{28}$ or in fetal ${ }^{29}$ rat tissues.

It has been reported that the fins-like tyrosine kinase $F l t-I$ is a VEGF-receptor also. ${ }^{30,31}$ Interestingly, KDR/Flk-1 and Flt- 1 share many structural similarities. Each is a RTK-unit with kinase inserts domains of similar length. Each contains seven immunoglobulin-like domains in the extracellular portion, and there is a degree of strucrural similarity between the two receptors in each domain. ${ }^{32}$ The mRNA for both receptors is selectively expressed in endothelial cells and quantitative autoradiographic analysis of whole-body rissue sections from the adult rat demonstrates that ${ }^{125} \mathrm{I}$-rhVEGF/VPF binds to these cells with high affinity in the $10-50 \mathrm{pM}$ range and low capacity. ${ }^{28}$ This binding is reversible and can be replaced by rhVEGF/VPF, but not by other growth factors. It is likely that high affinity binding identified in tissue sections reflects contribution of both Flk-1 and Flt 1 proteins. ${ }^{27.33}$ Because VEGF/VPF 165 is a heparin-binding protein, non-specific binding 
to proteoglycans was evaluated by adding an excess heparin, which did not significantly infuence specific (rhVEGF/VPF-displaceable) binding. Furthermore, excess of PDGF, which binds ro heparin as well, did not result in displacement either. ${ }^{28}$

Together with Flk-I/KDR and Flt-1, Flt-4 constitutes another member of a new subfamily of RTKs. ${ }^{34}, 35$. This receptor also contains seven immunoglobulin-like repeats. and is structurally closely related to $F / k-1$ and $F / t-1$. Interestingly, these similarities are also present between the $A$ and $B$ chains of the $P D G F$ receptor. ${ }^{36}$

More recently, new isoforms of VEGF/VPF, named VEGF/VPF-B and VEGF/VPF$\mathrm{C}$, have been isolated and cloned from a cDNA library prepared from the human prostatic adenocarcinoma cell line PC-3.37,38,39 For VEGF-C, it has been demonstrated that the protein is proteolytically processed, secreted to the cell culture medium, and bound to the extracellular domain of Flt-4 where it induces tyrosine autophosphorylation of Flt-4 and KDR. In addition, it has been shown that VEGF-C also stimulates migration of endothelial cells in collagen gels. Additional functional assays still are mandatory to assess the biological similarity of these highly related growth factors.

Since the earliest VEGF/VPF-binding sites were identified in the blood islands in the yolk sac, the expression of VEGF/VPF receptors may be one of the earliest events occurring in endothelial cell differentiacion. ${ }^{29.40}$ Consequently, VEGF/VPF may play an important role in the dewelopment of the vasculature of mammalian embryos. The tight temporal and spatial regulation of mRNA expression, documented by Breier ${ }^{41}$ and Jakeman, ${ }^{29}$ together with the ubiquitous nature of VEGF/VPF binding to endothelial and preendothelial cells are likely to serve the highly regulated development of the embryonic vascular system. Further support for this notion is the abnormal blood vessel development in transgenic mice embryos missing a single VEGF/VPF allele. 42 VEGF/VPF deficiency impairs most steps of early vascular development, including in situ differentiation of blood islands (vasculogenesis), sprouting from preexisting vessels (angiogenesis), lumen formation, the formation of large vessells, the establishment of interconnections, and the spatial otganization of intra- and extraembryonic vessels. Similar tesults were obtained in $F / k-I^{43}$ and $F / t-I^{44}$ deficient mice embryos.

Postnatally, expression of VEGF/VPF receptors by quiescent endothelium is reduced, ${ }^{33,45,46}$ or absent. ${ }^{47}$ Both the F/t-I and the KDR/FIk-I receptors have been shown to be upregulated only at sites of recurrent angiogenesis, such as in the corpora lutea of the ovary, 28,46 or in pathologic conditions as in psoriasis and tumor formation. $45,47,48$

VEGF/VPF itself is not capable of upregularing the expression of its receptors. 49 Interestingly, hypoxia has been shown to be a potent stimulus for augmented transcription of the VEGF/VPF gene in vascular endothelial cells in culture $50,51,52$ and in wiwo. ${ }^{53}$ In addition, it has been demonstrated both in vitro ${ }^{49.54}$ and in wivo, 55 that ischemic tissues produce hypoxia-induced soluble factors (HIFs), capable of upregulating $\mathrm{VEGF/VPF} \mathrm{receptor} \mathrm{expression} \mathrm{on} \mathrm{endothelial} \mathrm{cells.} \mathrm{Erythropoierin} \mathrm{is} \mathrm{another} \mathrm{example}$ of a protein that is upregulated under hypoxic conditions. An intriguing observation is 
the homology between a sequence in the VEGF/VPF promotor and a nucleotide sequence in the erythropoiecin promotor, identifed as a binding site for an HIF. 11,56

\section{VEGF/VPF-function}

The increased VEGF/VPF expression and the upregulation of its receptors under hypoxic conditions constitute a paracrine loop that stimulates endothelial cell mitogenesis, which is the initiating feature in angiogenesis. 57 For new blood vessel growth the activation of endothelial cells is followed by disruption of the basement membrane and subsequent migration of endothelial cells into the interstitial space in the direction of an ischemic stimulus. Intracellular vacuolar lumen formation, pericyte capping, and production of a new basement membrane complete the developmental sequence. ${ }^{57}$ This process is facilitated by VEGF/VPF-induced endorhelial cell secretion of serine proteases such as urokinase-type and tissuc-type plasminogen acrivators. ${ }^{58}$ In addition, VEGF/VPF increases the expression of matrix metalloproteinases, thus promoring a prodegradative environment that enables endorhelial cells to migrate. ${ }^{59}$ It has been shown that VEGF/VPF stimulates tumor growth by enhancing tumor angiogenesis in renal cell carcinoma, colon carcinoma and several intractanial tumors.60,61,62,63 A strong correlation has been reported between the degree of vascularization of the malignancy and VEGF mRNA expression. ${ }^{64}$ Consequently, monoclonal antibodies capable of inhibiting VEGF/VPF-induced angiogenesis in vivo exert a dramatic inhibitory effect on the growth of human sarcomas. ${ }^{63,65}$ Whether anti-VEGF/VPF therapy has therapeutical applicarions in highly vascularized tumors remains to be investigated.

VEGF/VPF mediated angiogenesis has been reported not only in hypoxic areas of tumors, but also in nonncoplastic ischemic conditions such as coronary artery disease, ${ }^{52,54}$ peripheral artery disease, ${ }^{66}$ and diabetes mellitus. ${ }^{54}$ VEGF/VPF therapy has been used to promote angiogenesis in conditions of insufficient tissue perfusion in a model of rabbit ischemic hindlimb, ${ }^{67,68,69}$ rat and rabbit cornea, ${ }^{7,70}$ the chorioallantoic membrane, ${ }^{2}$ and dog ischemic myocardium. 71 Currently, studies are performed to establish therapeutic angiogenesis in human peripheral artery disease following arterial gene transfer with a plasmid encoding the 165 amino-acid isoform of VEGF/NPF 72,73

Interestingly, perfusion through collateral circulation produces endothelial dysfunction in the recipient downstream microvessels as opposed to microvessels perfused by normal arterial circulation. ${ }^{74}$ It has been suggested that the collateral circulation fails to develop at a rate sufficiently rapid to prevent ischemic damage to endothelial cells of the downstream microvasculature. Expedited development of collaterals in response to administration of an angiogenic growth factor such as VEGF/VPF has been shown to markedly improve endothelium-dependent flow. ${ }^{75}$

A further potential therapeutical application of VEGF/VPF therapy is the prevention of restenosis following angioplasty. It has been proposed that damage to the endothelium is the crucial event triggering fibrocellular intimal thickening. ${ }^{76}$ Asahara and colleagues 
showed that local delivery of VEGF/VPF accelerated endorhelial cell mirogenesis and reendorhelialization and as a result attenuared intimal hyperplasia in balloon-injured rar carotid arteries. ${ }^{77}$ The specificity of VEGF/VPF for endothelial cells may be especially useful to avoid concomitant mitogenesis of vascular smooth muscle cells.

\section{Nirric oxide (NO)}

\section{NO-bistory}

In 1980 Furchgort and Zawadzki observed that vascular endothelium is mandatory in acerylcholine-induced relaxation of smooth muscle cells. ${ }^{78}$ The involved endotheliumdependent relaxing factor (EDRF) has been shown to be the free radical nitric oxide (NO). ${ }^{70,80,81} \mathrm{NO}$ is a gas that is poorly soluble in water. It has a short half-life of approximately 10 to 60 seconds in tissue, because it readily reacts with oxygen, superoxide radicals, and transition metals such as iron and copper ${ }^{82,83}$ Consequently, NO does not function as a hotmone since oxyhemoglobin rapidly combines with NO to yield methemoglobin and nitrate $\left(\mathrm{NO}_{3}{ }^{-}\right){ }^{84}$ However, $\mathrm{NO}$ is particularly useful as an intracellular messenger because it can easily diffuse through most cells and tissues. ${ }^{85}$

\section{NO-chemistry}

$\mathrm{NO}$ is generated from the terminal guanidino-nitrogen of L-arginine by an $\mathrm{N}^{(1)}$-hydroxylL-arginine intermediate yielding citrulline. This reaction is catalyzed by a nitric oxide synthase (NOS):

L-arginine $+\mathrm{nNADPH}+\mathrm{mO}_{2} \rightarrow$ citrulline $+\mathrm{NO}+\mathrm{nNADP}^{+}$.

"Three different isoforms of NOS have been documented so far, based on three different genes that have been cloned and sequenced: two isoforms of constitutive NOS present in vascular endothelial cells (ec-NOS) or in brain tissue (neuronal NOS, n-NOS), and one isoform of inducible NOS (i-NOS). These isoforms differ in cell and organ localization and in sensitivity to calcium stimulation. ${ }^{86}$ NOS proteins share approximately $50 \%$ amino acid sequence identity each. Within each isoform group (ec-NOS, n-NOS, i-NOS), there is a high degree of amino acid identity across species $(80-94 \%) .{ }^{87}$ The human ec-NOS contains 1,203 amino acids. A schematic representation of the amino acid sequences is shown in figure 2. Comparison of the deduced amino acid sequences from the three isoforms of NOS demonstrates that the greatest similarity in structure is found in the last two-thirds of the molecule, the carboxyl terminal. The amino terminal is unique for each isoform and contains sites for potential postrranslational modification. 88

All isoforms require four co-factors: flavin mononucleoride (FMN), flavin adenine dinucleoride (FAD), iron-protoporphyrin IX (heme), and tetrahydrobioprerin. 


\section{Neuronal NOS}

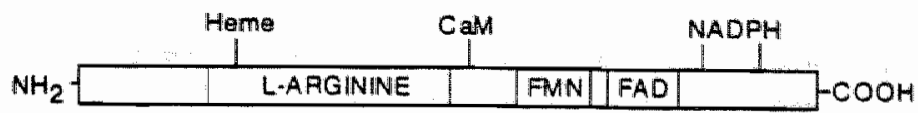

\section{Cytokine-inducible NOS}

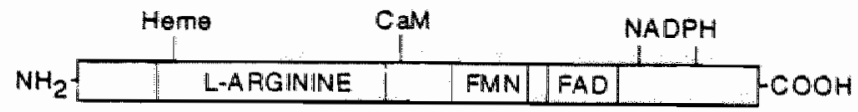

\section{Endothelial NOS}

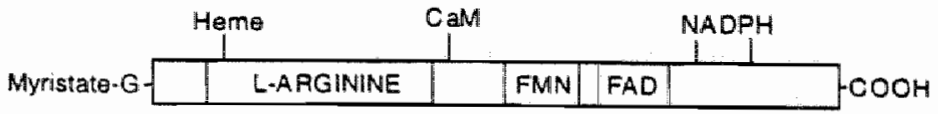

Figure 2. Schematic representation of the three different isoforms of nitric oxide synthase (NOS). Neuronal NOS contains an additional amino acid seguence with unknown function. The amino reminal of ec-NOS has been myristoylated, which is mandatory for mernbrane atrachment. CaM: calmodulin; other abbreviations: see text.

Furthermore, nicotinamide-adenine-dinucleotide phosphate (NADPH) is mandatory for NOS activity and therefore has been used to determine NOS capacity.

The two isoforms of constitutive NOS (ec-NOS, n-NOS) are calcium and calmodulin dependent and continuously generate small quantities of NO. A variety of agents capable of increasing intracellular free calcium such as acetylcholine and bradykinin have been shown to cause acrivarion of ec-NOS, which subsequenty leads to endothelium-dependent vasorelaxation. ${ }^{89} \mathrm{NO}$ synthesis in vascular endothelial cells is regulated by two known mechanisms. Acrivation of NOS is dependent on the intracellular free calcium concentration and the rate of L-arginine transport into endothelial cells. ${ }^{\text {} 0}$ Although ec-NOS activity is inhibited by high doses of exogenous $\mathrm{NO}$ (NO donors), it has been shown not to be sensitive to feedback inhibition by endogenous $\mathrm{NO}$ production. 1

The N-terminal region of the ec-NOS protein contains a unique sequence for attachment of myristic acid. This $\mathrm{N}$-myristoylation allows this enzyme to attach to a specific membrane site. ${ }^{22}$ Consequently, only membrane-bound ec-NOS has been shown to be activated by modulations of flow conditions: shear stress-induced endothelial NO release represents a highly effective and sensitive system for local control of vascular tone. ${ }^{93.94}$

The NO synthesizing enzyme in macrophages is referred to as $\mathrm{I}-\mathrm{NOS}$ and is capable of producing nanomolar quantities NO throughout the life of the enzyme, which is approximately 1.000 -fold more than rhe constiturive production by ec-NOS. Calmodulin 
is bound tightly to $\mathrm{i}-\mathrm{NOS}$, but the enzyme is not sensitive to fluctuations in intracellular free calcium concentrations. ${ }^{95,96}$ In quiescent conditions $\mathrm{i}-\mathrm{NOS}$ is not expressed in leukocytes, but it can be induced in several different cell types by cytokines such as interleukin-1 $\beta$, tumor necrosis factor- $\alpha$ (TNF- $\alpha$ ), and interferon- $\tau$ as well as by bacterial lipopolysaccharides. ${ }^{97}$ The induction of $\mathrm{i}-\mathrm{NOS}$ is responsible for the $\mathrm{NO}$-mediated cytotoxic properties of macrophages. ${ }^{98}$ In rabbits, 30 minutes after administration of lipopolysaccharides an NO-related decrease in blood pressure has been observed, reflecting the time necessary for i-NOS to become expressed. ${ }^{99}$ Its induction is inhibited by glucocorticoids, which explains the beneficial action of these type of agents in the treacment of septic shock. ${ }^{100}$ It has been observed that a combination of cytokines and endotoxins exerts a synergistic action in cytotoxicity, which possibly reflects a primordial, but effective mechanism for microcidal activity of macrophages. 101

\section{NO-function}

Of the known 92 naturally occurring elements in the universe 6 are present in all living creatures and are indispensible to life as we know it on this planer, including nitrogen and oxygen. ${ }^{102}$ The simple molecule NO has been incorporated from the early occurrence of life, which might be an explanation for the great number of phenomena that are mediated by this free radical gas, including endothelium-dependent vascular relaxation, 80 but porentially also cardiac and skeletal muscle relaxation, ${ }^{103}$ endothelial permeability, macrophage-mediated cytotoxicity, ${ }^{104}$ inhibition of platelet adhesion and aggregation, ${ }^{105,106}$ inhibition of leukocyte adhesion, ${ }^{107}$ DNA modifications and repair, transcriptional regulation, ${ }^{108}$ tissue injury and inflammation, hormone production and secretion, relaxation of the human penile corpus cavernosum, ${ }^{109}$ regulation of basal blood pressure, ${ }^{110}$ long-term potentiation of synaptic transmission, 111 glomerular and medullary microcirculation, ${ }^{112}$ ventilation-perfusion matching, ${ }^{113}$ intestinal secretion and ion transport, including prevention of pylorospasm in infantile hypertrophic pyloric stenosis. ${ }^{114}$

NO reacts with a variery of low and high molecular weight molecules, such as guanylyl cyclase, cyclic nucleotide protein kinases and phosphodiesterases, cyclooxygenase, heme proteins, and phopholipase C. ${ }^{103}$ The NO generated in endothelial cells binds to the heme component of soluble guanylyl cyclase-guanosine 5'-triphosphate (GTP)-complex located in adjacent smooth muscle cells. Nitrosation by NO dislocates the heme-iron out of the plane of the porphyrin ring, which acrivates the catalytic site of guanylyl cyclase, resulting in an increase of cyclic guanosine 3'-monophosphate (cGMP) production. The intracellular concentration of CGMP is determined by the rate of formation and hydrolysis of cGMP by the type $V$ isoenzyme of cyclic $3^{\prime}, 5^{\prime}$-nucleotide phosphodiesterases. 115 The mechanism by which cGMP produces vasorelaxation is not entirely clear. It has been suggested that vasorelaxation is mediated by a cGMP-dependent protein kinase causing 
activation of $\mathrm{Ca}^{2+}$-dependent $\mathrm{K}^{+}$channels. ${ }^{116.117}$ Other groups proposed that $\mathrm{CGMP}$ impairs angiotensin II activity in mesangial cells, thus promoting vasorelaxation. ${ }^{118}$

Recently, it has been reported that cGMP-elevating agents suppress proliferation of vascular smooth muscle cells. ${ }^{19}$ Experiments conducted by several groups have elucidated growth factor-related signaling pathways to mitogenesis of vascular smooth muscle cells. Cytokines and several growth factors such as fibroblast growth factor (FGF), platelet derived growth factor-AB (PDGF-AB), and epithelial growth factor (EGF) have been described to contribure to growth of vascular smooth muscle cells in injured blood vessels. These growth factors stimulate the synthesis of DNA and cell proliferacion by activaring the phosphorylarion cascade of mitogen-acrivated protein kinases (MAPK). ${ }^{20}$ "This activation initiates the cell cycle transition via phophorylation of nuclear transcription factors of genes such as $c$-for, $c-j w n$, and $c-m y c{ }^{121}$ It has been reported that interleukin-1 $\beta$ acts synergistically with these growth factors to promote smooth muscle cell mitogenesis. ${ }^{122}$ Inhibitors of NOS did not block this co-mitogenic effect, suggesting that this synergism is independent of the NO/cGMP pathway.

Vascular endothelial growth factor/vascular permeability factor (VEGF/VPF) has been shown to act exclusively on endorhelial cells and to be capable of augmenting endothelial cell NO release (this thesis). So far, no evidence has been provided that VEGF/VPF promotes vascular smooth muscle cell mitogenesis via the NO/cGMP pathway. Support for this notion is found in the observation that during differentiation of neuronal cells nitric oxide triggers a switch to growth arrest rather than to cell proliferation. ${ }^{123}$. In addition, it has been postulated that $\mathrm{NO}$ is involved in the control of vascular smooth muscle cell apoptosis. ${ }^{24} \mathrm{NO}$ is capable of inducing smooth muscle cell apoptosis, thus contributing to tissue homeostasis in the media of the vessel. Some controversy exists whether programmed cel death is mediated directly by $\mathrm{NO}^{125}$ or via the $\mathrm{NO} / \mathrm{cGMP}$ pathway. 126

\section{NO-oxidative stress}

The production of free radicals has been associated with oxidative stress-related tissue injury. A major mechanism in the generation of oxidative stress in atherosclerosis is associated with the production of $\mathrm{NO}$ in vivo and its reaction with the superoxide atnion $\left(\mathrm{O}_{2}{ }^{-}\right)$to form peroxynitrite:

$\mathrm{NO}+\mathrm{O}_{2}^{-} \rightarrow \mathrm{ONOO}^{-127}$

The direct toxiciry of $\mathrm{NO}$ is relatively low, but greatly enhanced by the formation of peroxynitrite. ${ }^{127}$ Peroxynitrite is a strong oxidant that can react with a number of biological molecules. Nitration of structural proteins, for example, mostly has major pathological consequences. ${ }^{128}$ It has been observed that myocyte depression associated with NO production is due to nitration of the contractile proteins. ${ }^{129}$ Normally, the concentration of superoxide is kept low by natural scavengers such as superoxide 
dismutase, although a large flux of superoxide is produced by aerobic metabolism. 130 However, the reacrion ratc for the formation of peroxynitrite has been determined to be $6.7 \pm 0.9 .10^{9} \mathrm{M}^{-1} \cdot \mathrm{s}^{-1}$, which is approximately six times faster than the scavenging of superoxide with copper or zinc superoxide dismutase at physiological conditions. 131 Consequently, $\mathbb{N O}$ is the only known biological molecule produced in high enough concentrations under pathological conditions to outcompete endogenous superoxide dismutase for superoxide. In atherosclerotic lesions the production of both $\mathrm{O}_{2}^{-132}$ and NO (this thesis) is significantly increased, culminating in a sharp increase in oxidative stress employed by the production of peroxynitrite.

One of the most important sources of a pathological increase in NO are lipid-laden foam cells in the subendothelial space. The recruirment of monocytes into the arterial wall bas been shown to be one of the earliest events in the parhogenesis of atherosclerosis. 133 The mechanism whereby lipoproteins are initialy oxidized has never been proven, but Graham ${ }^{134}$ and colleagues have shown that peroxynitrite modifies low-density lipoproteins into a form recognized by the macrophage scavenger receptor. Experimental studies in animal models of atherosclerosis have demonstrated that these cells accumulate subendothelially after artachment to the arterial endothelium. 135 Cytokine-induced oxidative stress is an important regulatory signal in endothelial cells that mediates the expression of vascular cell adhesion molecule-1, which is a crucial initiaring event in the development of atherosclerosis. ${ }^{136}$ Subsequent penetration of the endothelial layer presumably occurs in response to chemotactic factors such as monocyte chemoatractant protein $1(\mathrm{MCP}-1)$ released from cells in the vascular wall. 137 Once accumulated in the subendothelial space, macrophages start to ingest oxidized lipoproteins and become foam cells. In time, these nests of foam cells lead to proliferation of smooth muscle cells, the deposition of increased extracellular matrix, the formation of extracellular pools of lipid, and the development of necrotic foci to form intermediate lesions. Eventually, the development of fibrous plaques occurs, which ultimately produces the clinical manifestations of atherosclerosis. 138

\section{NO-medsuements}

A wariety of techniques have been previously employed to measure NO. NO production has been studied using a chemiluminescence assay; ${ }^{139}$ this approach measures the intensity of thorescent radiation emitted afrer oxidation of $\mathrm{NO}$ by ozone. The use of this method for measurement of $\mathrm{NO}$ production in an aqueous solurion first requires reduction of $\mathrm{NO}_{2}$ - back to $\mathrm{NO}$, and second transfer of $\mathrm{NO}$ from solution to gas. A limitation of this technique is that removal of NO from solution may introduce significant error at lower concentrations.

Kiechle and Malinski reported an electrochemical method, based on registration of curtent, secondary to oxidation of NO. ${ }^{139}$ This technique permits measurements to be made within short time intervals on the surface of the cell membrane, using 
electrochemical sensors with a diameter between 0.2 and $1.0 \mu \mathrm{m}$. The size of the sensor, however, restricts its use to measurements of NO release from cells, and is not applicable for NO registration from intact tissue specimens.

In the current studies, we therefore employed an alrernative method, UV-visible spectrophotometry, which is relatively easy to perform, yields reproducible results, and allows measurements of significant differences of $\mathrm{NO}$ concentrations in the micromolar range from intact vascular segments. This approach will be discussed in derail in the Methods-section of chapter 2 .

\section{Hypothesis}

The function of VEGF/VPF on quiescent endothelial cells remains enigmatic. It has been thought that VEGF/VPF receprors are importantly downregulated in mature endothelium. ${ }^{33.48}$ However, Peters and colleagues observed expression of Flt-1 mRNA by quiescent endothelium of the adult mouse in multiple organs, including brain, ${ }^{4}$ corresponding to a similar pattern of ${ }^{125}$-VEGF binding described earlier by Jakeman and colleagues; ${ }^{29}$ these studies thus suggested that VEGF/VPF, produced by vascular smooth muscle cells, macrophages, fibroblasts or other cell types in the vessel wall, might have a function in mature vessels other than mediating vascular growth, such as conserving the integrity of the endothelial layer in mature blood vessels.

NO has been implicated as a key molecule involved in the regulating function of vascular endothelium and, consequently, the prevention of intimal thickening responsible for compromised atterial patency. ${ }^{141,142} \mathrm{VEGF} / \mathrm{VPF}$, too, has been shown to inhibit intimal thickening in rat and rabbit models of balloon-injured arteries. 7.143 The results of these animall studies suggest that $\mathrm{NO}$ is at least in part responsible for mediating this inhibitory effect of VEGF/VPF on intimal thickening.

Defective endothelial function thas been shown to have a permissive impact on intimal thickening. This inverse relation is attribured to the loss of certain NO-mediared putative endothelial functions, including barrier regulation of permeability, thrombogenicity, leukocyte adherence, and producrion of growth-inhibitory molecules. Interestingly, it has been observed that aging, an important determinant of vascular disease, specifically is associated with reduced concentrations of endothelial $\mathrm{NO}$ release. ${ }^{144} \mathrm{Also}$, in the human coronary circulation, it was observed that despite the absence of angiographic evidence of atherosclerosis, exposure to risk factors was associated with reduced bioavailability of $\mathrm{NO} \cdot 145$

We thus hypothesized that

a. functional VEGF/VPF-receptors are present on quicscent endothelial cells of mature blood vessels harvested from different regions and from different adult species;

b. VEGF/VPF has a maintenance/repair role serving the integrity of the endothelial layer.

c. that VEGF/VPF increases the bioavailability of $\mathrm{NO}$; 
d. the formation of peroxynitrite is associated with reduced bioavailability of endothelial $\mathrm{NO}$ and the occurrence of apoptosis; and

e. VEGF/VPF protects endothelial cells, but not other cell types, from oxidarive stress-induced apoptosis.

\section{This thesis}

Data supporting these hypotheses will be provided in chapter 2 and 3 , where functional VEGF/VPF receptors on quiescent endothelium of rabbit and human blood vessels are shown to be involved in augmenting endothelial cell nitric oxide release. This observation supports the theory that some of the known effects of VEGF/VPF may reflect restored or enhanced $\mathrm{NO}$ production.

In chapter 4 data are presented supporting the hypothesis that VEGF/VPF exerts a maintenance role on vascular endothelial cells in a rabbit model of hypercholesterolemia. VEGF/VPF preserves endothelial function as evidenced by the induction of normal NO-mediated vasomotor responses. However, after the occurrence of neointima formation, this beneficial effect of VEGF/VPF on endothelium is shown to be lost. Oxidative stress implemented by the generation of peroxynitrite in the neointima results in reduced bioavailability of NO.

Although the conserving effect of VEGF/VPF on endothelial function will be lost in hypercholesterolemia-induced intimal thickening, in chapter 5 it will be demonstrated that VEGF/VPF does protect endothelial cells from peroxynitrite-induced apoptosis. Because of the narrow target specificity of VEGF/VPF, apoprosis of other intimal cells is not affected. The result is a reduced cellularity of the neointima, which may serve increased vascular patency.

\section{References}

1. Gospodarowicz D. Mbraham JA, Schilling J. Isolarion and characterization of a wascular endothelial cel mitogen produced by pituitary derived folliculo stellate cells. Proc Nar Aad Sei US A 1989;86:73117315

2. Farrara $N$, Henzel. WJ. Pituikary follicular cells secrete a nowel heparin-binding growth factor specific for vascular cadothclial cells. Brochem Biophys Res Commton 1989;161:851-857

3. Mouer I. Schilling, Gospodarowitz D. Isolation and characterization of a newly identified endothelial cell mirogen produced by ArT20 cells. EMBO / 1989;8:3801 -3807

4. Connoly DT. Olander JV. Heuvelman D, Nelson R, Monsell R, Siegel N, Haymore BL, Leimgruber R, Feder J. Human vasculat permeabilicy factor. Isolacion from 4937 cells. I Biol Cbem 1989:264:20017-20024

5. Senger DR, Connolly DT, Vande Water L, Feder J, Dvorak HF. Purification and $\mathrm{NH}_{2}$-terminal amino ated sequence of guinea pig rumor-secrered vascular permeability factor. Cancer Res 1990;50;17741778 
6. Senger DR, Galli SJ, Dvorak AM, Perruzzi CA, Harvey VS, Dworak HF. Tumor cells secrete a vascular permeability factor that promores accumulation of ascites fluid. Science (Wash DC) $1983,219,983-985$

7. Connolly DT, Hewwelman DM, Nelson R, Olander JV, Eppley BL, Delfino JJ, Siegel NR, Leimpruber [RM, Feder ]. Tumor vascular permeability factor srimulates endothelial cell growth and angiogenesis. JClin Invest 1989;84:1470-1478

8. Leung DW, Cachianes G, Kuang W-J, Goeddel DV, Ferrara N. Vascular endotheliat groweth factor is a secreted angiogenic mitogen. Science 1989;246:1309-1312

9. Olander JV, Connolly DT, DeLarco IE. Specific binding of wascular permeability factor to endorhelial cells. Biochem Biophys Res Commun 1991;175:68-76

10. Keck PJ, Hauser SD "Krivi G, Sanzo K, Warren T, Feder J, Connolly DT. Vascular permeability Gactor, an endothelial cell micogen relared ro PDGF. Skience 1989;246:1309-1312

11. Tischer E, Mirchell R, Hartman T, Silva M, Gospodarowicz D, Fiddes JC, Abraham JA. The human gene for vascular endorhelial growth factor. Mulciple protein forms are encoded through alternative exon splicing. J Biol Chem 1991;266:11947-11954

12. Houck KA, Leung DW, Rowland AM, Winer J. Ferrara N. Dual regulation of vascular endothelial growth factor bioawailability by genetic and proteolytic mechanisms. J Biol Chem 1992;267:2603126037

13. Houck KA, Ferrara N, Winer J, Leung DW. The vascular endothelial growth facror family: identification of a fourth molecular species and characturizarion of alternative splicing of RNA. Mol Endocrinol 1991:5:1806-18:13

14. Sakscla O, Rifkin DB. Release of basic fibroblast grown factor-heparan sulfite complexes from endorhelial cells by plasminogen acrivaror-mediared proteolyric activity./ Cell Bio/ 1990;1 10:767-775

15. Yayon A, Klagsbrun M, Esko JD, Leder P, Onitz DM. Cell surface, heparin-like molecules are required for binding of basic fibroblasr growth factor to its high affinity receptors. Cell 199:64:841-848

1.6. Roberts R, Gallagher J, Spooncer E Allen TD, Bloomfield F. Dexter TM. Heparan sulphate bound growh factors: a mechanism for stromal cell mediated haemapoiesis. Nature 1988;332:376 378

17. Gitay-Goren $H$, Soker S, Vlodavsky 1, Neufeld. G. The binding of vascular endothelial growth facror to its receptors is dependent on cell surface-associated heparin-like molecules. If Bül Chem $1992 ; 267: 6093-6098$

18. Rorsman F, Betsholtz C. Characterization of the mouse PDGF A-gene. Evolutionary conservation of gene structure, nucleotide sequence and alternative splicing. Grotwh Factors 1992;6:303-313

19. Pollock RA, Richardson WD. The alternative-spliced isoforms of the PDGF A-chain differ in their ability to associate with the extracellular matrix to bind heparin in witro. Growth Factors 1992;7:267-277

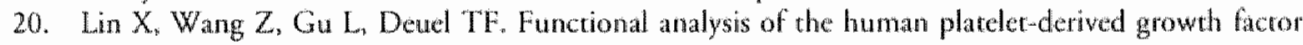
A-chain promotor region. / Biol Chem 1992;267:25614-25619

21. Tischer E, Gospodarowice D, Mitchell R, Silva M, Schilling J, Lau K, Crisp T. Fiddes JC, Abratham IA. Vascular endothelial growth factor: a new member of the plarelet-deriwed growth factor family. Biochem Biophys Res Commun 1989;165:1198-1206

22. Giese NA, Robbins $\mathrm{KC}$. Aaronson $\mathrm{SA}$. The role of individual cystein residues in the structure and function of the $\psi-5 i$ gene product. Science 1987;236:1315-1318

23. Nicosia RF, Nicosia SV, Smith M. Vascular endathelial growth factor, platelet-derived growtly facror, and insulin-like growth factor-1 promore rar aorric angiogenesis in virro. Am J Pathol 1994:145:10231029

24. Terman BI, Dougher-Vermazen M, Carrion ME, Dimatrow D, Armellino DC, Gospodarowica D, Böhlen P. Identification of the KDR tyrosine kinase as a receptor for vascular endothelial cell growth factor. Biachem Biophys Res Commun 1992;187:1579-1586

25. Mathews W, Jordan CT, Gavin M, Jenkins NA, Copeland NG, Lemischka IR. A recepror yyrosine kinase CDNA isolated from a population of enriched primitive hematopoictic cells and exhibiting close genetic linkage to c-kit. Proc Notl Acad Sci U S A 1991:88:9026-9030

26. Neufeld G, Tessler S, Gitay-Goren H, Cohen T, Lewi BZ. Vascular endorhelial growth factor and its receprors. Prog Growth Factor Res 1994:5:89-97 
27. Quini TP, Peters KG, De Vhes C, Ferrara N, Willams LT. Fetal diver kinase 1 is a receptor for vascular endothetial growth factor and is selecrively expressed in wascular endothelium. Proc Nal Acad Soi US A $1993 ; 90: 75337537$

28. Jakeman LB, Winet J, Benner GL, Alar CA, Ferrara N. Binding sires for vascular endothelial growth factor are localized on endotacial cells in adult rat rissues. J Clin lowest 1992;89:244-253

29. Jakeman $1 B$, Armanin M, Phillips HS, Ferrara N. Developmental expression of binding sites and messenger ribonudeic acid for vascular endothelial growth factor suggeses a role for this prorein in vabulogenesis and angiogenesis. Endocrinology 1903;133:848-859

30. Shibuya $M$, Yamaguchi S, Yamane A, Ikeda T, Tojo $A$, Marsushime H, Sato M. Nudeotide sequence and expression of a novel human receptor-rype ryrosine kinase gene $(f t)$ closely relared to the fons farmily. Oncogene 1990.5 .519 .524

31. De Vries C, Escobedo JA, Ueno H, Houck K, Ferrara $N$, Williams LT. The fms-like tyrosine kinase, a receptor for vascular endohelial growh facror. Science 1992;255:989-991

32. Keyr BA, Nguyen HV, Berleau LT, Duarte CM, Park J, Chen H, Ferara N. Identification of vascular endothelial growth factor determinants for binding KDR and Flr 1 receprors. Generation of receprorselecrive VEGF variants by site-directed muagenesis. J Biol Chem 1996;271:5638-5646

33. Millauer B, Wizigman-Voos S, Schnurch H, Martinez R, Moller NPH, Risau W, Ulrich A. High alfinity VEGF binding and developmental expression suggests FLK-I as a major regularor of vasculogenesis and angiogeriesis. Cell 1993;72:835-846

34. Aprelikowa O. Pajusola K, Partanen J, Armstrong E, Alitalo R, Bailey SK, McMahon J, Wasmurh J, Huebner K. Alitalo K. FLT4, a novel class III receptor tyrosine kinase in chromosome 5 q33-qter. Cancer Res $1992,52: 746-748$

35. Galland F, Karamysheva A, Mattei M-G. Rosner O, Marchetto S, Birnbaum D. Chromosomal Iocalization of FLT4, a novel receptor-type ryrosine kinase gene. Genomics 1992;13:475-478

36. Westermark B, Siegbahn A, Heldin CH, Claesson-Welsh L. B-type receptor for platelet-derived growth factor mediates a chemotactic response by means of ligand-induced activation of the receptor proteintyrosine kinase. Proc Natl Acad Sci U SA 1990;87:128-132

37. Joukov V, Pajusola K, Kaipainen A, Chilov D, Lahrinene I, Kulkk E, Saksela O, Kalkkinen N, Aliralo K. A novel wascular endorhelial growth factor, VEGF-C, is a ligand for the Flt4 (VEGFR-3) and KDR (VEGFR-2) receptor tyrosine kinase. EMBO / 1996;15:290-298

38. Olofson B, Pajusola K, Kaipainen A, Von Eular G, Joukov V, Saksela O, Orpana A, Petterson RF, Alitalo K, Eriksson U. Vascular endothelial growth factor B, a novel growth factor for endothelial cells. Proc Nath Acad So US A 1996;93:2576-2581

39. Parvonen K, Horelli-Kuirunen N, Chilov D, Kukk E, Permanen S, Kallioniemi OP, Pajusola K, Olofson B, Eriksson U, Joukov V. Palotie A, Alitalo K. Novel human vascular endothelial growth factor genes VEGF-B and VEGF-C localize to chromosomes $11 \mathrm{q} 13$ and 4q34, respectively. Circulation $1.996: 93: 1079-1082$

40. Yantuguchi TP. Dumont DJ, Conlon RA, Breirman ML, Rossanr J. Flk-1, an ft-relared receptor ryrosine kinase is an early marker for endothelial cell precursors. Development 1993:118:489-498

41. Breier $\mathrm{G}_{*}$ Abreche U, Sterer S, Risau W. Expression of watscular endothelial growth factor during embryonic angiogenesis and endothelial cell differentiation. Development 1992;114:521-532

42. Camelice $\mathbb{P}$, Fereira V, Breicr G, Pollefeye S, Kieckens L, Gertsenstein M, Fahrig M, Vandenhoeck A. Harpal K, Erberhardr C, Declerq C, Pawling J, Moons L, Collen D, Risau W, Nagy A. Abrormal blowd vessel development and lethality in embryos lacking a single VEGF allele. Nanure 1996;380:435439

43. Shalaby F, Rossant J, Yamaguchi TP, Gersenstein M, Wu XF, Breitman ML, Schuh AC. Failure of blood-island formation and vasculogenesis in Flk-l-deficient mice. Nature 1995;376:62-66

44. Fong GH, Rossant J, Gertsenstein M, Breitman ML. Role of the Flt-l receptor tyrosine kinase in regulating the assembly of vascular endothelium. Nature 1995;376:66-70 
45. Dermar M, Brown LF, Claffey KP, Yeo K-T, Kocher O. Jackman RW, Berse B, Dvorak HE. Overexpression of vascular permeability factor/vascular endothelial growth factor and is receptors in psoriasis. J Exp Med 1994;180:1141-1146

46. Shweiki D, Irin A, Gitay-Goren H, Keshet E. Parterns of expression of vascular endothelial grow h factor (VEGF) and VEGF receptors in mice suggesr a role in hormonally regulated angiogenesis. $/ \mathrm{CH}$ Intwest 1993;91:2235-2243

47. Brown LF, Berse B, Jackman RW, Tognazza K, Guidi AJ, Dvorak HF, Senger DR, Conolly IL, Schnirt SJ. Expression of vascular permeabiliry facror (vascular endorhelial groweh factor) and its receptors in breast cancer. Human Pathol 1995;26:86-91

48. Plate KH, Breier G, Weich HA, Mennel HD, Risau W. Vascular endothelial growrh factor and glioma angiogenesis: coordinate induction of VEGF receptors. Distribution of VEGF protein and possilale in vivo regulatory mechanisms. Int / Cancer 1994;59:520-529

49. Brogi E, Schatteman G, Wu T, Kim EA, Varcicovski L, Key B, Isner \M. Hypoxia-induced paracrine regularion of vascular endothelial growth factor receptor expression. / Clin Invest 1996:97:469-476

50. Namiki A, Brogi E, Kearney M, Kim EA, Wu T, Couffinhal T, Varticovski L, Isner JM. Hypoxia induces vascular endorheliall growth faccor in cultured human endothelial cells. I Biol Cbem $1995: 270: 31189-31195$

51. Liu Y, Cox SR, Morita T, Kourembanas S. Hypoxia regulates vascular endorhelial growth factor gene expression in endothelial cells. Idencification of a 5 ' enhancer. Cir Rer 1.995:77:638-643

52. Levy AP, Levy NS, Wegner S, Goldberg MA. Transcriprional regulation of the rat vascular endothelial growth factor gene by hypoxia. J Brol Chem 1995;270:13333-13340

53. Hashimoto E, Ogira T, Nakaoka T, Matsuoka R, Takao A, Kira Y. Rapid inducrion of vascular endothelial growth factor expression by transtent ischemia in rat heart. Am J Physiol 1994:267: H1948H1954

54. Takagi H, King GL, Ferrara N, Aiello LP. Hypoxia regulates vascular endothelial growth factor receptor KDR/FLK gene expression through adenosine A2 receptors in retinal capillary endorhelial cells. 7 west Ophtalmol Vis Sci 1996:37:1311-1321

55. Li J, Brown LF, Hibberd MG, Grossman JD, Morgan JP, Simons M. VEGF, flk 1 , and flk 1 expression in a rat myocardial infarction model of angiogenesis. Am / Pbysicol 1996:270:H1803-H1 811

56. Wang GL, Semenza GL. Characterization of hypoxia-inducible facror 1 and regulation of DNA binding activity by hypoxia. Blood 1993;268:21513-21518

57. D'Amore PA, Thompson RW. Mechanisms of angiogenesis. Annu Rev Physiol 1987;49:453-464

58. Pepper MS, Ferrara N, Orei L. Montesano R. Vascular endothelial growh factor (VEGI') induces plasminogen acrivators and plasminiogen activaton inhibitor type in microvascular endothelial cells. Biochem Biophys Res Commun 1991;181:902-908

59. Unemori E, Ferrara N, Bauer EA, Amento EP. Vascular endothelial growth factor ind uces interstitial collagenase expression in human endorhelial cells. / Cell Pbysiol 1992;153:557.562

60. Berse B, Brown LF, Van de Vater L, Dvorak HF, Senger DR. The vascular permeability factor (wascular endorhelial growth factor) gene is differentially expressed in nomal tissues, macroplages and curnors. Mol Biol Cell 1992;3:2』1-220

61. Shweiki D, Itin A, Soffer D, Keshet E. Vascular endothelial growth factor induced by hypoxia may mediate hypoxia-initiated angiogenesis. Natwre 1992,359:843-845

62. Plate KH. Breier $G$, Weich HA, Risau W. Vascular endothelial growth is a potential tumour angiogenesis factor in vivo. Nature 1992;359:845-847

63. Kondo S, Asano M, Suzuki H. Significance of vascular endorhelial growth factor/vascular permeability factor for solid rumor growth, and its inhibition by the antibody. Biochem Bophys Res Canmon 1993:194:1234-1241

64. Berkman RA, Merrill M], Reinhold WC, Monacci WT, Saxena A, Clark WC, Robertson JT, Ali [U, Oldfield $\mathrm{EH}$. Expression of the wascular permeabiliry/vascultar endothelial growth factor gene in central nervous system neoplasms. J Clin Invest 1993;91:153-159 
65. Km KJ, Li B, Winer J, Armanin M, Gillet N, Phillips HS, Ferrara N. Inhibition of vascular endorhelial growth factor-induced angiogenesis suppresses tumour growh in vivo. Nature 1993;362-841-844

66. Baurers C, Asahara T, Zheng L.P, Takeshica S, Bunting S. Ferrara N, Symes JF, Isner JM. Sire-specific therapeutic angiogemesis after systemic administration of wascular endorhelial growth factor. f Wasc Surg $1995 ; 21: 31,4-325$

67. Takeshita 5 , Zheng LP, Brogi E, Kearney M, Pu L-Q. Buntinmg S, Ferrara N, Symes JF, Isner JM. Therapeutic angiogenesis. A single bolus of vascular endothelial growth factor augments revascularization in a rabbir ischemic hind limb model. / Clin Invest 1994;93:662-670

68. Bauters C, Asahara T, Zheng LP, Takeshita S, Bunting S, Ferrara N, Symes JF, Isner JM. Physiological assesment of augmented wascularity induced by VEGF in ischemic tabbit hindlimb. Am $/$ Physiol $1994 ; 267: H 1263-H 1271$

69. Takeshita $\mathrm{S}$, Rossow ST, Kearney $\mathrm{M}$, Zheng LP, Bauters $\mathrm{C}$, Bunting $\mathrm{S}$, Ferrara $\mathrm{N}$, Symes JF, Isner JM. Time course of increased cellular proliferation in collateral arteries after administration of vascular endorhelial growth factor in a rabbit model of lower limb vascular insufficiency. Am I Pathol $1995 ; 147: 1649-1660$

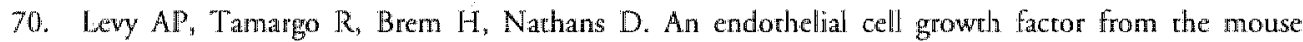
neuroblastoma cell line NB41. Growth Factors 1989;2:9-19

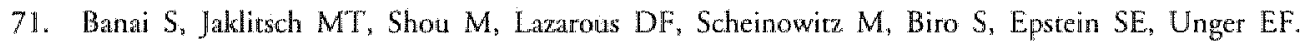
Angiogenic-induced enhancement of collateral blood flow to ischemic myocardium by vascular endothelial growth factor in dogs. Circulation 1994:89:2183-2189

72. Isner JM, Pieczek A, Schainfeld R, Blair R, Halley L, Asahara T, Rosenfield K, Razwi S, Walsh K, Symes $J F$. Clinical exidence of angiogenesis after arterial gene transfer of phVEGF 165 in patient with ischemic limb. Lawcet 1996;348:370-374

73. Isner JM, Walsh K, Symes JF, Piezcek A, Takeshita S, Lowry I, Rosenfield K, Weir L, Brogi E, Jurayj D. Arterial gene therapy for therapeutic angiogenesis in patients with peripheral artery disease. Circulation 1995:91:2687-2692

74. Sellke FW, Quillen JE, Brooks LA, Harrison DG. Endochelial modularion of the coronary vascularure in vessels perfused wia mature collateralls. Circulation 1990;81:1938-1947

75. Bauters C, Asahara T, Zheng LP, Takeshita $S_{0}$ Bunting S, Ferrara N, Symes JF, Isner JM. Recovery of discurbed endorhelium-dependent How in the collareral-perfused rabbic ischemic hindlimb following administration of vascular endorhelial growth factor. Circulation 1995:91:2802-2809

76. Essed CD, Brand MVD, Becker AE. Transluminal coronary angioplasty and early restenosis. Br Heart $\int 1983,49: 393-402$

77. Asahara T, Bauters C. Pastore CJ, Kearncy M, Rossow S, Buncing S, Ferrara N, Symes JF, Ismer JM. Local delivery of vascular endothelial growth factor accelerates reendothelializion and attentuates intimal lyperplasia in balloon-injured rat carotid artery. Circulation 1995:91:2793-2801

78. Furchgotr RF. Zawadzki JV. The obligatory role of endothelial cells in relaxation of arterial smooth muscle by acctylcholine. Natare 1980:288:373-376

79. Palmer RMJ, Ferrige AG, Moncada S. Nitric oxide release accounts for the biological activity of endothelum-derived relaxing facror. Nature 1987;327:524-526

80. Palmer RMJ, Ashron DS, Moncada S. Vascular endorhelial cells synthesize nitric oxide from L-arginine. Narure 1988:333:664-666

81. Ignarro LI. Buga GM. Wood KS, Byrns RE. Endorhelium-deriwed relaxing facror produced and released from artery and wein is nitric oxide. Prac Natl Aard So U SA 1987:84:9265-9269

82. Stamler $\ S$, Singel DJ, Loscalzo ]. Biochemistry of nitric oxide and its redox-activated forms. Srience $1992 ; 258: 1898-1902$

83. Archer S. Measurement of nitric oxide in biological models. FASEB / 1993;7:349-360

84. Wenmahn A, Benthin G, Petersson A-S. Dependence of metabolism of nitric oxide (NO) in healthy human whole blood on the oxygenation of its red cell haemoglobin. Br/ Pharnatal 1992;106:507-508

85. Lancaster JR. Simulation of the diffusion and reacrion of endogenously produced nitric oxide. Proc Nanl Acad Sci U SA 1994:91:8137-8141 
86. Sessa WC. The nitric oxide synthase family of proteins. / Vace Re 1994;31:131-143

87. Marsden PA, Schappert KT, Chen HS, Flowers M, Sundell CL, Wilox JN, Lamas S, Michel T. Molecular cloning and characterization of human endothelial nitric oxide synthase. PEBS Let $1992 ; 307: 287-293$

88. Nishida K, Harrison DG, Navas JP, Fisher AA, Dockery SP, Uematsu M, Nerem RM, Alexander RW. Murphy TI. Molecular cloning and characterization of the constiturive bovine aortic endothelial cell nicric oxide synthase. J Clin fovest 1992;90:2092-2096

89. Furchgot RF, Vanhoutte PM. Endothelium-derived relaxing and contracting factors. FASEB $J$ 1987;3:2007-2018

90. Bogle RG, Moncada S, Pearson CD, Mann GE. Identification of inhibitors of nitric oxide synthase that do not interact with the endathelial cell L-arginine transporter. Br / Pharnacol 1992;105:768-770

91. Buckley BJ, Mirza Z, Whorton AR. Regulation of $\mathrm{Ca}^{2+}$-dependent nitric oxide synthase in bovine aortic endothelial cells. Am J Physiol 1995;269:C757-C765

92. Sessa WC, Barber $\mathrm{CM}$, Lynch KR. Mutation of $N$-myristoylation site converts endorheliall cell nitric oxide synthase from a membrance to a cytosolic protein. Circ Res 1993:72:921-924

93. Kanai AI, Strauss HC, Truskey GA. Crews AL, Grunfeld S, Malinski T. Shear stress induces ATP-independent transient nitric oxide release from vascular endorhelial cells, measured directly wirh a porphyrinic microsensor. Circ Res 1995:77:284-293

94. Lamontagne D, Pohl U, Busse $\mathbb{R}$. Mechanical deformarion of the vessel wall and shear stress determine the basal release of endothelium-derived relaxing factor in the intact rabbit coronary vascular bed. Cire Res $1992,70: 123-130$

95. Iida $S$, Ohshima $H$, Oguchi $S, H a c a T$, Suzuki $H$, Kawasalki $H$, Esumi $H$. Identification of inducible callmodulin-dependent nirric oxide synthase in the liver of rats. J Biol Chem 1992;267:25385-25388

96. Cho HI. Xie QW, Calaycay J, Mumford RA, Swiderek KM, Lee TD, Nathan C. Calmodulin is a subunit of nitric oxide synchase from macrophages. / Exp Med 1992;176:599-604

97. Geller DA, Nussler AK, Di Silvio M, Lowenstein CJ, Shapiro RA, Wang SC, Simmons RL "Billiar "TR. Cytokines, endotoxin, and glucocorticoids regulate the expression of inducible nitric oxide synthase in hepatocyces. Proc Natl Acad Soi US A 1993;90:522-526

98. Estrada $\mathrm{C}$, Gomez $\mathrm{C}$, Martin $\mathrm{C}$, Moncada S, Gonzalez C. Nitric oxide mediates tumor necrosis factor- $\alpha$ cytotoxicity in endothelial cells. Brocbem Bioplyys Res Commun 1992;186:475-482

99. Wright CE, Rees DD. Moncada S. Protecrive and pathological roles of nitric oxide in endoroxin shock. Cardionats Res 1992;26:48-57

100. Radomski MW, Palmer RMj, Mancada S. Glucocorticoids inhibit the expression of an inducible, but not the constiturive, nitric oxide synthase in vascular endothelial cells. Proc Nat Acad Sri USA $1990 ; 87: 10043-10047$

101. Lorsbach RB, Murphy WJ, Lowenstein CJ, Snyder SH, Russell SW. Expression of the nivric oxide. synthase gene in mouse macroplages activated for tumor cell killing: Mollecular basis for the synergy between interferon- $\tau$ and lipopolysaccharide. / Brol Chem 1993;268:1908-1913

102. Keeton WT, ed. The Elements. In: Biological Sitince. W.W. Norton \& Company, 3rd edicion; 1976:27-29

103. Ignarro LJ, Murad F, eds. Nirric oxide: biochemistry, molecular biology, and therapeutic implications. In: Adtanues in Pharmacalogy. New York, NY: Academic Press; 1995:34:1-516

104. Mulligan MS, Moncada S, Ward PA. Protective effects of inhibitors of nitric oxide synrhase in immune complex-induced vasculitis. Br J Pbarmacol 1992;107:1159-1162

105. Radornski MW, Palmer RMJ, Moncada S. An L-arginine/nitric oxide pathway present in human platelets regulates aggregation. Proc Nat Acad Sci U S A 1990;87.5193-5197

106. Radomski MW, Palmer RMJ, Moncada S. Endogenous nitric oxide inhibits human platellet adhesion to vascular endorhelium. Lancet 1 987;2: 1.057-1058

107. Kubes P, Suzuki M, Granger DN. Nitric oxide, an endogenous modulator of leukocyte ad hesion. Proc Nan Acad Sei U S A 1991:88:4651-4655 
108. Khan BV, Harrison DG, Olbrych MT, Alexander RW, Medford RM. Nitric oxide regulares vascular cell adhesion molcculle 1 gene expression and redox-sensirive rranscriprional evenrs in human vascular endothelial cells. Proc Nati Acad So U S A 1996;93:9114-9\|19

109. Raffer $\int$, Aronson WJ, Bush PA, Dorey FJ, Ignarro LJ. Nirric oxide as a mediator of relaxacion of the corpus cavernosum in response to nonadrenergic, noncholinergic neurotransmission. $N$ EnglJ Med $1992 ; 326: 90-94$

110. Johmson RA, Freman RH. Sustained hypertension in the rat induced by chronic blockade of nitric oxide production. Am / H ypertension 199255:919-922

111. Izumi Y, Cliford DM, Zorumski CF. Inhibition of long-rem potentiation by NMDA-ratiated nitric oxide release. Science 1992;257:1273-1275

112. Wilcox CS, Welch WJ, Murad E, Gross SS, Taylor G, Levi R, Schmidt HH. Nitric oxide synthase in macula densa regulates glomerullar capillary pressure. Proc Nat Acad So US A 1992;89:11993-1 1997

113. Nathan C. Nitric oxide as a secretory product of mammalial cells. FASEB / 1992;6:3051-3064

114. Vanderwinden J-M, Mailleux I. Schiffmann SN, Vanderhaeghen J-J. De Laar M-H. Nirric oxide synchase activity in infantile hypertrophic pyloric stenosis. $N$ Engl J Med 1992;327:511-515

115. Baevo JA, Reifsnyder DH. Primary sequence of cyclic nucleotide phosphodiesterase isoenrymes and the design of selective inlaibitors. Trends Pharmacol Sci 1990;11:150-155

116. Archer SL, Huang JM, Hampl V, Nelson DP, Schulaz PJ, Weir EK. Nitric oxide and CGMP cause vasorelaxation by activation of a charybdotoxin-sensitive $\mathrm{K}$ channel by CGMP-dependent protein kinase. Proc Natl Acad S i USA 1994:91:7583-7587

1.17. Pateno R, Faraci FM, Heistad DD. Role of $\mathrm{Ca}^{2 *}$-dependent $\mathrm{K}^{*}$ channels in cerebral vasodilatation induced by increases in cyclic GMP and cyclic AMP in the rat. Stroke 1996;27:1603-1608

118. Barnetr RL, Ruffini L, Ramsammy L, Pasmancier R, Friedlacnder MM, Nord EP. cGMP antagonizes angiotensin-mediated phosphatidylcholine hydrolysis and kinase activation in mesangial cells. Am If Physial 1995;268:C376-C381

119. Yu S-M, Hung L-M, Lin C-C. oGMP welevating agents suppress proliferation of vascular smooth muscle cells by inhibiting the acrivation of epidermal growth factor signaling pathway. Circulation 1997;95:1269-1277

120. Nishida E, Gotoh Y. The MAP' kinase cascade is essential for diverse signal transduction pathways. Trends Pharmacol Sci 1993;18:128-131

121. Seth A, Gonzalez EA, Gupta $S$, Raden DL, Davis RJ. Signal transduction within the nucleus by mirogenwacrivared protein kinase. J Biol Chem 1992;267:24796-24804

122. Bourcier T, Dockter $M_{n}$ Hassid A. Synergistic intenaction of interleukim-1 13 and growth factors in primary cultures of rat aortic smooth muscle cells. / Cell Pbysial 1995:164:644-657

123. Peunova $\mathrm{N}$, Eanikolopov $\mathrm{G}$. Nicric oxide triggers a switch to growth arrest during differentiation of neuronal cells. Natwre 1995; $375,68-73$

124. Pollman M], Ymada T", Horiuchi M, Gibbons GH. Vasoacrive substances regulate vascular smooth muscle cell apoptosis. Countervailing influences of nicric oxide and angiotensin II. Circ Res $1996: 79: 748-756$

125. Rubbo H. Radi R. Trujillo M, Telleri R, Kalyanaramau S, Barnes S, Kirk M, Freeman BA. Nirric oxide regulation of superoxide and peroxynitrite-dependent lipid peroxidation. Formation of novel nitrogencontaining oxidized lipids. / Btol Chem 1994:269:26066-26075

126. Nishio E. Fukushima K, Shiozaki M. Watanabe Y. Nitric oxide donor SNAP induces apoprosis in smooth muscle cells through a CGMP-independent mechanism. Biochem Biophys Res Common 1996:221:163 168

127. Beckman JS, Koppenol WH. Nirric oxide, superoxide, and peroxynitrite: the good, the bad, and the ugly. Am J Phyiol 1996;271:C1424-C1437

128. Sampson JB, Rosen H, Beckman JS. Peroxynitrite dependent tyrosine nitration catalyzed by superoxide. dismutase, myeloperoxidase and horseradish peroxidase. Methods Enzymol 1996;269:210-218 
129. Ungureanu-Longrois D, Balligand J-L. Kelly RA. Smith TW. Myocardial contractile dysfunction in the systemic inflammatory response syndrome role of a cytokine-inducible nitric oxide synthase in cardiac myocytes. / Mol Cell Cardiol 1995;27:155-167

130. Imlay JA. Fridovich 1. Assay of metabolic superoxide producrion in Escherichia coli. f Biol Chem $1991 ; 266: 6957-6965$

131. Huie RE, Padmaja S. The reaction rate of nitric oxide with superoxide. Free Radical Res Common $1993 ; 18: 195-199$

132. Ohara Y, Peterson TE, Harrison DG. Hypercholesrerolemia increases endorhelial superoxide anion production. J Clin Invest 1993;91:2546-2551

133. Munro IM, Cotran RS. The parhogenesis of atherosclerosis atherogencsis and inflammation. Lab Jwest $1988 ; 58: 249-261$

134. Graham A, Hogg N, Kalyanaraman B, O'Leary V, Darley-Usmar V, Moncada S. Peroxynitrite modification of low-densiry lipoprotein leads to recognition by the macrophage scavenger receptor. FEBS Lett 1993;330:181-185

135. Gerrity R. The role of the monocytes in atherogenesis, I: transition of blood-bone monocytes into foam cells in farty lesions. Am J Pathol 1983:103:18:190

136. Marui N, Offermann MK, Swerlik R, Kunsch C, Rosen CA, Ahmad M, Alexander RW, Medford RM. Vascular cell adhesion molecule-1 (VCAM-1) gene transcription and expression are regulared through an antioxidant-sensitive mechanism in human vascular endothelial cells. J Cln Invest 1993;92:18661874

137. Navab M, Imes SS, Hama SY, Hough GP, Ross LA, Bork RW, Valente A], Berliner JA, Drinkwater DC, Laks H, Fogelman AM. Monocyte transmigration induced by modification of low density lipoprotein in cocultures of human aortic wall cells is due to induction of monocyte chemotacric protein 1 synthesis and is abolished by high density lipoprotein. / Clin Invest 1991;88:2039-2046

138. Ross R. The pathogenesis of arherosclerosis: a perspective for the 1990s. Nature 1993:362:801.

139. Kiechle FL, Malinski T. Nitric oxide. Biochemistry, pathophysiology, and detection. Am J Clin Pathol. $1.993 ; 100: 567-575$

140. Peters KG, de Vries C, Williams LT. Vascular endothelial growth factor receptor expression during embryogenesis and tissue repair suggests a role in endothelial differentiation and blood vessel growth. Proc Nat Acad Sci US A 1993;90:8915-8919

141. Garg UC, Hassid A. Nitric oxide-generating vasodilators and Bubromo-cyclic guanosine monophosphate inhibit mitogenesis and proliferation of cultured rat vascular smooth muscle cells. $J$ Clin Intest 1989:83:1774-1777

142. Marks DS, Vita JA, Folrs JD, Keany JF, Welch GN, Loscalzo J. Inhibition of neouncimal proliferation in rabbits after vascular injury by a single treatment with a proten adduct of nitric oxide / Clin linest $1995 ; 96: 2630-2638$

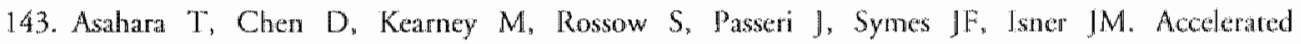
reendothelialization and reduced neoincimal thickening following catheter ransfer of phVEGF ${ }_{\text {ris. }}$. Am Coll Cardiol 1996,27: IA(Abstract)

144. Tschudi MR, Barton M, Bersinger NA, Moreau P, Cosentino F, Noll G, Maliniski T, Lüscher TF. Effect of age on kinerics of nitric oxide release in rat aorta and pulmonary artery. I Clin Invest $1996,98: 899-905$

145. Quyyumi AA, Dakak N, Andrews NP, Husain S, Arora S, Gilligan DM, Panza JA, Cannon III RO. Nitric oxide activiry in the human coronary circulation. Impact of risk factors for coronary arherosclerosis. / Clin Invest 1995:95:1747-1755 



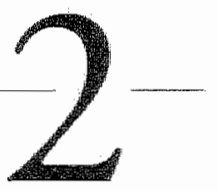

\section{Vascular Endothelial Growth Factor/Vascular Permeability Factor Augments Nitric Oxide Release From Quiescent Rabbit and Human Vascular Endothelium}

Rien van der Zee, MD; Toyoaki Murohara, MD; Zhengyu Luo, MD; Frank Zollmann, BS; Jonathan Passeri, BA; Carsten Lekutat, BS; Jeffrey M. Isner, MD

From the Departments of Biomedical Research and medicine (Cardiology), St. Elizabeth's Medical Center, Tufts University, School of Medicine, Broston, MA 02135

Published in Circulation 1997;95:1030-1037 


\section{Abstract}

\section{Buckgrownd}

Vacular endothelial growth factor (VEGF)/vascular permeability factor (VPF) is an evalowetial cell (EC) mitogen. This feature is considered central to the docwmented role of VEGFIVF in promoting angiogenesis. Mare recent evidence suggests that VEGFVPF may also serve a "maintenance" function modulating warious aspects of EC biology. In the present study we sought to detemine the extent to which VEGF/VPF may stimulate the release of nirnic oxide (NO) frow normal ECs.

\section{Methods and results}

Vacular segments from the thoracic arta, pulmonary artery, and inferior wena cava of New Zealand white rabbits were placed in an organ chamber and exposed to VEGF/VPF; aliqouts of organ chanber solution were then reacted with Griess solution to determine the production of NO. We observed a dose-dependent rise in NO concentration ([NOJ) upon exposure to VEGF/VPF In comparison to stimulation with actylcholine, the onset of increased INOI following administation of VEGF/VPF was slower, reaching a maximum value afier 8 min. Preincubation of the aortic segments with L-arginine rased by 2-fold both baseline [NO] and [NO] stimulated by addition of $2.5 \mu \mathrm{g} / \mathrm{mal}$ VEGF/RPF. Removal of $\mathrm{CaCl}_{2}$ from the Krebs solution, disruption of the endothelisum, and administration of I-NMMA abrogated the stimwlatory effect of $10 \mu \mathrm{g} / \mathrm{ml}$ VEGF/VPF. Similar findings were dockmented using an NO-specific polaragraphic electrode to measwre NO retease from cultwed hwman ambilical pein ECs.

\section{Conchunon}

VEGFNPF stimulates production of NO from rabbit and buman ECS. This finding: 1) consitutes inferential evidence for the presence of functional VEGTVIP receprors on quiescent endothelitum of the adult rabbit, as well as buman ECs; and 2) supports the notion that putative mativtenawce functions of VEGFVPF may include regulation of baseline synthesis and or release of ECNO. 
The factors which govern the production of nirric oxide (NO) by endothelial cells (ECs) of the arterial wall have been shown to include physical factors such as shear stress ${ }^{1 / 2}$ and cyclic stretching 3,4 , and neurohumoral factors, most notably acetylcholine ( $\mathrm{ACh}$ ) and bradykinin. ${ }^{5}$ The extent to which cytokines elaborated by the arterial wall may further modulate EC production of NO has been less well studied.

Vascular endothelial growth factor (VEGF)/vascular permeability factor (VPF) constitutes a possible candidate for this role. VEGF/VPF is a $45-\mathrm{kD}$ heparin-binding dimeric glycoprotein that is mitogenic for ECs. ${ }^{6,78}$ The possibility that the effects of $\mathrm{VEGF/VPF}$ on EC biology extend beyond mitogenesis and/or migration to involve a "maintenance role" has been previously suggested by Peters et al" and others. ${ }^{10,11,12}$ Consistent with this notion, VEGF/VPF has been previously shown by Brock et al ${ }^{13}$ to increase cytosolic $\mathrm{Ca}^{2+}$ in human endothelial cells, and by $\mathrm{Ku}$ et al ${ }^{14}$ to cause dose-dependent relaxation in isolated canine coronary arteries that could be abolished by prior endothelium disruption and/or $\mathrm{N}^{G}$-monomethyl-L-arginine (L-NMMA) pretreatment. Recent studies in our own laboratory have demonstrated that VEGF/VPF promotes recovery of disturbed endothelium-dependent flow in the rabbit ischemic hindlimb, ${ }^{15}$ causes NO-dependent hypotension in two different animal species, ${ }^{16}$ and inhibits intimal thickening in two different animal models of arterial injury. ${ }^{17.18}$

Accordingly, in the present study we sought to determine more directly the extent to which VEGF/VPF may stimulate the release of NO from the normal arterial wall. We first used a spectrophotometric assay based on the reaction of nitrite with Griess reagent to demonstrate a dose-dependent rise in NO concentration in vascular segments freshly harvested from the thoracic aorta, pulmonary artery, and inferior vena cava of New Zealand white rabbits; this reponse was abrogated by endothelial denudation, L-NMMA pretreatment, and/or removal of $\mathrm{CaCl}_{2}$ from the organ bath solution. These findings were then reproduced using an $\mathrm{NO}$-specific polarographic electrode to measure $\mathrm{NO}$ released from cultured human umbilical vein ECs. The results of these experiments thus suggest a potential role for VEGF/VPF in the regulation of $N O$ release from ECs in the vasculature, and parentherically confirm the presence of VEGF/VPF receptors in quiescent adult endothelium.

\section{Material and methods}

\section{Vessel preparations}

Experiments were performed on vessels isolated from mate New Zealand white rabbits of $3000-3500 \mathrm{~g}$. Only male rabbits were used to avoid inconsistent outcomes attributable to gender alone. ${ }^{19}$ The experimental protocol described was conducted according to protocols approved by the St. Elizabeth's Institurional Animal Care and Use Commitree. 
Following premedication with xylazine, $2 \mathrm{mg} / \mathrm{kg}$, rabbits were anesthesized with a mixture of intramuscular keramine (Fort Dodge Laboratories, LA), $50 \mathrm{mg} / \mathrm{kg}$, and acepromazine, $0.8 \mathrm{mg} / \mathrm{kg}$. A small incision was made to expose the carotid artery, following which the upper-most level of the exposed artery was ligated. A 20-guage catheter introduced into the carotid artery was used to infuse $500 \mathrm{ml}$ of $0.9 \%$ saline, mixed with $3 \mathrm{cc}$ heparin (Elkins-Sinn, NJ) and $0.6 \mathrm{ml} \mathrm{ketamin} \mathrm{at} 100 \mathrm{mmHg}$. A second 20-guage catheter introduced in one femoral artery was connected to a small plastic tube for exsanguination. The rabbits died after the larger part of blood was replaced by saline. Immediately after cessation of respiration, the chest was opened and the thoracic aorta (Ao) was excised from the aortic valve to the diaphragmatic hiatus. The inferior vena cava (IVC) was harvested from right atrium to the diaphragm. The pulmonary artery (PA) was excised from the pullmonary valve to its secondary branching. Care was taken during this procedure not to damage or stretch the vessels. After the vessels were taken out, they were barhed in Krebs solution containing (in mmol/l) $\mathrm{NaCl} 118, \mathrm{KCl} 4.6, \mathrm{NaHCO}_{3}$ $27.2, \mathrm{MgSO}_{4} 1.2, \mathrm{CaCl}_{2} 2.5, \mathrm{KH}_{2} \mathrm{PO}_{4} 1.2$, and glucose $11.1(\mathrm{pH} 7.4$ ), aerated with a $95 \% \mathrm{O}_{2}-5 \% \mathrm{CO}_{2}$ gas mixture, and maintained at a constant temperature of $37{ }^{\circ} \mathrm{C}$. Connective and other adhesive tissue was completely removed because it contained blood. Any remaining blood was removed by placing the excised vascular segments in Krebs solution for $5 \mathrm{~min}$. The segments were then cut at $5-\mathrm{mm}$ intervals to allow each segment optimal time for exposure to oxygen and administered drugs. One segment of Ao from each rabbit was used for analysis of vasomotor reactivity following administration of VEGF/VPF (vide infra). For certain experiments, the endothelium was removed by gently rubbing the interior of the vessel with a cotton swab prewetted with Krebs solution.

\section{Measurements of NO from vessel segments}

Vessel segments were allowed to float for $10 \mathrm{~min}$ in the organ chamber, before its content was replaced with $10 \mathrm{ml}$ of fresh Krebs solution, to remove any remaining hemoglobin. Fifteen minutes later $(\mathrm{t}=0)$, reagents to be tested were administered. In our experience 15 min was the minimal time necessary for the vascular segments to equilibrate with the Krebs solution in the organ chamber. Concentrated solutions were employed to avoid any significant increase in volume administered immediately after replacement of the Krebs solution (i.e. $\mathrm{t}=-15$ ).

To measure nitric oxide concentration ([NO]) at different points in time, $0.7 \mathrm{ml}$ aliqours of organ chamber solution were removed and added to a $1 \mathrm{ml}$ cuvette with an optical parth of $1 \mathrm{~cm}$, containing $0.07 \mathrm{ml}$ of Griess solution ( $1 \%$ sulfanilic acid, $0.1 \%$ naphrhalene-cthylene diamine in $\left.5 \% \mathrm{H}_{3} \mathrm{PO}_{4}\right)$. Naphthalene-ethylene diamine reacts wirh $\mathrm{NO}$ as well as with nitrite $\left(\mathrm{NO}_{2}{ }^{-}\right)$to yield a product that renders the solution pink; the resulting product yields a spectrophotometric peak at $548 \mathrm{~nm} .{ }^{20}$ We found that a 1:10 ratio of Griess solution to sample volume yielded results which were equal to the 
more commonly used ratio of $1: 1$; reducing the volume of Griess solution avoided diluting the $[\mathrm{NO}]$ of the sample volume in the cuvette, and increasing the sensitivity of the measurement. Immediately after removing the last sample from the organ chamber, the absorbance at $548 \mathrm{~nm}$ was measured using a diode array photospectrometer $(8452 \mathrm{~A}$, Hewlett Packard, Andover, MA). Absorbance was proportional to [NO], according to a standard curve that, in our hands, was linear from 0.01 to $0.25 \mu \mathrm{mol} / 1 \mathrm{NO}_{2}{ }^{\circ}$. (figure 1). The Griess reaction has been typically reported to yield a sensitivity between 1 and 5 $\mu \mathrm{mol} / \mathrm{l}$. By diluting a $1 \mu \mathrm{mol} / 1 \mathrm{NO}_{2}^{-}$sample by a factor 2 until concentrations of $0.015625 \mu \mathrm{mol} / 1$ were obtained, we registered absorbances in the different solutions as displayed in the Table. The resulting standard curve, based on four independent procedures, was virtually linear, including the range from 1 to $0.01 \mu \mathrm{mol} / /$ (Figure 1).

Table 1. The repetirive measurements for construction of the standard curve.

\begin{tabular}{|c|c|c|c|c|c|c|c|}
\hline$\left[\mathrm{NO}_{2}{ }^{-}\right] \quad(\mu \mathrm{mol} / \mathrm{l})$ & blank & 0.015625 & 0.03125 & 0.0625 & 0.125 & 0.25 & 0.5 \\
\hline \multicolumn{8}{|l|}{ Absorbance } \\
\hline $\mathbb{1}$ & -0.00003 & 0.00299 & 0.00624 & 0.01685 & 0.03285 & 0.07053 & 0.14297 \\
\hline $\mathbb{I I}$ & 0.00003 & 0.00290 & 0.00659 & 0.01707 & 0.03285 & 0.07066 & 0.14299 \\
\hline $\mathbb{I I I}$ & 0.00003 & 0.00313 & 0.00661 & 0.01697 & 0.03264 & 0.07057 & 0.14323 \\
\hline$\llbracket \mathrm{V}$ & 0.00005 & 0.00371 & 0.00681 & 0.01706 & 0.03305 & 0.07068 & 0.14316 \\
\hline
\end{tabular}

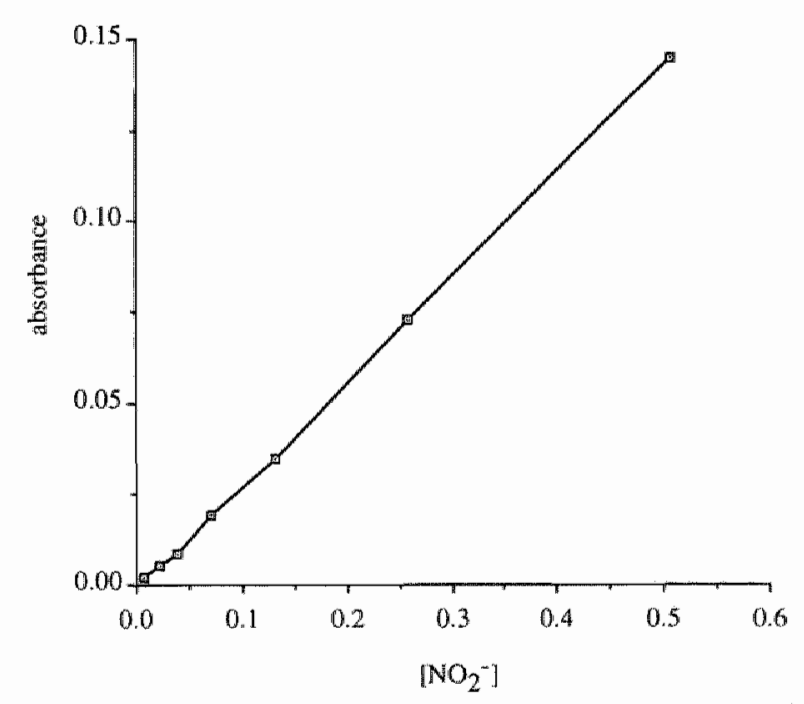

Figure 1. Standard curve constructed with the Griess assay is wirtually linear for nitrite $\left[\mathrm{NO}_{2}\right.$ ] concentrations over range of 0.01 to $0.5 \mu$ molll. 
The same cuvette and volumes were used for experiments involving vascular segments. For a blank, $0.7 \mathrm{ml}$ of Krebs solution, in which no vessel segment had been placed, was added to $0.07 \mathrm{ml}$ of Griess solution. The deviation obtained in the construction of the standard curve was much smaller than the variation in values obtained from processing the solutions derived from the organ bath experiments. Repetitive measurements per sample to ensure that the variability among measurement per sample did nor exceed $10 \%$ and the reproducibility of the documented results suggest that the sensitivity of the Griess reaction for these type of experiments is sufficiently accurate at least to concentrations as small as $0.03 \mu \mathrm{mol} / 1$. It should be noted that the values for NO reported here represent. measured $\mathrm{NO}$ divided by the intimal surface area of the vessel segment (typically 250-700 $\mathrm{mm}^{2}$, vide infra); the product of $\mathrm{NO}$ reported here multiplied by $250-700\left(\mathrm{~mm}^{2}\right)$ yields values which consistently fall within the calibration range of the linear relationship shown in Figure 1.

\section{Calculations}

Four measurements per sample were taken; these were used to compute the average absorbance for each time point. [NO] was determined in the manner described above. The increase in [NO] caused by sampling-induced decrease in volume of the organ chamber solution in the presence of an $\mathrm{NO}$-producing source was corrected for according to the formula:

$\mathrm{C}_{\mathrm{t}}=\mathrm{C}_{\mathrm{x}-2}+\left(\mathrm{C}_{\mathrm{t}}-\mathrm{C}_{\mathrm{x}-2}\right) \cdot\left(\left[\mathrm{V}-\pi \cdot \mathrm{V}_{\mathrm{s}}\right] / \mathrm{V}\right)$

in which $\mathrm{C}_{\mathrm{r}}$ is $[\mathrm{NO}]$ at time $=\mathrm{t} \min ; \mathrm{x}=15 \mathrm{~min} ; \mathrm{V}$ is the initial volume in the organ chamber (i.e. $10 \mathrm{ml}$ ); $\pi$ is number of sampling times; and $V_{\mathrm{s}}$ is the sample volume (i.e. $0.7 \mathrm{ml}$ ). The [NO] $2 \mathrm{~min}$ prior to drug administration was taken as the baseline value.

After completion of the above procedure, the surface area ( $S A$ ) of the vascular segments were carefully measured. The [NO] per SA in $\mu \mathrm{mol} / 1 \cdot \mathrm{mm}^{2}$ at given points in time was described, asuming that production of NO was equal across the endothelium of the excised vascular segments.

\section{Analysis of vasomotor reactivity}

Aortic rings, $5 \mathrm{~mm}$ in length, were mounted using two L-shaped 30-guage stainless steel hooks, one of which was immobile and the orher of which was connected by a silk suture to a force displacement transducer (model 7D polygraph, Grass Instruments Company, Quincy, MA) for recording isometric tension development. The assay was performed with rings placed in Krebs buffer as described above. Vessels were passively stretched to $2.0 \mathrm{~g}$ isometric force. After $45 \mathrm{~min}$ of equilibration, the aortic rings were exposed to 70 $\mathrm{mmol} / \mathrm{KCl}$ solution to assess the effecr of maximal depolarization. When the contractile response reached a plateau phase, the solution in the organ chamber was replaced by fresh Krebs buffer and again was allowed to equilibrate for $45 \mathrm{~min}$ in the presence of $5 \mu \mathrm{mol} / \mathrm{C}$ 
indomethacin for complete inhibition of the cyclooxygenase and consequent production of vasoactive prostanoids. Norepinephrin (NE) was used to achieve submaximal tone, defined as 30-50\% of maximal tone induced by $\mathrm{KCl}$, following which VEGF/VPF was added in a cumulative fashion to the organ bath solution. The effect of VEGF/VPF was measured as the percentage change in NE-induced vascular tone.

\section{Measurement of NO from HUVECs}

Human umbilical vein endothelial cells (HUVECs) were isolated from human umbilical cords by collagenase dissociation and grown onto $1 \%$ gelatin-coated plates in medium 199 (Life Technologies, Gaithersburg, MD) with 20\% heat-inactivated fetal bovine serum (Life Technologies), $100 \mathrm{mg} / \mathrm{ml}$ endothelial cell growth supplement and 50 units/ml heparin (HUVEC medium). ${ }^{21}$ Cells were passaged at confluence following dissociation with $0.05 \%$ trypsin (Life Technologies). Cultured HUVECs were used between passages 5 and 6 .

NO release from a cultured HUVEC monolayer was measured with an $\mathrm{NO}$-specific polarographic electrode connected to an NO meter (Iso-NO, World Precision Instruments, Sarasota, FL). ${ }^{22}$ Calibration of the NO electrode was performed daily before beginning the experimental protocol according to the following equation:

$2 \mathrm{KNO}_{2}+2 \mathrm{KI}+2 \mathrm{H}_{2} \mathrm{SO}_{4} \rightarrow 2 \mathrm{NO}+\mathrm{I}_{2}+2 \mathrm{H}_{2} \mathrm{O}+2 \mathrm{~K}_{2} \mathrm{SO}_{4}$

The standard calibration curve was obtained by adding graded concentrations of $\mathrm{KNO}_{2}(0,5,10,25,50,100,250$, and $500 \mathrm{nmol} / \mathrm{l})$ into the calibration solution containing $\mathrm{KI}$ and $\mathrm{H}_{2} \mathrm{SO}_{4}$. The specificity of the Iso- $\mathrm{NO}$ electrode for $\mathrm{NO}$ was previously determined by measurement of NO from authentic NO gas. ${ }^{23}$ The culture medium was removed and the HUVECs were washed twice with Dulbecco's phosphate buffered saline. The cells were then bathed in $5 \mathrm{ml}$ of filtered Krebs solution in 6-well plates. Cell plates were kepr on a slide warmer to maintain a temperature between 35 and $37^{\circ} \mathrm{C}$. For $\mathrm{NO}$ measurements, the sensor probe was inserted vertically into the wells; the tip of the electrode remained $2 \mathrm{~mm}$ under the surface of the solution. the wells containing the confluent HUVECs were randomly divided into five experimental groups: (a) VEGF/VPF (1 $\mathrm{ng} / \mathrm{ml})$, (b) VEGF/VPF (10 $\mathrm{ng} / \mathrm{ml})$, (c) VEGF/VPF $(100 \mathrm{ng} / \mathrm{ml})$, (d) the NO synthase inhibitor L-NAME $(100 \mu \mathrm{mol} / \mathrm{l})+\mathrm{VEGF} / \mathrm{VPF}(100 \mathrm{ng} / \mathrm{ml})$, and $(\mathrm{c})$ sodium nitroprusside $(S N P, 100 \mu \mathrm{mol} / \mathrm{l})$. NO release was expressed as picomoles per 1 $\times 10^{6}$ endothelial cells. Measurements of NO released from HUVECs represent mean values of five to eight measurements in each group (number of cell culture wells).

\section{Reagents}

All reagents, except for VEGF/VPF, were purchased from Sigma Chemical (St. Louis, $\mathrm{MO}$. 
Heterodimeric recombinant VEGF/VPF, purified from Escherichia Coli, was the generous gift of Napoleone Ferrara, Bruce Keyt, and Stuart Bunting, Genentech Inc., South San Fransisco, CA. All VEGF/VPF concentrations are reported in $\mathrm{g} / \mathrm{l}$. Previous analyses ${ }^{24}$ disclosed that $E$. Coli-derived VEGF/VPF appeared as a single protein band on SDS-gels with a molecular weight of $39.8 \mathrm{kDa}$; the concentrations of VEGF/VPF used in the current experiments $(2.5$ and $10 \mu \mathrm{g} / \mathrm{ml})$ thus correspond to 62.8 and 251.0 nmol/l, respectively.

Krebs solution and Griess reagent were prepared daily. Stock solutions of VEGF/VPF and $\mathrm{ACh}$, dissolved in distilled water, were refrigerated until they were used. Pellets of L-arginine and L-NMMA were added to the organ chamber at established concentrations of $0.2 \mathrm{mmol} / \mathrm{l}$.

\section{Statistical analysis}

Values are given as means \pm standard error $(m \pm S E M)$. If $n=2$, bars indicate the range of obtained values. The data were evaluated using a 2 -factorial (significance over time, significance of drug effects) analysis of variance (ANOVA) for repeated measurements. Statistical significance was inferred when $p<0.05$. In all experiments, $n$ equals the number of rabbits from which the vessels were taken.

\section{Results}

\section{Thoracic aorta}

Stimularion of vascular segments of thoracic aorta ( $\mathrm{Ao}$ ) with $\mathrm{ACh}$ resulted in a nearly immediate and significant increase in [NO] (Figure 2). Stimulation with $10^{-5} \mathrm{~mol} / 1 \mathrm{ACh}$ yielded a somewhat higher [NO] than observed with $10^{-6} \mathrm{~mol} / \mathrm{l} \mathrm{ACh}$, but this difference was not statistically significant. No increase in [NO] was observed when $0.2 \mathrm{mmol} / /$ L-NMMA was administered at time $\mathrm{t}=0 \mathrm{~min}$.

In comparison with $\mathrm{ACh}$, the onset of increased [NO] following administration of VEGF/VPF was slower, reaching a maximum value after $8 \mathrm{~min}$ (Figure 3). Both tested concentrations $(2.5 \mu \mathrm{g} / \mathrm{ml}$ and $10 \mu \mathrm{g} / \mathrm{ml})$ caused a significant rise in a dose-dependent fashion. Preincubation of the aortic segments with L-arginine raised by twofold both baseline [NO] and [NO] stimulated by addition of $2.5 \mu \mathrm{g} / \mathrm{ml}$ VEGF/VPF (Figure 4). Removal of $\mathrm{CaCl}_{2}$ from the Krebs solution abrogated the stimulatory effect of $10 \mu \mathrm{g} / \mathrm{ml}$ VEGF/VPF, resulting in [NO] that did not differ significantly from baseline conditions or from unstimulated aortic rings (Figure 5). Similar results were observed following mechanical removal of the endothelium. Administration of $0.2 \mathrm{mmol} / 1 \mathrm{~L}-\mathrm{NMMM}$ at time $\mathrm{t}=0 \mathrm{~min}$ also prevented any rise in $[\mathrm{NO}$ ] after stimularion with $10 \mu \mathrm{g} / \mathrm{ml}$ VEGF/VPF. Moreover, incubating with L-NMMA produced a tendency to diminished $[\mathrm{NO}$, compared to the values obtained for the unstimulared aortic rings. 


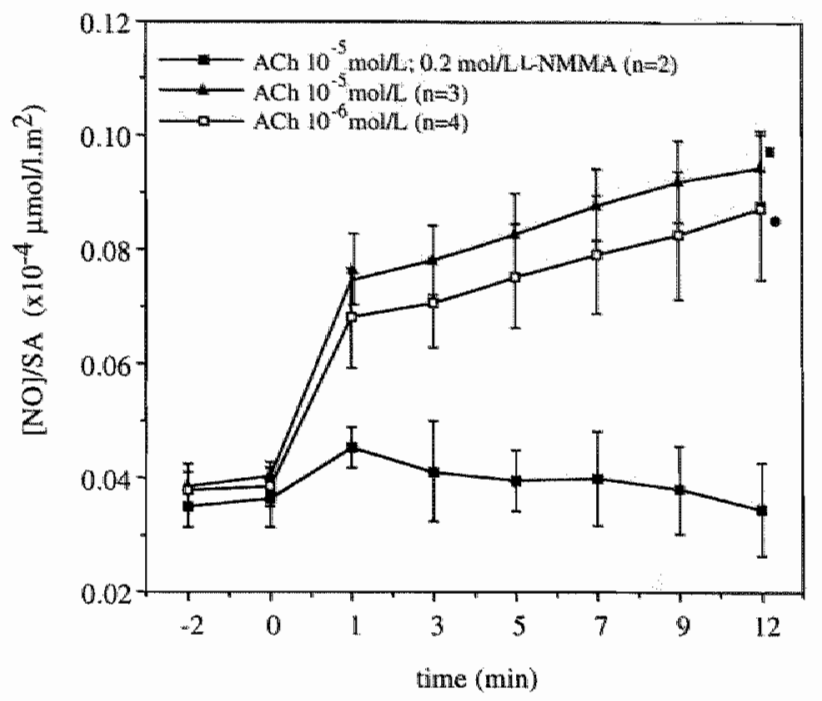

Figure 2. Acecylcholine (ACh), in concentrations of boch $10^{-5} \mathrm{~mol} / 1$ and $10^{-6} \mathrm{~mol} / 1$, augments nitric oxide (NO) production by thoracic aorta. No increase in [NO] was observed when $0.2 \mathrm{mmol} / \mathrm{N} \quad \mathrm{N}^{\mathrm{G}}$-monomethyl-L-arginine (L-NMMA) was administered at $t=0 \mathrm{~min}$. SA: surface area; $\bullet, \mathbb{0}<0.05$ versus $A C h 10^{-5} \mathrm{~mol} / / / \mathrm{L}$ NMMA. The difference berween $\mathrm{ACh} 10^{-6} \mathrm{~mol} / \mathrm{l}$ and $\mathrm{ACh} 10^{-5}$ mol/l was not statistically significant.

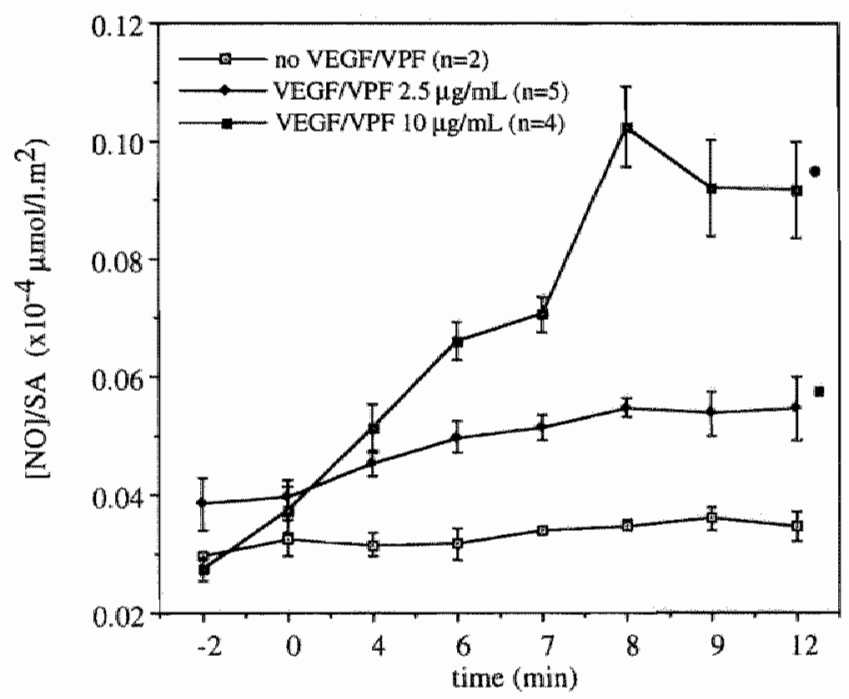

Figure 3. Vascular endorhelial growth factor (VEGF)/vascular permeability factor: (VPF) angments nitric oxide (NO) production by thotacic aorta. I, n: $\mathrm{p}<0.05$ versus no VEGF/VPF. SA: surface area. 


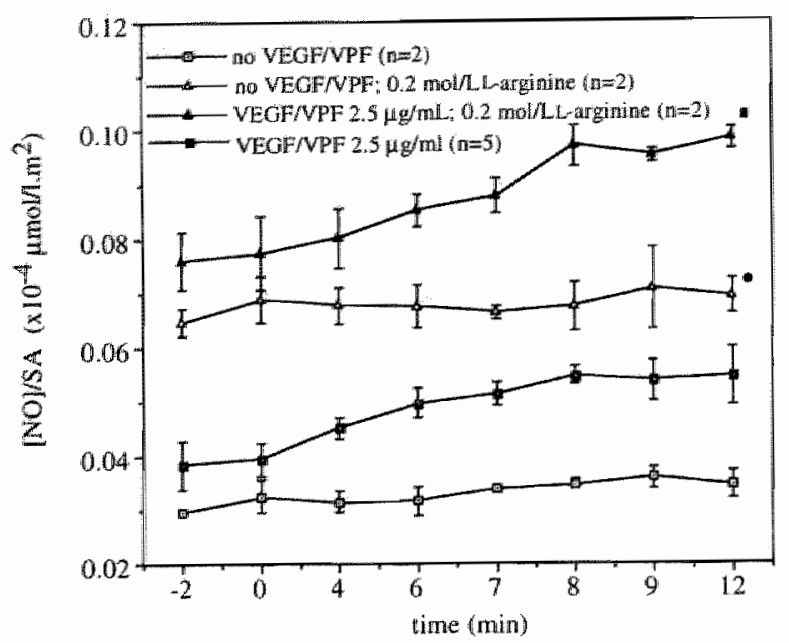

Figure 4. Larginine augments production of nitric oxide (NO) by thoracic aorta. -: p 0.05 versus no vascular endorhelial growela factor (VEGF)/vascular permeabilicy facror (VPF) a: $p<0.05$ wersus VEGF/VPF $2.5 \mu \mathrm{g} / \mathrm{ml}$.

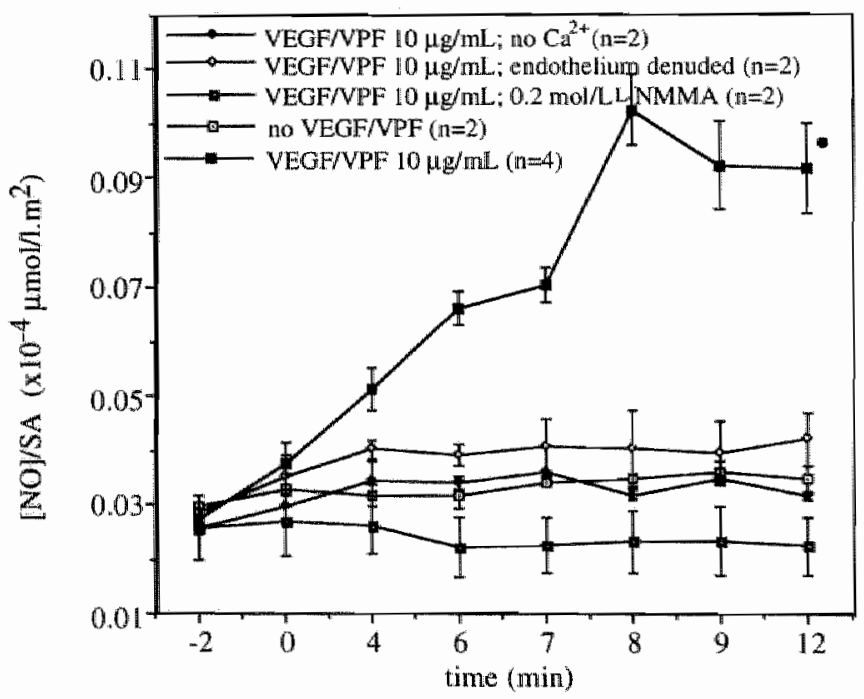

Figure 5. Inhibition of nitric oxide (NO) protuction during application of vascular endorhelial growdh actor (VEGF)/vascular permeability factor (VPF) to thoracic aorta. $\mathrm{No} \mathrm{Ca} 2+\mathrm{CaCl} 2$ remowed from Krebs solution in the organ chamber. 1: $p<0.05$ versus all other curves. The differences berween curves demonserating the inhibition of NO production were not stacistically significant. L-NMMA: NG-monomethyl-Larginine. SA: surface areat. 


\section{Inferior vena cava}

After stimulation with VEGF/VPF, vascular segments retrieved from the inferior vena cava (IVC) yielded results wich were similar to those obcained for Ao segments (data nor shown). [NO] for unstimulated IVC was nearly identical to that obtained for Ao; stimulation of IVC with $2.5 \mu \mathrm{g} / \mathrm{ml}$ and $10 \mu \mathrm{g} / \mathrm{ml}$ and $10 \mu \mathrm{g} / \mathrm{mL}$ VEGF/VPF, however, yielded a lower [NO] than recorded for the Ao.

In contrast to results obtained in the Ao with VEGF/VPF, ACh applied to the IVC failed to produce a significant increase in [NO] (Figure 6).

\section{Pulmonary artery}

For vascular segments retrieved from the pulmonary artery (PA), $2.5 \mu \mathrm{g} / \mathrm{ml}$ VEGF/VPF did not lead to an increase in [NO] compared to results obtained for the unstimulated segments (data not shown). Stimulation with $10 \mu \mathrm{g} / \mathrm{ml}$ VEGF/VPF, however, did yield a significant rise in [NO], though peak levels in the Ao and the IVC segments were higher. Preincubation with $0.2 \mathrm{mmol} / \mathrm{L}$-arginine increased [NO] similar to findings recorded for Ao and IVC.

Again, as in the case of the IVC, ACh did not result in a rise in [NO] (Figure 7).

\section{Vasomotor reactivity}

Figure $8 \mathrm{~A}$ shows the representative vasomotor response obtained from an endotheliumintact ring of rabbit aorta following administration of VEGF/VPF. Norepinephrin was used to induce the initial vasomotor tone. VEGF/VPF produced slowly developing relaxation, reversible with L-NMMA. This effect was also abolished after mechanical removal of the endothelium and by removal of $\mathrm{CaCl}_{2}$ from the organ bath solution (Figure 8B). The time course observed for VEGF/VPF-induced vasomotor reactivity, similar to that originally described by $\mathrm{Ku}$ et a ${ }^{14}$ in isolated canine coronary arteries, is consistent with the rime course of VEGF/VPF-induced release of NO from isolated rings of rabbit aorta described above.

\section{HUVECS}

The Iso-NO electrode was calibrated by a chemical titration method as described in the Materials and Methods (Figure 9A). Stimulation of HUVECs with VEGF/VPF (1, 10, and $100 \mathrm{ng} / \mathrm{ml}$ ) resulted in a concentration-dependent increase in NO release (Figure 9B). Peak NO relaese was observed between 5 to $8 \mathrm{~min}$ after addition of VEGF. Treatment of HUVECs with the NO synthase inhibitor $\mathrm{N}^{\omega}$-nitro-L-arginine methyl ester (L-NAME) $(100 \mu \mathrm{mol} / \mathrm{l})$ attenuated the VEGF/VPF $100 \mathrm{ng} / \mathrm{ml}$-stimulated release of NO under the same experimental conditions. Sodium nitroprusside $100 \mu \mathrm{mol} / \mathrm{l}$ significantly increased [NO]. 


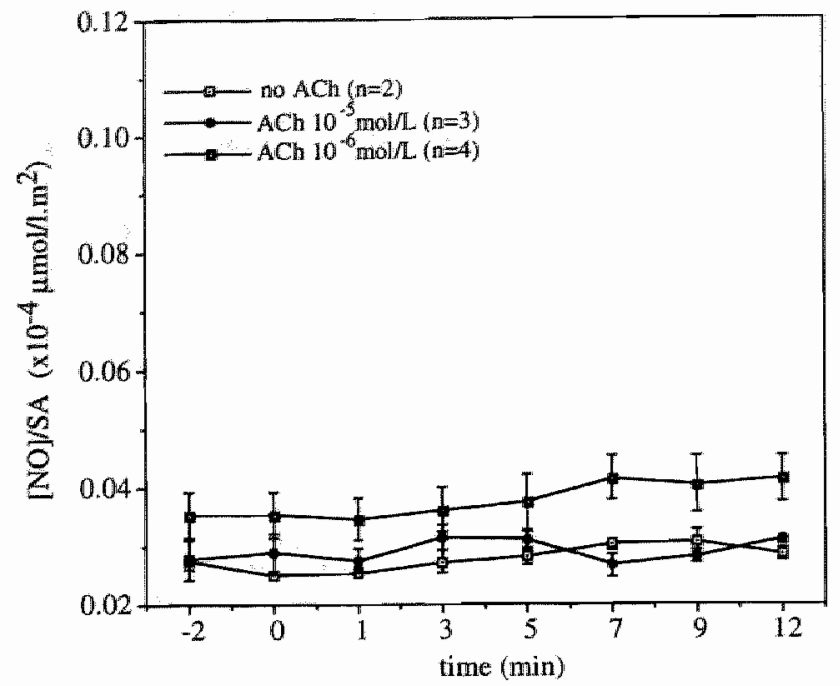

Figure 6. Acetylcholine (ACh), in concentrations of $10^{-5} \mathrm{~mol} / \mathrm{l}$ and $10^{-6} \mathrm{~mol} / \mathrm{l}$, fails ro augment production of nitric oxide (NO) by inferior vena cava. The differences between curves were not staciscically significant. SA: surface area.

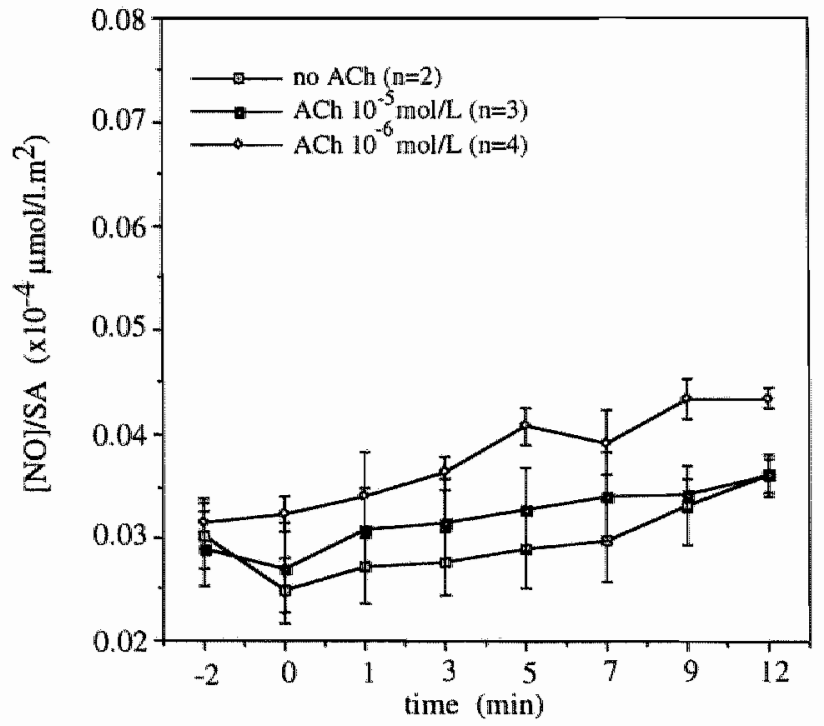

Figure 7. Acetylcholine (ACh), in concentrations of $10^{-5} \mathrm{~mol} / 1$ and $10^{-6} \mathrm{~mol} / \mathrm{l}$, fails to augment production of nitric oxide (NO) by the pulmonary artery. The differences berween curves were not statistically significant. SA: surface area. 

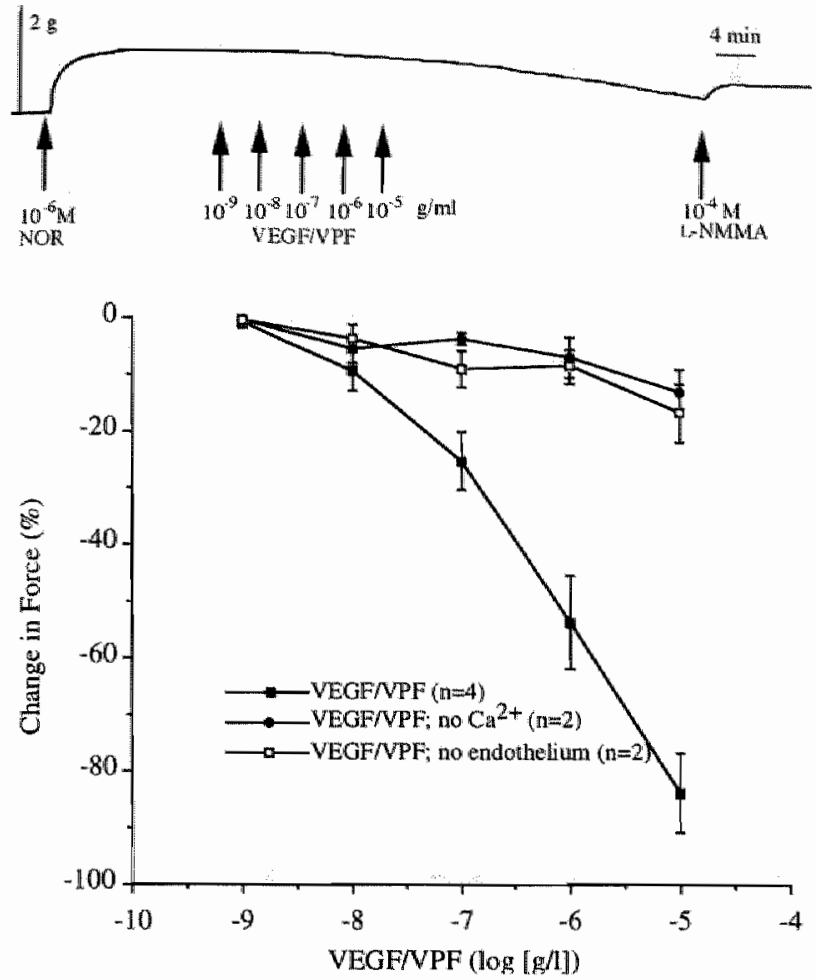

Figure 8. A. Representanve exmmple of vasorelaxacion in ring segnent of rabbit aora induced by vascular endothelial growth factor (VEGI)/ vascular permeability factor (VPli). Administration of $\mathrm{NG}^{\mathrm{G}}$-monomethyl-L-arginine (L NMMA) resulted in an immediate reversion of this effec. Both the response to $L-$ NMMA and the timecourse of relaxation are consistente with previous observations regarding VEGFNPF-induced $\mathrm{NO}$ release from the vascular wall.

B. Summated resuitrs of VEFFPPFinduced vasomotor reactivity. In absence of intact endothelium and/or $\mathrm{Ca}^{2+}$, vasorelaxation is severely attenuated. NOR: norepinephrin.

\section{Discussion}

These experiments establish that VEGF/VPF causes a dose-dependent increase of [NO] in vascular endorhelium. This increase in [NO] can be demonstrated in vascular segments harvested from different regions, including aorta, vena cava, and pulmonary artery, as well as from cultured human endorhelial cells. Parenthetically, these experiments also establish that ACh fails to enhance production of NO in both IVC and PA.

A variery of techniques have been previously employed to measure NO. NO production has been studied using a chemiluminescence assay; ${ }^{25}$ this approach measures the intensity of fluorescent radiation emitted after oxidation of $\mathrm{NO}$ by ozone. The use of this method for measurement of NO production by vascular segments in an organ chamber first requires reduction of $\mathrm{NO}_{2}{ }^{-}$back to $\mathrm{NO}$, and second transfer of $\mathrm{NO}$ from solution to gas. A limitation of this technique is that removal of NO from solution may introduce significant error at lower concentrations.

Kiechle et al reported an electrochemical method, based on registration of current, secondary to oxidation of NO. ${ }^{25}$ This technicue permits measurements to be made within short time intervals on the surface of the cell membrane, using electrochemical sensors with a diameter between 0.2 and $1.0 \mu \mathrm{m}$. A modification of this method was employed 

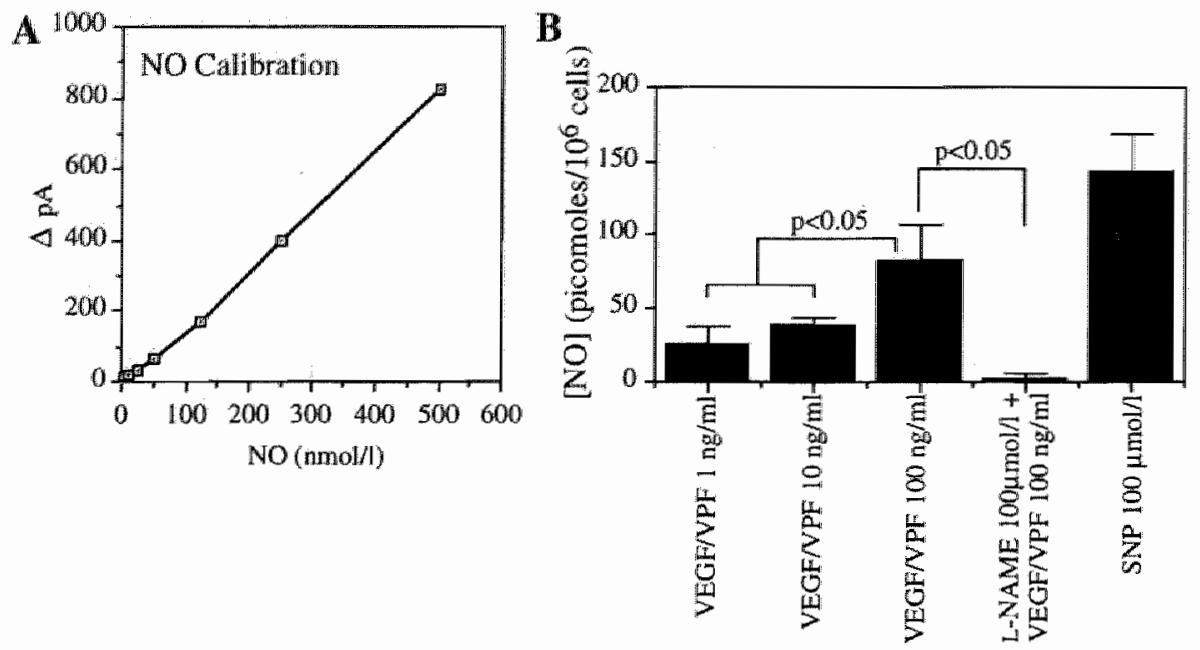

Figure 9. A. Standard calibration curve constructed with polarographic electrode employed for measurement of nitric oxide (NO) in cultured endothelial cells. B. Vascular endorhelial growth factor (VEGF)/ vascular permeabilicy factor (VPF) augments release of NO from human umbilical wein endothelial cells (HUVECs) in a dose-dependent fashion. This effect is abrogated by administracion of $\mathrm{N}^{\omega}$-nitro-Larginine methyl ester (L-NAME). Administration of an NO-donor (sodium nitroprusside, SNP) confirms the specificiry of the registered $\mathrm{NO}$ values. $\triangle \mathrm{p} A$ : differences expressed in pico-Amperes.

in the present study to measure NO release from cultured HUVECs treated with VEGF/VPF. The size of the sensor, however, restricts its use to measurements of NO release from cells, and is not applicable for NO registration from intact vascular segments.

In the current study, we therefore employed an alternative method, UV-visible spectrophotometry, which is relatively easy to perform, yields reproducible results, and allows measurements of significant differences of $[\mathrm{NO}]$ in the micromolar range from intact vascular segments. This approach is based on the premise that in common solutions [NO] is dependent upon the content of nitrogen oxides and nitrite:

$\mathrm{NO} \uparrow+\mathrm{NO}_{2} \uparrow+\mathrm{H}_{2} \mathrm{O} \leftrightarrow 2 \mathrm{HNO}_{2} \leftrightarrow 2 \mathrm{H}^{+}+2 \mathrm{NO}_{2}$.

The relationship between nitrous acid and nitrite is defined by:

$\mathrm{pH}-\mathrm{pK}=\log \left(\left[\mathrm{NO}_{2}^{-}\right] /\left[\mathrm{HNO}_{2}\right]\right)$.

In dilute solutions, the $\mathrm{pK} \approx 3.4$ at $37^{\circ} \mathrm{C}$. The experiments took place at $\mathrm{pH}=7.4$, implicating a 10,000-fold greater concentration of nitrite than nitrous acid. Assuming there is no $\mathrm{NO}$ or $\mathrm{NO}_{2}$ present in the Krebs solution before starting the experiments, an equation can be obtained to relare $\mathrm{NO}$ and $\mathrm{NO}_{2}$ : 
$\log [\mathrm{NO}]=$ constant $+\log \left[\mathrm{NO}_{2}^{-}\right]$.

Thus, the nitrite concentration we measured in samples taken from the organ chamber runs parellel to the concentration of $\mathrm{NO}$ :

$[\mathrm{NO}]=$ constant ${ }^{3} \cdot\left[\mathrm{NO}_{2}^{-}\right]$.

Since the fluid in the organ chamber is exposed to atmospheric oxygen, there is some loss of $\mathrm{NO}$ and $\mathrm{NO}_{2}{ }^{-}$to air and also via the glass walls of the organ chamber. Samples taken after removal of the NO-producing vessels of the organ chamber, demonstrated a decrease in nitrite concentration of about $10 \%$ after 15 min (data not shown). This explains both the decrease in $[\mathrm{NO}]$ after NO production was blocked by L-NMMA, as well as the horizontal curve produced by the vascular segments exposed to neither VEGF/VPF nor ACh.

$\mathrm{NO}$ is a colorless, free radical, simple gas with a half-life time of 10 to $30 \mathrm{sec}$. The heme-group of hemoglobin readily combines wirh $\mathrm{NO}$, yielding iron-nitrosyl adducrs and/or nitrate $\left(\mathrm{NO}_{3}{ }^{-}\right)^{26}$ Misko and colleagues found, using a fluorometric assay, that as little as $10 \mu \mathrm{mol} / \mathrm{l}$ hemoglobin completely abolished any signal representing nitrite. ${ }^{27}$ The merhodology employed in the current study likewise required removal of any blood which remained after harvesting the vessels. This, and handling of the excised vascular segments in a manner that avoids damaging the endothelium appear to be the two factors most responsible for minimizing variability in these types of experiments.

The onset for $[\mathrm{NO}]$ increase ( $4 \mathrm{~min}$ ), and the time required for VEGF/VPF to induce maximum release of $\mathrm{NO}(8 \mathrm{~min})$ were considerably longer than were observed for $\mathrm{ACl}$. It is interesting to note that a similar time frame ( 5 to $8 \mathrm{~min}$ ) was required for maximal relaxation of rings of thoracic aorta in the current study and isolared canine coronaries described previously by Ku et al. ${ }^{14}$ Furthermore, in vivo experiments recently performed in our own laboratory ${ }^{16}$ disclosed that the nadir of endorhelium-dependent hypotension occurred approximately $8 \mathrm{~min}$ after VEGF/VPF administration. The apparent reduction in NO producrion afrer $8 \mathrm{~min}$ may be a function of the brief half-life of VEGF/VPF, reported to be approximately $3 \mathrm{~min}$ (N. Ferrara, oral communication, August 1995).

The rapid onset of increased NO production after stimulation with $\mathrm{ACh}$ is inferred to represent the expedited consequence of a G-protein which is coupled to the $\mathrm{ACh}$ receptor. ${ }^{28}$

In contrast, VEGF/VPF binds to a non-G-protein coupled tyrosine kinase receptor Flt-1 and/or Flk-1/KDR, ${ }^{29,30}$ which must dimerize in order to activate downstream signaling. Tyrosine phosphate-mediated phosphorylation of phospholipase $\mathrm{C}_{\gamma-1}$, release of inositol 1,4,5-triphosphate from phosphoinositide, and a consequent increase in intracellular $\left[\mathrm{Ca}^{2+}\right]$, are presumed to constitute the basis for increased EC production of NO in response to VEGF/VPF. ${ }^{14}$ These different signaling parhways may account for the temporal differences observed for the onser of increased [NO] in response to $\mathrm{ACh}$ versus VEGF/VPF. 
VEGF/VPF caused an increase in [NO] in vascular segments from thoracic aorta, IVC, and pulmonary artery, implicaring the presence of of Flt-1 and/or Flk-l/KDR on endorhelial cells of all three vessel types. $\mathrm{ACh}$, however, failed to augment [NO] in either the IVC or PA, a finding which to our knowledge has not been reported previously. This observation might represent the explanation for findings recently reported by Gao et al, ${ }^{31}$ regarding failure of $\mathrm{ACh}$ to induce endothelium-dependent relaxarion in isolated pulmonary arteries of full-term fetal lambs; while ACh did induce relaxation in lambs 5 to 6 weeks in age, this effect could nor be abolished by an inhibitor of NO synthase. ${ }^{31,32}$ Similar observations were reported by Miller in isolated canine femoral veins. ${ }^{33}$ These differences in response to $\mathrm{ACh}$ may reflect a difference in muscarinic receptor density among different types of vessels. Moreover, activation of different muscarinic receptor subrypes are known to cause the release of different endothelial vasoactive factors. ${ }^{34}$

VEGF/VPF receptor expression is widespread during vasculogenesis and angiogenesis in the developing embryo. ${ }^{30}$ Postnatally, both the $F / t-1$ and $F / k-1 / K D R$ receptors have been shown to be upregulated at sites of recurrent neovessel proliferation, such as the corpus lutea of the ovary, ${ }^{10}$ or in pathologic tissues, ${ }^{35,36,37}$ particularly in conjunction with hypoxia. ${ }^{38,39}$ In contrast, expression of VEGF/VPF receptors by quiescent endorhelium in the adult has been considered to be typically reduced, ${ }^{30,35,36}$ and in some organs, such as the human adult brain, has been reported to be altogether absent. ${ }^{37}$ Peters er al, however, observed expression of Flt- 1 mRNA by quiescent endothelium of the adult mouse among multiple organs, including brain, corresponding to a similar partern of ${ }^{125} \mathrm{I}$-rthVEGF binding described earlier by Jakeman et al; ${ }^{10}$ these studies thus suggested that VEGF/VPF might have a function in mature vessels orher than mediating vascular growth.

The observation in the current study that VEGF/VPF stimulates production of NO when applied to endothelium-intact segments retrieved from three different vascular districts constitures inferential evidence for the presence of functional VEGF/VPF receprors on quiescent endothelium of the adult rabbit. The fact that this response is blocked by a competitive inhibitor of $\mathrm{NO}$ synthase suggests further that putative maintenance functions of VEGF/VPF may include regulation of baseline synthesis and/or release of $\mathbb{E C N O}$, and supports the notion of a "survival" or "maintenance/repair" role for VEGF/VPF."10,11,12 VEGF/VPF-induced recovery of disturbed endathelium-dependent flow in the rabbit ischemic hindlimb, ${ }^{15}$ for example, may reflect restored NO production by endothelial cells initially damaged by protracted ischemia in the collateraldependent limb.

NO has been implicared as an inhibitor of intimal thickening responsible for compromised arterial patency. ${ }^{40,41,42,43,44}$ De Meyer et al, for example, showed that the NO donor SPM-5185 could inhibit neointima formation and restore vascular reactivity in collared carotid arteries of rabbits, ${ }^{42}$ Von der Leyen et a ${ }^{43}$ likewise inhibited neointima formation in balloon-injured rat carotid arteries, and vascular reactivity in these vessels improved as well. ${ }^{44}$ More recently, Marks et al used a long-lived NO adduct to inhibit 
neointimal formation in injured rabbit arteries. ${ }^{42}$ VEGF/VPF, too, administered as the recombinant protein to the balloon-injured rat carotid artery, ${ }^{17}$ or as the CDNA to the balloon-injured rabbit femoral artery ${ }^{18}$ has been shown to inhibit intimal thickening. The results of these live animal studies in combination with the in vitro findings reported here, may be interpreted to suggest that $\mathrm{NO}$ is at least in part responsible for mediating this inhibitory effect of VEGF/VPF on intimal thickening.

The extent to which NO release may contribure to the proliferative and migratory roles of VEGF/VPF believed to be responsible for stimulating angiogenesis ${ }^{45,46}$ remains speculative. Leibovich et al ${ }^{47}$ found that the angiogenic activity of monocytes stimulated with lipopolysaccharide was borh $\mathrm{L}$-arginine-dependent, and inhibited by inhibitors of NO synthase. Recent work from our own laboratory has established that dietary supplements of L-arginine enhance angiogenesis in the rabbit model of hindlimb ischemia, ${ }^{48}$ consistent with a role for $\mathrm{NO}$ in promoting angiogenesis in vivo.

\section{Acknowledgements}

This study was supported in part by an Academic Award in Vascular Medicine (HL02824) and grant (HL-40518), both from the National Heart, Lung and Blood Institute, National Institutes of Health, Bethesda. MD. Dr. Van der Zee is a recipient of the Wijnand N. Pon Foundation Research Fellowship, Leusden, The Netherlands. Dr. Murohara is a recipient of the Uehara Memorial Foundation Research Fellowship.

\section{References}

1. Nishida K, Harrison DG, Navas JP, Fisher AA, Dockery S, Vermatsu M, Naren RM, Alexander RW, Murphy TJ. Molecular cloning and characterization of the consticurive boyine aortic endothelial cell nirric oxide synthase. / Clin Invest 1992,90:2092-2096

2. Rubanyi GM, Romero JC, Vanhoute $\mathrm{BM}$. Flow induced release of endothelium-derived relaxing factor. Am J Physiol 1986;250:41145-41149

3. La Montagne D, Pohl V, Busse R. Mechanical deformation of vessel wall and shear stress determine the basal release of endothelium-derived relaxing factor in the intact rabbit coronary vascular bed. Circ Res 1992;70:123-130

4. Pohl V, Holr J, Busse R. Bassenge E. Crucial role of endothelium in the wasodilator response to increased How in vivo. Hypertension 1986:8:37-44

5. Dinerman JL, Lowenstein CJ, Snyder SH. Molecular mechanisms of witric oxide regularion. Porential relevance to cardiowascular discase. Circ Res 1993;73:217-222

6. Keck PJ, Hauser SD, Krivi G, Sanko K, Warren T, Feder J, Conolly DT. Vascular permeability factor, an endorthelial cell mirogen related to PDGF. Science 1989;246:1309-1312

7. Leung DW, Cachianes G, Kuang W], Goeddel DV, Ferrana N. Vascular endothelial growth factor is a secreted angiogenic mitogen. Srience 1989;246:1306-1309

8. Plouer J, Schilling J, Gospodarowiza D. Isolation and chatacrerizarion of a newly identified endothelial cell micogen produced by ArT-20 cells. EMBOJ 1989;8:3801-3806 
9. Peters $\mathrm{KG}$, de Vres $\mathrm{C}$, Whlliams $\mathrm{LT}$. Vascular endothelial growh factor receptor expression during enbryogenesis and rissue repair suggesus a role in endorhelial differentiation and blood vessel growth. Proc Nat Acad So U \$A 1993,90:8915-8919

10. Jakeman LB, Whet J, Bennert GL, Altar CA, Ferrara N. Binding sites for vascular endothelial growt factor are localized on endothelial cells in adult rat tissues. J Clin Invest 1992;89:244-253

11. Alon 'T, Hemo I, Itin A, Pe'er I. Stone J, Keshet E. Vascular endothelial growth factor acts as a survival factor for newly formed retinal vessels and has implications for retinoparhy of prematuriry. Nature Med $1995: 1: 1024 \div 1028$

12. Shifren JL, Doldi N, Ferrara N, Mesiano S, Jaffe RB. In the human fetus, wascular endothelial growth factor is expressed in epithelial cells and myocytes, but nor vascular endothelium: implications for mode of action. J Clin Endocrin Metab 1994:79:316-322

13. Brock TA, Dworak HF, Senger DR. Tumor-secteted vascular permeability factor increases cytosolic $\mathrm{Cua}^{2 *}$ and von Willebrand factor release in human endothelial cells. An / Pathol 1991;138:213-221

14. Ku DD, Zaleski JK, Liu S, Brock TA. Vascular endothelial growth factor induces EDRF-dependent relaxation in coronary arteries. Am J Pbysiol 1993;265:-H586- 1592

15. Bauters C, Asahara T, Zheng LP. Takeshita S, Bunting S. Ferrara N, Symes JF, Isner JM. Recovery of disturbed endorhelium-dependent flow in the collateral-perfused rabbit ischemic hindlimb after administration of vascular endorhelial growth factor. Circulation 1995;91:2802-2809

16. Horowitz I. Harlawala $M$, Sheriff DD, Keyt B, Symes JF. In vivo administration of vascular endothelial growth factor is associated with EDRF-clependent systemic hypotension in porcine and rabbit animal models. Circulation 1995;92:1-630-1631. Abstract

17. Asahara T, Bauters C. Pastore CJ, Kearney M, Rossow S, Bunting S, Ferrara N, Symes JF, Isner JM. Local delivery of vascular endothelial growth factor accelerates reendorhelialization and artenuates intimal hyperplasia in balloon-injured rat carotid artery. Circulation 1995;91:2793-2801

18. Asahara T, Chen D, Kearney M, Rossow S, Passeri J, Symes Jf, Isner JM. Accelerated reendothelialization and reduced neointimal thickening following catheter transfer of phVEGF $165 . / \mathrm{Am}$ Coll Cardiol 1996;27:1A. Abstract

19. Hayashi T, Fullato LJ, Ignarro LJ, Chaudhuri G. Basal release of nitric oxide from aortic rings is greater in female rabbits than in male rabbits: implications for atheroselerosis. Proc Natl Acad Sci US A $1992 ; 89: 11259-11263$

20. Ignarro LJ, Buga GM, Wood KS, Byrns RE, Chaudhuri G. Endothelium-derived relaxing factor produced and releatsed from artery and vein is nitric oxide. Proc Nat Acad Sci U S A 1987:84:9265-9269

21. Callow AD. What's new in endorhelial cell biology and its clinical relewance? Curr Crit Prob Vasc Surg $1994 ; 10: 71-74$

22. Shibuki $K$, Okada D. Endogenous nitric oxide release required for long-term synapric depression in the cerebellum. Nature 1991;358:676-678

23. Weyrich AS, Ma X.I, Buerke M, Murohara T, Armstead VE, Lefer AM, Nicolas JM, Thomas AP, Lefer DI. Vinten-Johansen J. Physiological concentration of nitric oxide do not elicit an acure negative inotropic effect in unstimulated cardiac muscle. Circ Res 1994:75:692-700

24. Walter DH, Hink U, Asahara T, Van Belle E, Horowitz J, Tsurumi Y, Vandlen R, Heinsohn H, Keyt B. Fertara N, Symes JF, llsner JM. The in vivo bioactivity of vascular endorhelial growth factor/vascular permeability factor is independent of $\mathrm{N}$-linked glycosylation. Lab Invest 1996:74:546-556

25. Kiechle FL, Malinski T. Nitric oxide. Biochemistry, pathophysiology, and derecrion. Am J Clin Pathol $1993: 100: 567.575$

26. Stamler JS, Singel DJ, Loscalzo J. Biochenistry of nitric oxide and its redox-acrivated forms. Science $1992 ; 258: 1898-1902$

27. Misko TP. Schilling RJ, Salvemini D, Moore WM, Currie MG. A fluorometric assay for the measurement of nitrite in biological samples. Anal Brochers 1993;214:11-16

28. Brock TA, Capasso EL. Thrombin and histamine acrivate phospholipase $\mathrm{C}$ in human endotheliall cells via a phorbol ester-sensitive pathway. J Cell Physiol 1988;136.54-62 
29. de Vries, $\mathrm{C}$, Escobedo JA, Ueno H, Houck K, Ferram N, Williams LT. The fmsilike tyrosine kinase, a receptor for vascular endothelial growth factor. Science 1992:255:989-991

30. Millauer B, Wizigmann-Voos S, Schurch H, Martinez R, Mollier NPH, Risau W, Ulich A. High affinity VEGF binding and developmental expression suggests $F L_{-1}$ as a major regulator of vasculogenesis and angiogenesis. Call 1993;72:835-846

31. Gao $\mathrm{Y}$, Zhou $\mathrm{H}$, Raj JU. Heterogeneity in role of endothelium-detived NO in pulmonary arteries and veins of full-term fetal lambs. Am J Pbysiol 1995;265:H1586-H1592

32. Steinhorn RH, Morin III FC. Gugino SF, Giese EC, Russel JA. Developmental differences in endothelium-dependent responses in isolated ovine pulmonary arteries and veins. $A$ w $/$ Physiol $11993 ; 33: \mathrm{H} 677-\mathrm{H} 682$

33. Miller VM. Selective production of endothelium derived nirric oxide in canine femoral veins. A 4 ] Plyysiol 1991;261:H677-H682

34. Komori K, Suzuki $H$. Heterogenous distribution of muscarinic receptors in the rabbit saphenous artery. Br/ Pharmacol 1987;92:657-664

35. Dermar M, Brown LF, Claffey KP, Yeo K-T, Kocher O, Jackman RW, Berse B, Dvorak HF. Overexpression of vascular permeabilicy factor/vascular endothelial growth factor and its receptors in psoriasis. J Exp Med 1994:180:1141-1146

36. Brown LF, Berse B, Jackman RW, Tognazzi K, Guidi AJ, Dvorak HE, Senger DR, Conolly JL, Selnitr SJ. Expression of vascular permeability factor (vascular endothelial growth factor) and its receprors in breast cancer. Human Pathol 1995;26:86-91

37. Plate KH, Breier $\mathrm{G}$, Weich HA, Mennel HD, Risau W. Vascular endothelial growth factor and glioma angiogenesis: coordinate induction of VEGF receptors. Distriburion of VEGF protein and possible in vivo regullatory mechanisms. Int / Cancer 1994;59:520-529

38. Brogi E, Scharteman G, Wu T, Kim EA, Varticovski L, Keyt B, Isner JM. Hypoxia-ind wced paractine regulation of WEGF receptor expression. J Clin Invest 196;97:469-476

39. Tuder RM, Flook BE, Voelkel NF. Increased gene expression of VEGF and the VEGF receptors $\mathrm{KDR} / \mathrm{F} ! \mathrm{k}$ and $\mathrm{F} / \mathrm{t}$ in lungs exposed to acute or chronic hypoxia: modulation of gene expression by nitric oxide. J Clin Invest 1995;95:1798-1.807

40. Garg UC, Hassid A. Nitric oxide-generating vasodilators and 8-bromo-cyclic guanosine monophosphate inhibit mitogenesis and proliferation of cultured rat vascular smooth muscle cells. J Clin Invest 1989;83:1774-1777

41. Scotr-Burden T, Vanhoute PM. The endothelium as a regulator of vascular smoor muscle proliferation. Conculation 1993:87(suppl V): V-51-V-58

42. DeMeyer GRY, Bult H, Ustunes L, Kodk MM, Felisch M, Herman AG. Effer of nitric oxide donors in neointima formation and vasculat reacrivity in the collared carotid artery of rabbirs. / Cardiowatso Pharmatol 1995;26:272-279

43. von der Leyen HE, Leyen VD, Gibbons GH, Morishita R, Lewis NP, Zhang L, Nakajima M, Kanedat Y. Coole JP, Dzau VJ. Gene therapy inhibiting neointimal vaccular lesion: in wivo transfer of endorhelial cell nitric oxide synthase gene. Proc Narl Acad Sci U S A 1995:92:1137-1141

44. Marks DS, Vita IA, Folts JD, Kearney JF, Welch GN, Loscalzo J. I uhibition of neointimal proliferation in rabbits after vascular surgery by a single treatment with a protein adduct of nicric oxide. J Clina lnwest $1995 ; 96: 2630 * 2638$

45. Folkman J, Klagsbrun M. Angiogenic factors. Science 1987;235:442-447

46. D'Amore PA. Thompson RW. Mechanisms of angiogenesis. Annu Reu Physol 1987:49:453-464

47. Leibowich SJ, Polverini PJ, Fong TW, Harlow LA, Koch AE. Production of angiogenic activiry by human monocytes requires an L-arginine/nitric oxide-synthase-dependent effector mechanism. Iyrot Nat Acad Sct US A 1994;91:4190-4194

48. Asahara T, Bauters C, Wu T, Zheng LP, Chen D, Symes J, Isner JM. Nirric oxide precursor alugments angiogenesis and attenuates endorhelial dysfunction in collateral circulation in rabbir ischemio hindlimb in wivo. FASEB / 1996;10:A545. Abstract 



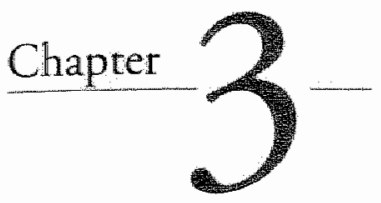

\section{The human internal mammary artery releases more nitric oxide in response to vascular endothelial growth factor/vascular permeability factor than the human saphenous vein.}

Evidence for VEGF/VPF-receptors in quiescent human endothelium.

Rien wan der Zee, MD; Jonathan Passeri, BA; Jeffrey R. Horowitz, BS;

James F. Symes, MD; Jeffrey M. Isner, MD

From the Departments of Biomedical Research, Medicine (Cardiology), and Surgery (Cardiovascular), St. Elizabeth's Medical Center, Tufts University, School of Medicine, Boston, Mass 02135

Rien wan der Zee is a recipient of a traveling grant of the Wynand N. Pon Foundation.

Submitted as full paper; accepted as abstract in Circulation 1997. 


\section{Abstract}

Intimal thickening is an importan cause of late coronary vein graft octhsion. The internal mammary artery (IMA) graft bas been shown to bave a betwer long-term patency than the vein graft, which might reflect a bigher release of endothetial cell (EC) nitric axide (NO). We therefore sought to determine to which extert vascular endothelial growth factorivascular permeability factor (VEGF/VPF) augments NO release in vascular segments of the buman IMA and saphenows vein $(S V)$, fresbly barvested from patients undergoing coronary bypass surgery.

The vessel segments were placed in an organ chamber. NO was determined using photospectrometry on small samples taken from the organ chamber solution that subsequently were reacted with Gretss solution. For some experiments the vascular segments were bomogenized for Western blotting.

We found that the NO production in the IMA was 2-fold bighe than whe SV. In addition, VEGF/VPF augmented NO production in both types of wessels by approximately 50\%. This effect was abrogated by co-administration of an inhibitos of nitric axide synthase (NOS), by mechanical disruption of the endothelium, and by removal of calcum from the organ bath solution, thus providing evidence for the involvement of the calcum-sensivive EC constitutive NOS.

These results were supported by Western bloting of the harvested vascular segments, showing, to our knowledge for the first times the expressian of the VEGFVPF-receptors KDR(Flk-1) and Flt-1 on quiescent mature buman endothelitum. The receptor density of the IMA was approximately 2-fold bigher than in we $5 \mathrm{~V}$.

In conclusion, the VEGF/VPFreceptors KDR(F/k-1) and Flt-1 are expressed on quiescent endothelium of buman coronary bypass grafts. and VEGFIVPF angments $E C N O$ release in the buman IMA and SV. 
Intimal thickening is an important cause of late coronary vein graft occlusion. ${ }^{1,2}$ The internal mammary artery (IMA), however, has been shown to have a much better long-term patency when this vessel is used as a conduit for coronary artery bypass. ${ }^{3}$ Lüscher and colleagues have suggested that the difference berween endothelium-dependent relaxation in arterial and venous bypass grafts is due to a higher release of nitric oxide (NO) in the IMA. ${ }^{\text {f }}$

The NO produced in the endorhelium exerts many putative features. Endorheliumdependent vasorelaxation is mediated by $\mathrm{NO}$, a potent acrivator of soluble guanylate cyclase, which causes increased intracellular levels of cyclic GMP and subsequently smooth muscle relaxation. ${ }^{5,6}$ Furthermore, $\mathrm{NO}$ has an inhibitory effect on cell proliferation and adhesion, effects that are also mediared by increased levels of cyclic GMP. ${ }^{7}$ It has been reported, that $\mathrm{NO}$ reduces vascular smooth muscle cell mitogenesis. $8,9,10$ Plarelet and leukocyte adhesion to the vascular endothelium and subsequent chemotaxis are also negatively regulated by NO. ${ }^{11,12,13}$ More support for the protective actions of $\mathrm{NO}$ was provided by Cooke and colleagues who documented the antiatherogenic effects of $\mathrm{L}$-arginine, the precursor of $\mathrm{NO}$, in hypercholesterolemic rabbits $^{14,15}$ and humans. ${ }^{16}$

Recently, experiments in our own laboratory showed that the production of $\mathrm{NO}$ in quiescent rabbit vascular endothelium from arteries was significantly higher than in veins. ${ }^{17}$ In addition, vascular endothelial growth factor/vascular permeability factor (VEGF/VPF) augmented $\mathrm{NO}$ release in arteries more than in veins.

VEGF/VPF is a $45 \mathrm{kD}$ heparin-binding dimeric glycoprotein that has been reported to induce mitogenesis of endothellial cells, but not in other cell types. ${ }^{18,19,20}$ Because of the unique aspect of its narrow target cell specificity, VEGF/VPF has a crucial role in endothelial cell differentiation and consequently is obligatory for normal development of the vasculature in mammalian embryos. ${ }^{21,22}$

The expression of VEGFNPF receptors by quiescent endothelium in the aciult, however, has been considered to be reduced or absent. 23,24 Therefore, in the present study we sought to determine to which extent VEGF/VPF may stimulate NO production in freshly isolated segments of human IMA and the saphenous vein (SV), since a ligandreceptor interaction can be inferred from an augmented $N O$ release. In addicion, to further address the issue of Flk-I/KDR and Fli-I receptors on adult quiescent endothelium, the expression of $\mathrm{MRNA}$ of VEGF/VPF and its receptors in both types of human vessels is assessed by reverse transcriprase-polymerase chain reaction (RT-PCR) and Western blotting. 


\section{Materials and methods}

\section{Vessel preparations}

Experiments were performed on wessels isolated from 15 parients undergoing coronary artery bypass grafting for the first time after informed consent was obtained. The preparation of the vessels was conducted as described previously in rabbits. ${ }^{15}$ In short, immediately after excision of the SV and IMA segments, the vessels were washed with a phosphate-buffered solution (PBS). Connective and other adhesive tissue was completely removed. Then, the vascular segments were placed in an organ chamber and washed again in Krebs solution (in mMol/L: $118 \mathrm{NaCl}, 4.6 \mathrm{KCL}, 27.2 \mathrm{NaHCO}_{3}, 1.2 \mathrm{MgSO}, 2.5$ $\mathrm{CaCl}_{2}, 1.2 \mathrm{KH}_{2} \mathrm{PO}_{4}, 11.1 \mathrm{gllucose}, \mathrm{pH} 7.4$ ), aerated with a $95 \% 0_{2}-5 \% \mathrm{CO}_{2}$ gas mixture, and maintained at a constant temperature of $37^{\circ} \mathrm{C}$. When necessary, the segments were cut at $5 \mathrm{~mm}$ intervals to ensure optimal exposure of the endothelium ro oxygen and reagents added to the organ chamber. For some experiments, the endothelium was mechanically removed by rubbing the interior of the vessel rings with a wetted cotton swab. Fifteen minutes before administration of the reagents ( $t=-15$ min) the fluid in the organ chamber was replaced to remove any remaining hemoglobin. The reagents were administered at $\mathrm{t}=0 \mathrm{~min}$ in a concentrated fashion to avoid significant dilution of the $\mathrm{NO}$ or nitrite $\left(\mathrm{NO}_{2}\right)$ concentration in the organ bath solution. PBS was added for negarive control experiments. For a positive control acerylcholine was used.

\section{Measurement of NO}

NO was determined at different points in time before and after administration of the reagents to be tested. For each timepoint a $0.7 \mathrm{~mL}$ aliquot was taken out of the organ chamber and added to a $1 \mathrm{~mL}$ cuvette with an optical path of $1 \mathrm{~cm}$, prefilled with 0.07 $\mathrm{mL}$ of Griess solution ( $1 \%$ sulfanilic acid, $0.1 \%$ naphthalene-cthylene diamine in $5 \%$ $\mathrm{H}_{3} \mathrm{PO}_{4}$ ). Naphthallene-ethylene diamine reacts with both $\mathrm{NO}$ and $\mathrm{NO}_{2} ;$ the products renders the solution in the cuvetre pink. This color displays a spectrophotometric peak at $548 \mathrm{~nm}$. The absorbance at $548 \mathrm{~nm}$ was determined with a diode array phorospectrometer (8452A, Hewlet Packard, Andover, MA) and was translated into NO concentration using a standard curve, which was linear from 0.03125 to $0.25 \mu \mathrm{mol} / \mathrm{L}$. $\mathrm{NO}_{2}$. As a blank, Krebs solution, which had not been exposed to the vascular segments, mixed with Griess solution in a similar fashion, was used.

\section{Drugs}

Heterodimeric recombinant human VEGF/VPF, purified from Escherichia Coli, was a gift of Napoleon Ferrara and Stuart Bunting, Genentech, South San Fransisco, CA. All chemical components were obtained from Sigma Chemical (St. Louis, MO). Primary antibodies for Western blot analysis were monoclonal goat anti-human $F / k-I$ and $F l t-I$ 
antibody (Santa Cruz Biotechnology, Santa Cruz, CA), and monoclonal goat anti-human VEGF/VPF antibody (R\&D System, Minneapolis, MN). All used antibodies have been shown to be specific for the tested receptors.

\section{RT-PCR procedures}

Total RNA was extracted from homogenized vascular segments by phenol/ chloroform extraction, ${ }^{25}$ and RNA concentration was calculated from the absorbance at $260 \mathrm{~nm}$. Control experiments were performed on human umbilical vein endothelial cells (HUVECs) for KDR/Flk-1, Flt-1, and glyceraldehyde phosphate dehydrogenase (GAPDH). Humbilical vein smooth muscle cells (HVSMCs) were used as a control for VEGF/VPF.

Approximately $1 \mu \mathrm{g}$ of RNA was reverse transcribed using the Promega reverse transcription system (Promega, WI) for 1 hour at $42{ }^{\circ} \mathrm{C}$. PCR was performed using primers to $F l t-1, K D R / F l k-1, \mathrm{VEGF} / \mathrm{VPF}$, and GAPDH, which functioned as a control. PCR was performed with $2 \mu \mathrm{l} \mathrm{cDNA}$ in the presence of $500 \mathrm{ng}$ of each primer and 0.2 $\mathrm{mMol} / \mathrm{L}$ dNTPs in a total volume of $50 \mu \mathrm{l}$. Following a hot start $\left(96^{\circ} \mathrm{C}, 8 \mathrm{~min}\right) 1 \mathrm{U}$ of DNA polymerase (Clontech, Palo Alto, CA) was added at $56^{\circ} \mathrm{C}$ and amplified for 30 cycles under the following conditions: $94^{\circ} \mathrm{C}, 1 \mathrm{~min} ; 56^{\circ} \mathrm{C}, 1 \mathrm{~min} ; 72^{\circ} \mathrm{C}, 2$ min. Products were resolved on $1 \%$ agarose gels and visualized by UV illumination following ethidium bromide staining. The paired primer sequences used were as follows (sense/antisense): for KDR/Flk-1, 5'-GGA AAT CAT TAT TCT AGT AGG CAC GAC G/5'-CCT GTG GAT ACA CTT TCG CGA TG (819 bp PCR product); for Flt-1, 5'-GCA CCT TGG ITG TGG CTG AC/5'-CGT GCT GCT TCC 'TGG TCC (735 bp); for VEGF/VPF, 5'-CCT GGT GGA CAT CTT CCA GGA GTA CC/5'-CTC ACC GCC TCG GCT TGT CA $(438,570$, and 642 bp); for GAPDH, 5'-TGA AGG TCG GAG TCA ACG GAT TTG/5’-CAT GTG GGC CAT GAG GTC CAC CAC ( 983 bp).

\section{Western blot procedures}

The vessel segments were cut into small pieces and rreated with lysis buffer containing protease inhibitors (PMSF, Pepstatin A, Aprotinin, and Leupeptin). For positive controls umbilical veins were used, for negative controls umbilical veins after removal of endorhelial layer (data not shown). The tissue was homogenized, centrifuged $(15,000 \mathrm{~g}$, $20 \mathrm{~min}, 4^{\circ} \mathrm{C}$ ), boiled, and centrifuged again. The supernatants were collected and protein concentrations were calculated using bovine serum albumin (BSA) as a standard. After loading of equal amounts per lane, proteins were separated by gel-electrophoresis and transferred onto $0.2 \mu \mathrm{Mol} / \mathrm{L}$ PVDF-membranes (Bio-Rad Laboratories, Hercules, CA) in $25 \mathrm{mMol} / \mathrm{L}$. Tris, $200 \mathrm{mMol} / \mathrm{L}$ glycine, $1.3 \mathrm{mMol} / \mathrm{L}$. SDS, and $20 \%$ methanol at 30 $\mathrm{mA}$ for 3 hours. The membranes for detection of other proteins were incubated with $₫ 0 \%$ dry milk for 1 hour. Each membrane was incubated with a primary Flk-1 or KDR/(Flt-1) antibody solution (1:100 dilution) at $4^{\circ} \mathrm{C}$ overnight. For a negative control non-immune 
goat $\mathrm{IgG}$ was used. Then, biotinylated horse anti-goar immunoglobulin was applied, followed by incubation with streptavidin-horseradish peroxidase. Images were obtained on X-ray film using the ECL-kit (Amersham Life Science, Arlington Heights, IL).

\section{Calculations and statistical analysis}

The increase in $\mathrm{NO}$ in the organ bath solurion caused by sampling-induced decrease in volume of the organ chamber in the presence of a NO-producing source was corrected for according to the formula:

$\left.\mathrm{C}_{\mathrm{t}}=\mathrm{C}_{\mathrm{x}-2}+\left(\mathrm{C}_{\mathrm{t}}-\mathrm{C}_{\mathrm{x}-2}\right) \cdot\left(\mathrm{V}-\pi \cdot \mathrm{V}_{\mathrm{s}}\right) / \mathrm{V}\right)$

in which $C_{t}$ is the $N O$ concentration at time $t=t \mathrm{~min} ; \mathrm{x}=15 \mathrm{~min} ; \mathrm{V}$ is the initial volume in the organ chamber (i.e. $10 \mathrm{~mL}$ ); is the number of sampling times; and $V_{3}$ is the sampling volume (i.e. $0.7 \mathrm{~mL}$ ).

To correct for the differences in size of the vascular segments, the NO production was standardized for surface area (SA). The NO concentration ([NO]) per SA in $\mu \mathrm{Mol} / \mathrm{L} \cdot \mathrm{m}^{2}$ was documented, assuming that the production of $\mathrm{NO}$ was equal across the entire endothelium.

Values are given as means \pm standard error $(\mathrm{m} \pm \mathrm{SEM})$. If $\mathrm{n}=2$, bars indicate the range of obtained values. The data were evaluated using a 2 -facrorial (significance over time, significance of drug effect) analysis of variance (ANOVA) for repeared measurements. Statistical significance was inferred when $p<0.05$. In all experiments, $n$ equals the number of vessels that were used.

\section{Results}

\section{NO measurements}

The baseline production of NO in the arterial segments was observed to be significantly higher than in the venous segments (Figure 1). In addition, after administration of VEGF/VPF a significant increase in NO release in both the IMA and SV was documented. Interestingly, both vessels displayed a maximal value after $8 \mathrm{~min}$, reflecting the time necessary for downstream signaling after ligation of the VEGF/VPF receptors. ${ }^{26,15}$

Addition of L-arginine, the substrate for nitric oxide synthase (NOS), to the organ bath sollution resulted in an increase of $\mathrm{NO}$ production by approximately 2-fold (Figure 2). Likewise, co-administration of $\mathrm{NG}^{\mathrm{G}}$-monomethyl-L-arginine (L-NMMA), an inhibitor of NOS, torally abrogated the response to VEGF/VPF and decreased the baseline NO production.

Mechanical disruption of the endothelium also prevented a rise in NO production after administration of VEGF/VPF, implicating that intact endothelium is mandatory 


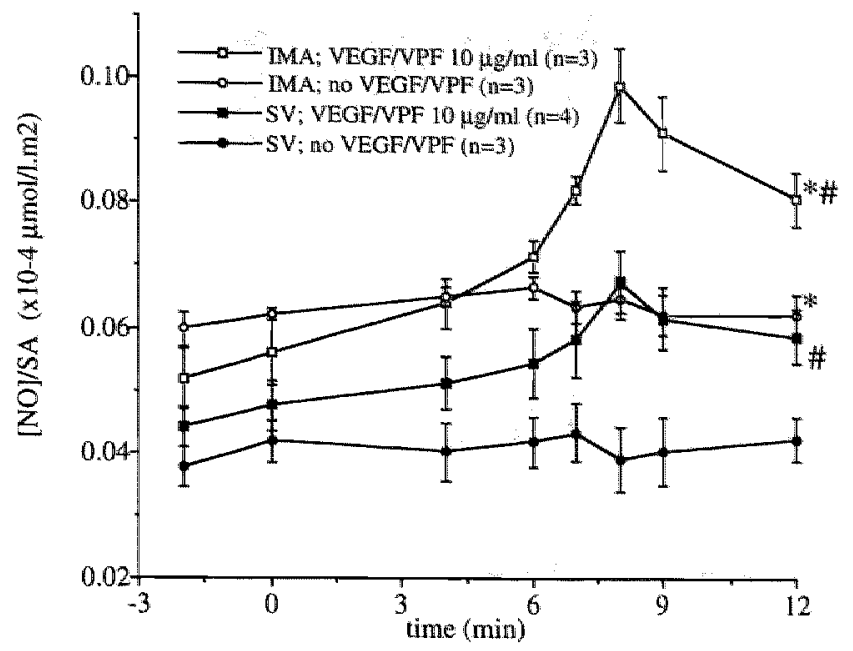

Figure 1. NO production in the human internal mammary artery and the human saphenous vein. IMA: internal mammary artery; $S \mathrm{~V}$ : saphenous vein; VEGF/VPF" vascular endorhelial growth factor/vascular permeability factor; $S A$ : surface area; *: $p<0.05$ versus "IMA; no VEGF/VPF; \#" $p<0.05$ versus 'SV; no VEGFNPF".

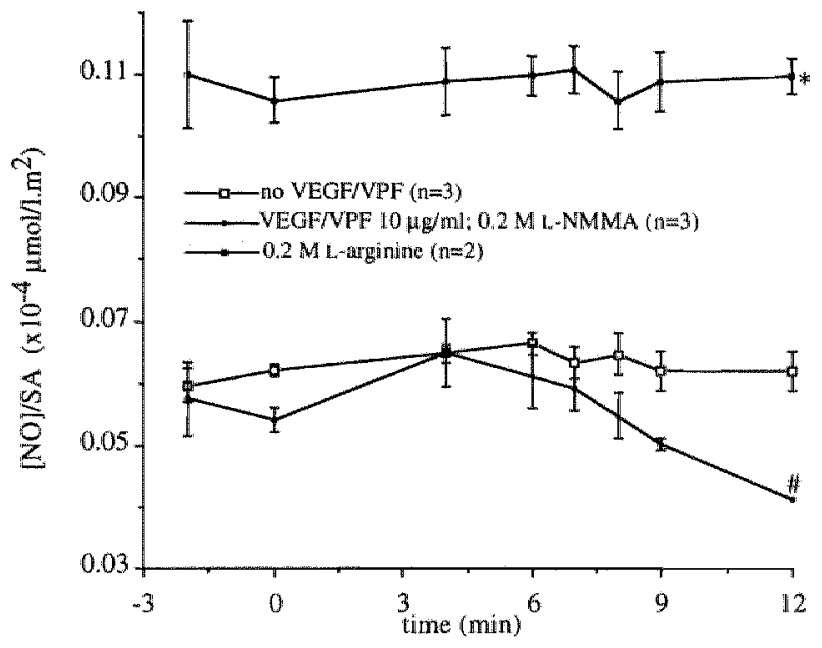

Figure 2. NO producrion in the human internal mammary artery. VEGF/VPF: vascular endorhelial growth faccor/vascular permeability factor; L-NMMA: NG. monomethyl-L-arginine; SA: surface atea; ": $p<0.05$ versus "no VEGF/VPF"; $\mathrm{p}<0.05$ versus "no VEGF/VPF' at $\mathrm{t}=12 \mathrm{~min}$. 


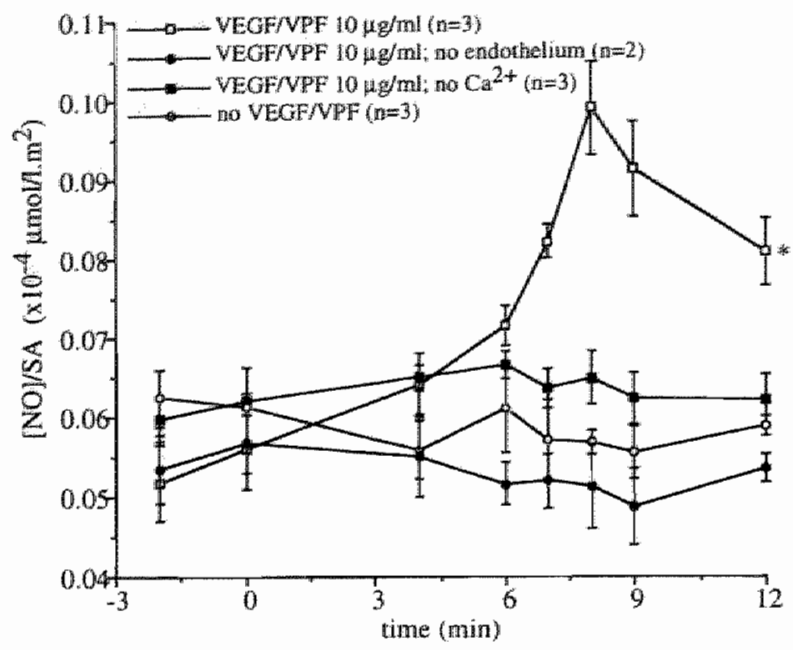

Figure 3. NO production in the human intemal mammary artery. VEGF/VPF: vascular endothelial growth factor/wascular permeabillicy factor; $S A$ : surface area; *: $p<0.05$ wersus all other curves.

for this growth factor to exert its action (Figure 3). In addition, removal of $\mathrm{Ca}^{2+}$ from the organ bath solution also abolished an increase in $\mathrm{NO}$ production. This observation is supportive for the notion that the calcium sensitive endorhelial consriturive NOS (ec-NOS) is involved in the documented NO release, as opposed to the calcium insensitive inducible NOS (i-NOS), which can be expressed in other cell types of the vascular wall.

In the SV similar results were registered (Figure 4). Interestingly, after administration of $L$-arginine the baseline $\mathrm{NO}$ production increased to levels observed in the artery.

\section{RT-PCR/Western blot}

The expression of the receptor tyrosine kinase gene $K D R(F / k-1)$ and the fms-like tyrosine kinase Flt $I$ in human adult vessel segments of both artery and vein is demonstrated (Figure 5a), an observation which, to our knowledge, has not been reported before. Furthermore, the expression of VEGF/VPF is recorded in both types of vessels, thus providing the constituents for a paracrine loop. The documented expression of both receptors and their ligand is supporrive for the concept that VEGF/VPF augments NO release by mature quiescent endothelium.

Both $K D R$ and Fit-1 proteins were present in the vascular wall of both vessel rypes (Figure 5b). However, Western blotring revealed a higher receptor density in the IMA 


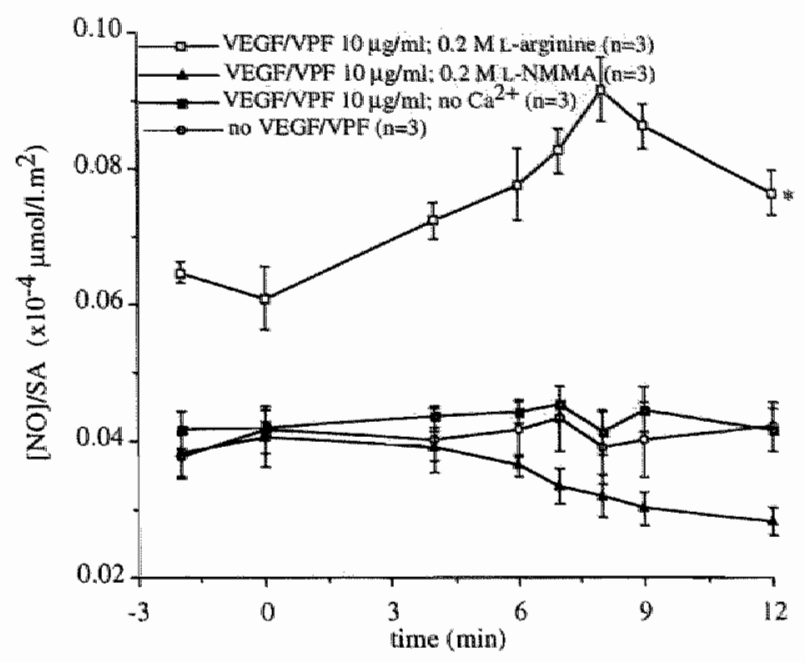

Figure 4. NO production in the human saphenous vein. VEGF/VPF: valscular endothelial growth factor/vascular permeability factor; SA: surface area; L-NMMA: $\mathrm{N}^{\mathrm{G}}$-monomethyl-L-arginine; $\mathrm{p}<0.05$ versus all orher curves.

(a)

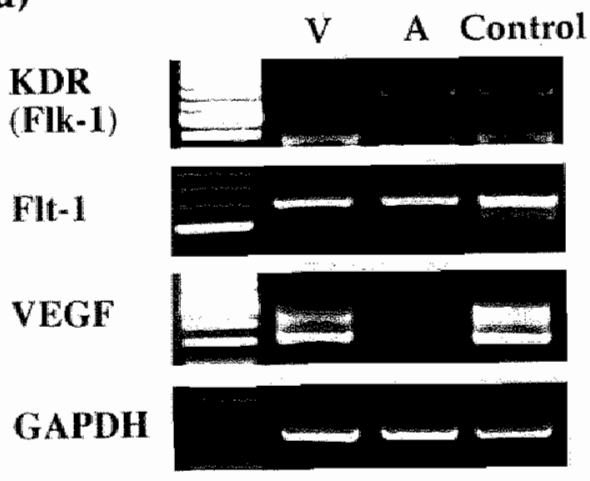

(b)

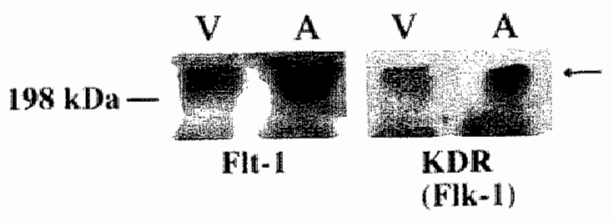

Figure 5. A) RT-PCR demonstrates KDR(Flk-1), Flt-1, and VEGF/VPF mRNA in isolated segments of human internal mammary artery $(A)$ and human saphenous vein (W); $\mathrm{n}=3$, CDNA for positive control is shown in lane 4. VEGF: vadscular endorhetial growth factor: lane 1: weight matker channel; GAPDH: glyceraldehyde phosphate dehydrogenasc.

Figure 5. B) Westem blot shows expression of

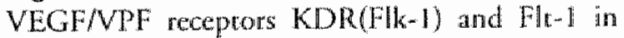
normal human saphenous wein (V) and human internal mammary artery (A) vessel segments; $n=3$. 
for both VEGF/VPF receptors compared to the SV. This is in concordance with the observed higher baseline NO production by the artery.

\section{Discussion}

From these experiments it has been concluded that VEGF/VPF is capable of inducing a significant increase in NO release by both human IMA and SV. Furthermore, additional evidence is provided for the expression of the tyrosine kinase receptors $K D R(F l k-l)$ and $F(t-1$ as well as for the ligand VEGF/VPF by identification of the involved m-RNA and protein expression. The receptor density in the mammary arteries is higher than in the saphenous veins.

Constiturive release of $N O$ from vascular endothelial cells has been shown to be crucial in preserving the integrity of a blood vessel. The simple molecule NO mediates a great number of phenomena in vascular biology, including endothelium-dependent vascular relaxation, ${ }^{5,6}$ endothelial permeabiliry, ${ }^{27,28}$ inhibition of platelet aggregation, ${ }^{9,10}$ and inhibition of leukocyte achesion by modulating the gene expression in endothelial cells of vascular cell adhesion molecule-1. 13,2\% The registered baseline $\mathrm{NO}$ release in arteries exceeds the venous NO production by approximately $50 \%$, which might be an explanation for the superior long-term parency of IMA grafts. This observation warrants additional investigations as to the NO production of grafts that have been used as a conduit for a longer period of time.

From this study it can be concluded that VEGF/VPF augments NO production when ligated to its receptors $F l k-1 / K D R$ and $F / t-I$, uniquely present on endothelial cells. Accordingly, mechanical disruprion of the vascular endothelium totally abrogated the response to VEGF/VPF. Endothelial cells contain nitric oxide synthase (ec-NOS), which constitutes a membrane-bound complex with calmodulin, thus becoming sensitive to cytosolic calcium fluctuations. ${ }^{30}$ This complex is involved in the conversion of $\mathrm{L}$-arginine to citrullin, yielding NO. ${ }^{31}$ VEGF/VPF binds to its tyrosine kinase receptors, which must dimerize to activate downstream signaling: ${ }^{32}$ phosphorylation of phospholipase $\mathrm{C}_{\gamma-1}$, causing the release of inositol-tri-phosphate ( $\mathrm{IP}_{3}$ ) resulting in an increase in cytosolic $\mathrm{Ca}^{2+}$, and a subsequent increase of ec-NOS activity and NO production. ${ }^{26}$ Consistent with this mechanism is the observation that removal of $\mathrm{Ca}^{2+}$ from the organ bath solution abolishes the increase in NO production after VEGF/VPF administration.

The role of VEGF/VPF in adult human blood vessels still needs to be clarified. VEGF/VPF was originally discovered as a result of its ability to increase permeabilty of vascular endothelium ${ }^{33}$ and to induce endorhelial cell mitogenesis. ${ }^{34}$ VEGF/VPF has been reported to be mandatory in the normal development of the vasculature of mammalian embryos. ${ }^{21,22}$ The tight temporal and spatial regulation of VEGF/VPF $m$ RNA expression, together with the ubiquitous nature of receptor binding to endorhelial and preendothelial cells is documented by Jakeman ${ }^{35}$ and Breier. ${ }^{36}$ Postnatally, however, 
both Flt-l and Flk-I/KDR receptors have been shown to be upregulated only at sites of recurrent neovessel proliferation, such as the corpora lutea of the ovary, ${ }^{37}$ or in pathologic conditions like psoriasis and tumor formation, ${ }^{38,39}$ especially in conjunction with hypoxia. $40,41,42$ In contrast, expression of VEGF/VPF receptors by quiescent endorhelium is reduced in the adult, ${ }^{23}$ or in some organs, such as the human adult brain, alrogether absent. ${ }^{24}$

In this study, the expression of both VEGF/VPF and its receptors in combination with an increase in NO production after VEGF/VPF administration in both rypes of adult human vessels is documented. This observation suggests that in healthy, mature vessels the biological function of this growth factor is not limited to angiogenesis. Preservation of an intact barrier between circulating blood and the vessel wall constitutes a critical condition for normal vessel behavior. Throughout life, blood vessels are exposed to local expression and/or infiltration by cytokines, proteases, oxidative stress and other factors that may damage or impair endorhelial function. ${ }^{4,43}$ Under these circumstances VEGF/VPF-augmented NO production may be required for recurrent repair of damaged or dysfunctional endothelium, thus protecring the vessel from thrombotic events, ${ }^{11,12}$ leukocyte adhesion, ${ }^{13}$ and/or vasospasm. ${ }^{5,6}$ In addition, intacr funcrional endothelium is mandatory to inhibit medial smooth muscle cell proliferation. ${ }^{8,9,44}$ This feature is relevant to the preservation of vascular patency as well, since migration of proliferating medial smooth muscle cells has been shown to contribute to the occurrence of intimal thickening in coronary bypass grafts and native coronary arteries. ${ }^{1,4}$ Therefore, these data support the concept that the physiological function of VEGF/VPF in mature vessels involves maintenance and/or repair of the luminal endothelium by augmenting endothelial cell NO production.

\section{References}

1. Yang Z, Luscher TF. Basic cellular mechanisms of coronary bypass graft discase. Lur Heart 1993:14(suppl1):193-197

2. Predel HG, Yang $Z$, von Segesser $L$, Turina M, Buhler FR, Luscher TF. Implications of pulsatile streth on growth of saphenous vein and mammary arcery smooth muscle. Lancet 1992;340:878-879

3. Fitzgibbon GM, Kafka HP, Leach AJ, Keon WJ, Hooper GD, Burton JR. Coronary loypass graft fare and patient outcome: angiographic follow-up of 5,065 grafts related to survival and reoperation in 1,388 patients during 25 years. J Am Coll Cardiol 1996;28:616-626

4. Lüscher TF, Tanner FC, Tschudi MR, Noll $G$. Endothelial dysfunction in coronary artery disease. Annu Rev Med 1993;44:395-418

5. Furchgort RF, Zawadzki JV. The obligatory role of endothelial relaxarion of arterial smooth muscle by acerylcholine. Nature 1980;288:373m376

6. Palmer RMJ, Ferrige AG, Moncada S. Nitric oxide release accounts for the biological acrivity of endorhelium-derived relaxing factor. Nature 1987;327:524-526

7. Lowenstein Cl, Dinerman JL, Snyder SH. Nitric oxide: a physiologic messenger. Ann Intern Med $1994: 120: 227-237$ 
8. Garg LC, Hassid A. Nitric oxide-generating vasodilators and 8xbromo-cyclic guanosine monophosphate inhibit mitogenesis and proliferarion of cultured rat vascular smooth muscle cells. I Clin Invest 1989:83:1774-1777

9. Scott-Burden T, Schini VB, Elizondo E, Junguero DC, Vanhoutte PM. Platejet-derived growth factor suppresses and fbroblast growth factor enhances cyrokine-induced production of nirric oxide by Eultured smooth muscle cells: effects on cell proliferation. Circ Res 1992;71:1088-1100

10. Cooke J P, Singer AH, Tsao P, Zera P, Rowan RA, Billingham ME. Antiatherogenic effects of L-arginine in the hypercholesterolemic rabbit. J Clin Invest 1992;90:1168-1172

11. Radomski MW, Palmer RMJ, Moncada S. An L-arginine/nirric oxide pathway present in human platelers tegulates aggregation. Proc Naxt Acad Sci U S A 1990;87:5193-5197

12. Radonski MW, Palmer RMI, Moncada S. Endogenous nitric oxide inhibits human platelet adhesion to vascular endothelium. Lancet 1987;2:1057-1058

13. Kubes P. Suzuki M, Granger DN. Nitric oxide, an endogenous modularor of leukocyte adhesion. Proc Natl Acad Sc USA 1991;88:4651-4655

14. Cooke $\mathrm{P}$, Singer AH, Tsao P, Zera P, Rowan RA, Billingham ME. Antiatherogeniceffects of L-arginine in the hypercholesterolemic rabbit. / Clin Invest 1992;90:1168-1172

15. Wang BY, Singer AH, Tsuo PS, Drexler H, Kosek J, Cooke IP. Dietary arginine prevents arherogenesis in the coronary artery of the hypercholesterolemic rabbit. J Am Coll Cardiol $1994: 23: 452-458$

16. Creager MA, Gallagher S], Girerd XJ, Coleman SM, Dzau VJ, Cooke JP. L-arginine improves endothelium-dependen vasodilation in hypercholesterolemic humans. I Chin Invest 1992,90:12481253

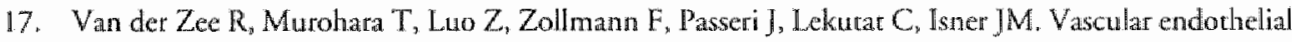
growth factor/vascular permeability factor augments nitric oxide release from quiescent rabbir and human vascular endothelium. Cinculation 1997:95:1030-1037

18. Leung DW, Cachianes $\mathrm{G}$, Kuang W-J, Goeddel DV, Ferrara N. Vascular endorhelial growth factor is a secreted angiogenic mitogen. Science 1989;246:1309-1312

19. Olander JV, Connolly DT, DeLarco JE. Specific binding of vascular permeability factor to endothelial cells. Buocbew Brophys Res Commun 1991;175:68-76

20. Ferrara $N_{n}$ Henzel WJ. Pituitary follicular cells secrete a novel heparin-binding growth factor specific for vascular endothelial cells. Biochem Biophys Res Commun 1989;161:851-857

21. Carmeliet P. Ferreira V, Breier G, Pollefeyt S, Kieckens $L$, Gersenstein M, Fahrig M, Vandenhoeck A, Harpal K, Erberhardr C, Dederq C, Pawling J, Moons L, Collen D, Risau W, Nagy A. Abnormal blood vessel development and lethality in embryos lacking a single VEGF allele. Narme 1996:380:435439

22. Shataby F, Rossant J, Yamaguchi TP, Gertsenstein M, Wu XF, Breiman ML, Shuh AC. Failure of blood-island formation and vasculogenesis in Flk-J-deficienc mice. Name 1995;376:62-66

23. Millaner B, Wixigman-Voos S, Schurch H, Martinez, Moller NPH, Risau W, Ulrich A. High affinicy VEGF binding and developmental expression suggests FLK-1 as a major regulator of vasculogenesis and argiogenesis. Coll 1993;72:835-846

24. Plate KH, Breier G, Weich HA, Mennel HD, Risau W. Vascular endothel lial growth factor and glioma angiogenesis: coordinare inducrion of VEGF receprors. Distribution of VEGF protein and possible in wivo regulatory mechanisms. Int / Cancer 1994;59:520-529

25. Chrocynski P. Sacchi N. Single-step method of RNA isolation by acid guanidinium thiocynatephenol-chloroform extraction. Anal Biochem 1987;162:156-159

26. Ku DD, Zaleski JK. Liu S, Brock TA. Vascular endothelial growth factor induces EDRF-dependent relaxarion in coronary arteries. Am J Physiol 1993;265:H586-H592

27. Wu HM, Huang Q, Yuan Y, Granger HJ. VEGF induces NO-dependent hyperpermeability in coronary venules. Am J Physiol 1996:271:H2735-H2739

28. Felctou M, Bonnandel $\mathrm{E}$, Canet E. Bradykinin and changes in microvascular permeability in the hamster cheek pouch: role of nitric oxide. Br J Pharmacol 1996:118:1371-1376 
29. Khan BV, Harrison DG, Obrych MT, Alexander RW, Medford RM. Nittic oxide regulates vascular cell adhesion molecule 1 gene expression and redox-sensirive cranseriprional events in humbn waseular endothel lial cells. Proc Naul Acad Sci USA 1996;93:9114-9119

30. Sramler JS, Singel DJ, Loscalzo J. Biochemistry of nitric oxide and its redox-activated forms. Sciente $1992 ; 258: 1898-1902$

31. Palmer RMI, Ashton DS, Moncada S. Vascular endothelial cells synthesize nirric oxide from L-arginine. Nature 1988;333:664-666.

32. De Vries C, Escobedo JA, Ueno H, Houck K, Ferrara N, Williams LT. The fns-like tyrosine kinase, a receptor for vascular endothelial growh factor. Science 1992;255:989 991

33. Senger DR, Connolly DT, Van de Water $L_{n}$ Feder $J_{*}$ Dworak HF. Purification and $\mathrm{NH}_{2}$-terminal amino acid sequence of guinea pig tumor-secreted vascular permeability factor. Cancer Res 1990;50:17741778

34. Gospodarowicz D, Abraham JA, Schilling J. Isolarion and characterization of a vascular endothelial cell mitogen produced by pituitary-derived folliculo stellate cells. Pror Nan Acad Sci USA 1989;86:7311. 7315

35. Jakeman LB, Armanini M, Phillips HS, Ferrara N. Developmental expression of binding sites and messenger ribonucleic acid for vascular endothelial growth facror suggests a role for this potein in vasculogenesis and angiogenesis. Endoctimology 1993;133:848-859

36. Breier G, Albrecht U, Sterrer $S$, Risau W. Expression of vascular endothelial growth factor during embryonic angiogenesis and endothelial cell differencation. Developwent 1992;114:521-532

37. Shweilki D, Irin A, Gicay-Goren H, Kesher E. Patterns of expression of vascular endorhelial growth factor (VEGF) and VEGF receptors in mice suggest a role in hormonally regulated angiogenesis. / Clin Invest 1993;91:2235-2243

38. Detmar M, Brown LF, Claffy KP, Yeo K-T, Kocher O, Jackman RW, Berse B, Dworak HF. Overexpression of vascular permeability factor (vascular endothelial growth factor) and its receptors in psoriasis. J Exp Med 1994;180:1141-1146

39. Brown LF, Berse B, Jackman RW, "Tognazzi K, Guidi AJ, Dvorak HE, Senger DR, Conolly JL, Schnirt S]. Expression of vascular endorhelial permeability factor (vascular endorluelial growth factor) and its receptors in breast cancev. Huwan Pathol 1995;26:86-91

40. Brogi E, Schatteman G, Wu T, Kim EA, Vartilkowski L, Keyt B, Isner JM. Hypoxia-induced paracrine regulation of wascular endothelial growth factor receptor expression. / Clin Invest 1996;97:469-476

41. LiJ, Brown LF, Hibberd MG, Grossman JD, Morgan JP, Simons M. VEGF, flk-l, and ft-1 expression in at rat myocardial infarction model of angiogenesis. Am / Physol 1996;270:H1803-H1811

42. Hashimoto E, Ogita T. Nakaoka T, Marsuoka R, Takao A. Kira Y, Rapid induction of vascular endothelial growth factor expression by ransient ischemia in tat heart. Am J Pbyol 1994;267:H1948H1954

43. Fuster $V_{n}$ Badimon $L$, Badimon J, Chesebro J. The parhogenesis of coronary artery disense and the acute cononary syndrome-11. New Engl J Med 1992;326:310-318

44. Asahara T, Bauters C, Pastore CI, Kearney M, Rossow S, Bunting S, Ferrara N. Symes JF, Isner JM. Local delivery of vascular endothelial growth factor accelerares reendothelialization and atrenuates intimal hyperplasia in balloon-injured rat carotid artery. Cinculation 1995:91:2793-2801 



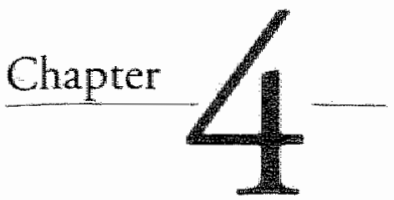

\section{Peroxynitrite Produced by}

Hypercholesterolemia-Induced Neointima Abrogates the Protective Action of Vascular Endothelial Growth Factor/Vascular Permeability Factor on Vascular Endothelium

Rien van der Zee, MD; Jonathan Passeri, BA; Dongfen Chen, MS; Marcy Silver BS; Jeffrey $M$. Isner, MD.

From the Departments of Biomedical Research and Medicine (Cardiology), St. Elizabeth's Medical Center, "Tufrs University, School of Medicine, Boston, Mass, 02135 . Rien wan der $Z$ ee is a recipient of a traveling grant of the Wynand N. Pon Foundation.

Submitted 


\section{Abstract}

Hypercholesterolemia is assaciated whith increased release of nitric oxide (NO) and intimal thickening. Vascular endothelial growth factortwascular permeability factor (VEGFVPF) also angments NO release, but bas been related to reduced intimal thickening.

To investigate this paradox, New Zealand white rabbits (NZWR) were fed a $1 \%$ cholesterol diet for either $6(N Z W R-6 w n=10)$ or 10 weeks (NZWR-10w, $n=10$ ). Agemathed Watanabe heritable byperlipidemic (WHHL) rabbits $(n=10)$ and contrals $(n=10)$ were kept on regular chow. At the end of the diet period, the artat was removed for direct $N O$ measurement, contractionirelaxation experiments, bistology (Oil Red $O$, HeE), and immunohistochemistry ("-NOS, eC-NOS, RAMII, nitrotyrosine).

In the control group no changes were registered. In the NZWR-6w group. (a) intiwnal bickening was absert, (b) a 2-fold rise in NO release was produced exlusively wia ec-NOS, and (c) VEGF/VPF induced a further increase in functional NO. In the NZWR-10w and the WHHL group, (a) intimal Wickening with abundaw influation of macrophages/foam cells bad occurred. (b) a IO-fold rise in NO release was produced mainly uia i-NOS expressed in intimal cells, (c) peroxynitrite ( $\mathrm{ONOO}^{-}$), produced by the reaction of NO with the superaxide anion $\mathrm{O}_{2}-$, was evidenced by demonstrating deposition of nitrotyrosine in the neointima, and (d) VEGF/VPF was not capable in restoning the reduced bioavailability of $\mathrm{NO}$.

In conclusion, VEGF/VPF augments functional NO release by endothelial cells. In bypercholesterolemia the formation of peroxynitrite is associated with reduction of the bioawailability of endothelial $\mathrm{NO}$. 
Vascular endothelial growth factor/vascular permeability factor (VEGF/VPF) has a putative function in quiescent adult rabbir endothelium and in human coronary bypass grafts by regulating constitutive endothelial cell nitric oxide (NO) release. ${ }^{1.2 .3}$ In addicion. VEGFNPF has a role in repair of endothelium-dependent function in two different models of arterial injury, reducing intimal thickening. 4,5 The function of VEGF/VPF in the developing primary lesion in a hypercholesterolemic environment has not been reported on.

Previously, it was documented that high cholesterol dier-induced atherosclerosis augments the release of nitrogen oxides in the rabbit aorta. ${ }^{6.7}$ However", the precise mechanism responsible for this observation is still unclear. In the present study, we sought to determine the extent to which VEGF/VPF stimulates the release of NO in the arterial wall that has been exposed to hypercholesterolemia.

Normally, NO release is mediated by the endothelial cell constitutive nicric oxide synthase (ecNOS)/calmodulin complex. $8,9,10$ In this study evidence is provided that $\mathrm{NO}$ production is increased by 2 -fold in aortic rings of 6 weeks cholesterol-fed rabbits. At this point, the aortic rings still have a normal histological appearance. VEGFNPF is capable of inducing a further increase in NO production, implicating preservation of functional VEGF-receptors. Furthermore, administration of VEGF/VPF did cause vasorelaxation in aortic rings as opposed to acerylcholine ( $\mathrm{ACl}$ ), which typically fails to induce vasorelaxation in a hypercholesteremic vessel. ${ }^{11,12}$ Interestingly, both VEGF/VPF and ACh caused increased NO production, but only VEGF/VPF had a functional effect on change in vascular tone.

After 10 weeks of cholesterol feeding neointimal thickening had occurred. A 10-fold increase in baseline $\mathrm{NO}$ production was registered in these type of vessel rings. VEGF/VPF still angmented NO release, but now failed to cause vasorelaxation. We hypothesized that a simultaneous increase in $\mathrm{NO}$ production and excess generation of a superoxide anion $\left(\mathrm{O}_{2}^{-}\right)$in the neointima of hypercholesterolemic vessels results in the formation of peroxynitrite ( $\mathrm{ONOO}{ }^{-}$). As $\mathrm{NO}$ is captured in the generation of this potent oxidizing molecule, the regularing function of the endothelium on vascular processes, such as mediating vasorelaxation, is lost. Furthermore, the increase in oxidative stress is a powerful stimulus for iniriation and development of atherosclerosis. Therefore, it can be hypothesized that VEGF/VPF preserves endothelial function in hypercholesterolemia, until structural remodeling occurs involving the generation of highly reactive nitrogen oxide radicals. 


\section{Methods}

\section{Drugs, chemicals, and antibodies}

Heterodimeric recombinant human VEGF/VPF, purified from E. Coli, was a gift of Napoleon Ferrara and Stuart Bunting, Genentech, South San Fransisco, CA. 3-Amino9-ethylcarbazole (AEC) and 3,3" diaminobenzidine (DAB) was purchased from Biogenex (San Ramon, CA). ACh, $N^{G}$-monomethyl-L-arginine (L-NMMA), MOPC-21, and other chemicals were obtained from Sigma Chemical (St. Louis, MO). Krebs solurion and Griess reagent were prepared daily. Stock solurions of VEGF/VPF, dissolved in a phosphate-buffered solution (PBS), and $\mathrm{ACh}$, dissolved in sodium acetate buffer ( $\mathrm{pH}$ 4.0) were refrigerated until they were used. Pellets of L-NMMA were added to the organ bath solution at established concentrations of $0.2 \mathrm{M}$.

The antibodies used for immunohistochemistry were monoclonal mouse antinitrotyrosine (Upstate Biotechnology, Lake Placid NY), monoclonal mouse anti-iNOS and ec-NOS (Transduction Laboratories, Lexington, KY), mouse anti-rabbit macrophage 11 (RAM 11; Dako, Carpinteria, CA), and a monoclonal goar-anti-human VEGF ${ }_{165} /$ VPF (R\&D System, Minneapolis, MN). Secondary antibodies were included in the Streptavidin Level 2 Kit (Signet, Dedham, MA). All used antibodies have been shown to be specific for the tested receptors.

\section{Cholesteral feeding}

Experiments were performed on the thoracic aorta isolated either from New Zealand white rabbits (NZW) rabbits or from age-matched Watanabe heritable hyperlipidemic (WHHL) rabbits. Only male rabbits were used to avoid variations in outcome artributable to gender alone. The experimental protocol described was conducted according to protocols approved by the St. Elizabeth's Institutional Animal Care and Use Committee. Hypercholesterolemia was induced in NZW rabbits by feeding a $1 \%$ cholesterol diet for 6 weeks $(n=10)$ or for 10 weeks $(n=10)$. Age-matched controls $(n=10)$ and WHHL rabbits were maintained on standard rabbit chow.

\section{Vessel preparation}

Harvesting and preparing the thoracic aorta was conducted as described previously. ${ }^{1}$ In short, the rabbits were killed by exsanguination. Blood was collected from all rabbits to determine total cholesterol with an automatic analyzer (Kodak 700, Johnson and Johnson, Rochester, NY). Immediately after cessation of respiration, the thorax was opened and the aorta was excised from aortic valve to the diaphragmatic hiatus. Connecrive and other adhesive rissue was removed and the vessels were washed initially in PBS. Then, the aorta was subdivided; the proximal part ( $n=6 /$ group) was used for morphologic studies. Half of it was dehydrated in a graded series of ethanol and parrafin 
embedded, the remaining part was embedded in OCT compound (Miles Inc, Elkhart, $\mathbb{I N}$ ), frozen in liquid nitrogen, and stored at $-70^{\circ} \mathrm{C}$ until further analysis. For Western blorting the entire proximal part of the aorta was frozen ( $n=4 /$ group).

The adjacent part of the aorta was placed in Krebs buffer $(118 \mathrm{mM} \mathrm{NaCl}, 4.6 \mathrm{mM}$ $\mathrm{KCl}, 27.2 \mathrm{mM} \mathrm{NaHCO}_{3}, 1.2 \mathrm{mM} \mathrm{MgSO}_{4}, 2.5 \mathrm{mM} \mathrm{CaCl}_{2}, 1.2 \mathrm{mM} \mathrm{KH}_{2} \mathrm{PO}_{4}$, and 11.1 $\mathrm{mM}$ glucose, $\mathrm{pH} 7.4$ ), aerated with a $95 \% \mathrm{O}_{2}-5 \% \mathrm{CO}_{2}$ gas mixture, and maintained at a constant temperature of $37^{\circ} \mathrm{C}$. This part of the aorta was cur at $5 \mathrm{~mm}$ inrervals to ensure optimal exposure of the endothelium to oxygen and reagents added to the organ chamber. For some experiments, the endothelium was mechanically removed by rubbing the interior of the vessel rings with a wetted cotton swab.

\section{Measurement of $N O$}

Fifteen minutes before administration of the reagents $(t=-15)$ the fluid in the organ chamber was replaced to remove any remaining hemoglobin. The reagents were administered at $\mathrm{r}=0 \mathrm{~min}$ in a concentrated fashion to avoid significant dilution of the $\mathrm{NO}$ or nitrite $\left(\mathrm{NO}_{2}^{-}\right)$concentration in the organ bath solution. PBS was added for control experiments.

NO was determined at different points in time before and after administration of the reagents to be tested. ${ }^{1}$ For each cimepoint a $0.7 \mathrm{ml}$ alliquot was sampled from the organ bath solution and added to a $1 \mathrm{ml}$ cuvette with an optical path of $1 \mathrm{~cm}$, prefilled with $0.07 \mathrm{ml}$ of Griess solution (1\% sulfanilic acid, $0.1 \%$ naphthalene-ethylene diamine in $5 \% \mathrm{H}_{3} \mathrm{PO}_{4}$ ). Naphthalene-ethylene diamine reacts with nirrogen oxides, the product renders the solution in the cuvette pink. This color displays a spectrophotometric peak at $548 \mathrm{~nm}$. The absorbance at $548 \mathrm{~nm}$ was determined with a diode array photospectrometer (8452A, Hewlet Packard, Andover, MA) and was translated into NO concentration using a standard curve which, in our experience, was linear from 0.03125 $\mu \mathrm{M}$ to $0.25 \mu \mathrm{M} \mathrm{NO}_{2}{ }^{-}$. As a blank, Krebs solution, which had not been exposed to the vascular segments, mixed with Griess solution in a similar fashion, was used.

\section{Contraction/relaxation experiments}

The $5 \mathrm{~mm}$ aortic rings were mounted using two L-shaped 30-gauge srainless steel hooks, one of which was immobile and the other connected by a silk surure to a force displacement transducers (model 7D polygraph, Grass instrument Company, Quincy, MA) for recording isomerric tension development. The assay was performed with rings placed in Krebs buffer as described above. Vessels were passively stretched to $2.0 \mathrm{~g}$ for isometric force. After $45 \mathrm{~min}$ of equilibration, the aortic rings were exposed to $70 \mathrm{mM}$ $\mathrm{KCl}$-solution to assess maximal depolarization. When the contractile response reached a plateau fase, the solution in the organ chamber was replaced by fresh Krebs buffer and again was allowed to equilibrate for $45 \mathrm{~min}$ in the presence of $5 \mu \mathrm{M}$ indomethacin for complete inhibition of cyclooxygenase and subsequent production of vasoactive 
prostanoids. The effect of VEGF/VPF or ACh was determined after evoking submaximal tone, defined as approximately $30-50 \%$ of the maximal inducible rone caused by $\mathrm{KCl}$, with norepinephrin (NOR) before the cumularive addirion of either VEGFIVPF or ACh into the organ barh solution. Data are expressed as percentage of change in NOR-induced vascular rone.

\section{Histology/immunohistochemistry}

The part of the aorta that was embedded in parrafin was stained with hematoxylin and eosin and used for immunohistochemistry to show the presence of RAM 11. All other immunohistochemical staining and the Oil Red $O$ reaction for fat were performed on 6 Min frozen sections.

Tissue was fixed and permabilized at $-20{ }^{\circ} \mathrm{C}$ for $5 \mathrm{~min}$ in $100 \%$ methanol. Endogenous peroxidase activity was blocked with $3 \% \mathrm{H}_{2} \mathrm{O}_{2}$ for $5 \mathrm{~min}$, and tissue was reated with normal horse serum to prevent non-specific binding of biorinylated horse anti-mouse immunoglobulins, which were applied as secondary antibody. Then, the slides were incubated with mouse anti-RAM 11 (owernight at $4^{\circ} \mathrm{C}$, diluted $1: 400$ in $1 \%$ bovine serum albumine (BSA)/PBS), mouse anti-nitrotyrosine ( 1 hour at $37^{\circ} \mathrm{C}$, diluted $1: 100 \mathrm{in} \mathrm{1 \%}$ BSA/PBS), and mouse anti-inducible nitric oxide synthase (anti-iNOS) or endothelial cell constitutive nitric oxide synthase (ecNOS; overnight at $4^{\circ} \mathrm{C}$, dilluted $1: 25$ in $1 \%$ BSA/PBS). For negative controls equal amounts of non-specific mouse anti-rabbit $\operatorname{IgG}_{1}$ (MOPC-21) were applied. After administration of the secondary anribody and streptavidin-horseradish peroxidase, the slides were incubated with AEC (ecNOS, iNOS, nitrotyrosine) causing a red color or DAB (RAM 11) causing a brown color. The tissue was counterstained with hematoxylin and coverslipped with glycerol gelatin mouncing medium.

\section{Western blot}

The aortas were cur into small pieces and treated wirh lysis buffer containing protease inhibitors (PMSF, Pepstatin A, Aprotinin, and Leupeptin). The tissue was homogenized and centrifuged for $20 \mathrm{~min}$ at $15,000 \mathrm{~g}$ at $4{ }^{\circ} \mathrm{C}$, boiled, and centrifuged again. Protein concentrations were calculated using BSA as a standard. After loading of equal amounts per lane, the proteins were separated by gel-electrophoresis and transferred to $0.2 \mu \mathrm{M}$ PVDF-membranes (Bio-Rad Laboratories, Hercules, CA) in $25 \mathrm{mM}$ Tris, $200 \mathrm{mM}$ glycine, $1.3 \mathrm{mM} \mathrm{SDS}$, and $20 \%$ methanol at $30 \mathrm{~mA}$ for 3 hours. Non-specific protein binding sites were blocked with $10 \%$ dry milk for 1 hour. The protein was overlaid with purified goat anti-human VEGF $165 / \mathrm{VPF}$, diluted $1 \mu \mathrm{g} / \mathrm{ml}$. For a negative control non-immune goat $\operatorname{Ig} \mathrm{G}_{1}$ was used. Then, biotinylated horse anti-goat immunoglobulin was applied, followed by incubation with streptavidin-horseradish peroxidase. Images were obtained on X-ray film using the ECL kit (Amersham Life Science, Arlington Heights, IL). 


\section{Calculations/statistical analysis}

The increase in NO caused by the sample-induced decrease in volume of the organ chamber in the presence of a NO-producing source was corrected for according to the formula:

$C_{t}=C_{x-2}+\left(C_{t}-C_{x-2}\right) \cdot\left(\left(V-\pi \cdot V_{s}\right) / V\right)$,

in which $C_{r}$ is the NO concentration ar times $=\mathrm{min} ; \mathrm{x}=15 \mathrm{~min} ; \mathrm{V}$ is the initial volume in the organ chamber $($ i.e. $10 \mathrm{ml}) ; \pi$ is the number of sampling times; and $V_{\mathrm{s}}$ is the sampling volume (i.e. $0.7 \mathrm{ml}$ ). To correct for differences in size of vascular segments, the NO production was standardized for surface area (SA). The $[N O]$ per $S A$ in $\mu \mathrm{M} / \mathrm{m}^{2}$ was documented, assuming that the production of $\mathrm{NO}$ was equal across the entire endothelium.

Values are given as means \pm standard error $(M \pm S E M)$. If $n=2$, bars indicate the range of obtained values. The data were evaluated using a 2-factorial (significance over time, significance of drug effecr) analysis of variance (ANOVA) for repeated measurements. For comparison of paired values the two-tailed Student t-test was applied. Statistical significance was inferred when $p<0.05$.

\section{Results}

\section{Cholesterol levels}

The total serum cholesterol concentrations in the cholesterol-fed NZW and the WIHHL rabbits were significantly elevared compared to the rabbits assigned to regular chow (Figure 1). Note the exponential increase in cholesterol levels occurring after 6 weeks of $1 \%$ cholesterol feeding.

\section{Measurement of NO}

$\mathrm{ACh}$ administered to the organ barh solution at $\mathrm{t}=0 \mathrm{~min}$ induced an immediate increase in NO release by the aortic rings harvested from regular chow-fed rabbits as opposed to the vascular segments of the 6 weeks cholesterol-fed rabbits where ACh generated higher NO levels only after $9 \mathrm{~min}$ (Figure 2). Although NO started to increase almost immediate after $\mathrm{ACh}$ administration, more time elapsed to register significant differences because baseline NO release was already elevared by 2 -foll.

When VEGF/VPF was administered, NO production was also augmented, but the onset of the increase was slower compared to $\mathrm{ACh}$ (Figure 3). Binding of the reagents to different types of receptors, as described previously ${ }^{\natural}$, is a possible explanation of the temporal differences. Removal of $\mathrm{CaCl}_{2}$ from the Krebs solution abrogated the stimulatory effect of VEGF/VPF, resulting in a NO production that did not differ 


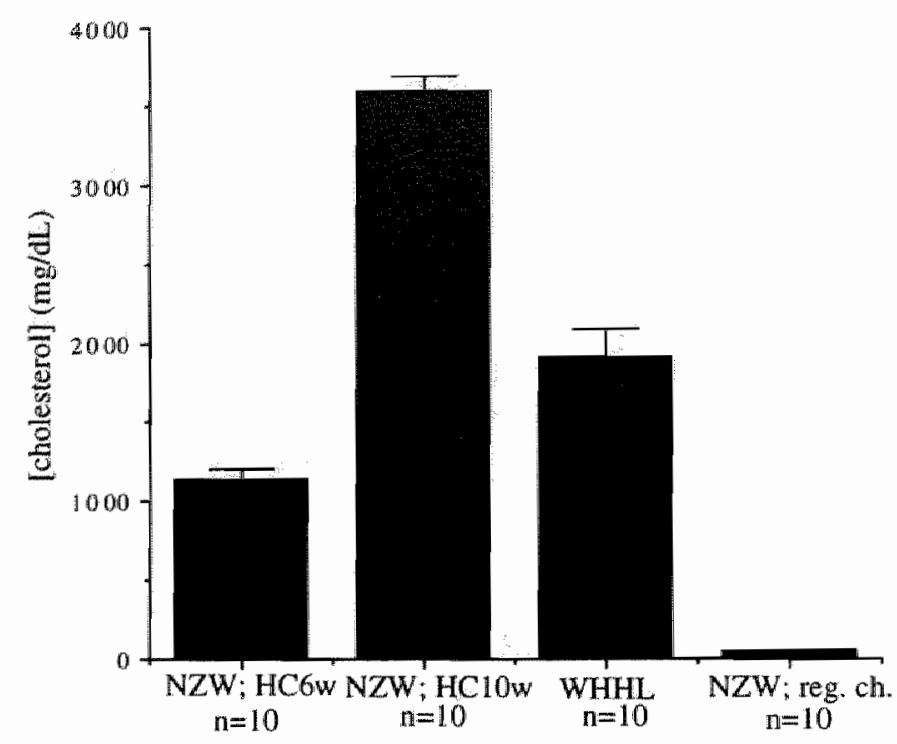

Figure 1. Total serum cholesterol concentrations in New Zealand white rabbits and Watanabe Rabbits. HC 1\%: high cholesterol diet; NZW: New Zealand white rabbit; reg. ch.: regular chow; w: weeks; WHHL: Waranabe heritable hyperlipidemic rabbit.

significantly from baseline conditions or from unstimulated aortic rings (Figure 4). This observation provides inferential evidence for the involvement of calcium-sensirive ecNOS in the generation of the increased constiturive release of $\mathrm{NO}$ in the aortic rings after 6 weeks of cholesterol feeding. Similar results were registered following mechanical removal of the endothelium. Co-administration of $0.2 \mathrm{M} \mathrm{L-NMMA}$ ar time $t=0 \mathrm{~min}$ also prevented any rise in NO production after stimulation with VEGF/VPF. Moreover, incubating with L-NMMA produced a tendency to diminish NO producrion, compared to the values obtained for the unstimulated aortic rings.

The baseline production of aortic rings after 10 weeks of a high cholesterol diet is increased by approximately 10-fold compared to the producrion of vascular segments obtained from rabbirs feeding on regular chow (Figure 5). Administration of ACh did not cause an increase in NO production (data not shown). Most likely, the elevated baseline production of $\mathrm{NO}$ masks a stimulatory effect of $\mathrm{ACh}$, although it cannor be ruled out that the muscarinic $G$-protein coupled receptors properties are affected in a rabbit model of hypercholesterolemia. 13,14,15,16 VEGF/VPF, however, induces a significant rise in NO production at $\mathrm{t}=8 \mathrm{~min}$, which is typically the point in time at which $\mathrm{NO}$ release displays a maximum value.' The decrease in NO production after $8 \mathrm{~min}$ has been thought to be the result of the short half-life time of VEGFNPF in vivo (Napolcon Ferrara, 


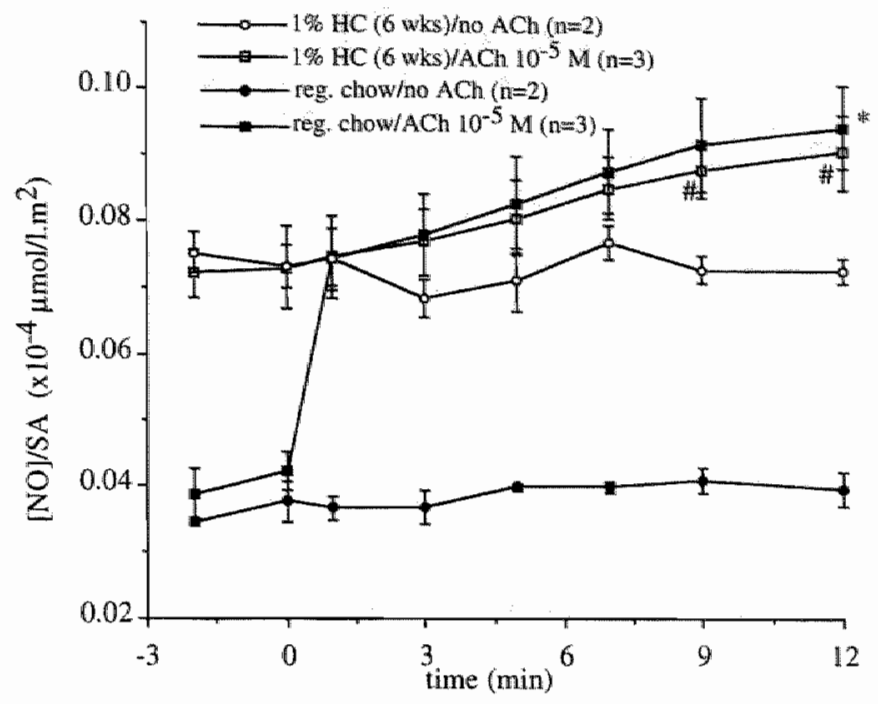

Figure 2. NO production in response to acetylcholine administration. ACh: acerylcholine; $\mathrm{HC}$ : high cholesterol diet; reg.: regular; SA: surface area: ": $\mathrm{p}<0.05$ for increase in time* \#: $p<0.05$ for drug effect at $t=9$ and $t=12 \mathrm{~min}$.

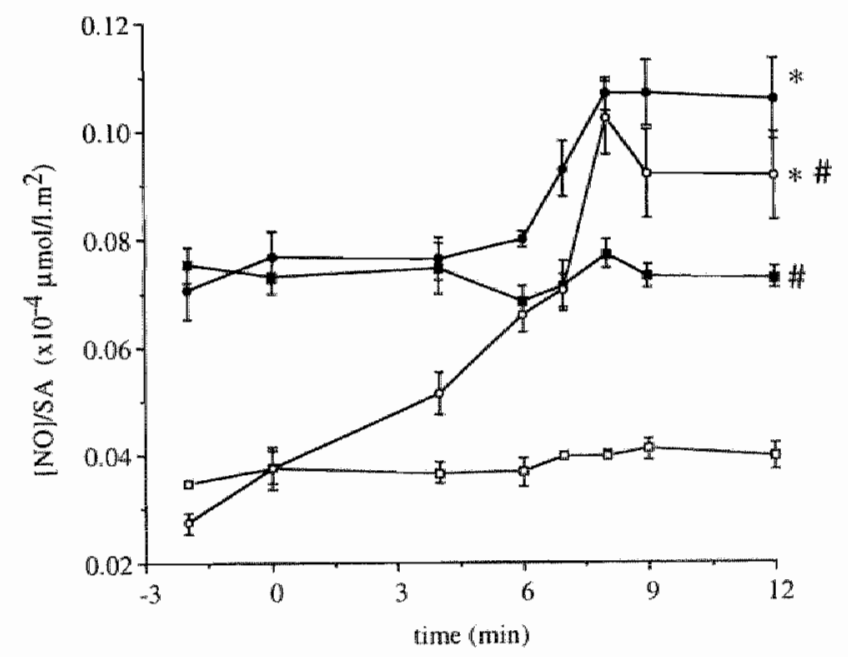

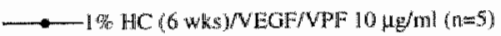

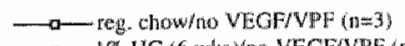
- regen Chow $/$ EGF/NPF $10 \mu \mathrm{g} / \mathrm{m} /(\mathrm{n}=4)$

$\longrightarrow-1 \% \mathrm{HC}$ (6 whs yno VEGF/MPFi in=

Figure 3. NO production by aortic rings in response to VEGF/VPF administration after 6 wectks of cholesterol feeding. HC: high cholesterol diet; SA: surface areat VEGFNPF: vascular endothelial growth facror/vascular permeability factor; ": $\mathrm{p}<0.05$ for increase in cime; \#: $\mathrm{p}<0.05$ versus 'regular chow/no VEGF/VPF', 


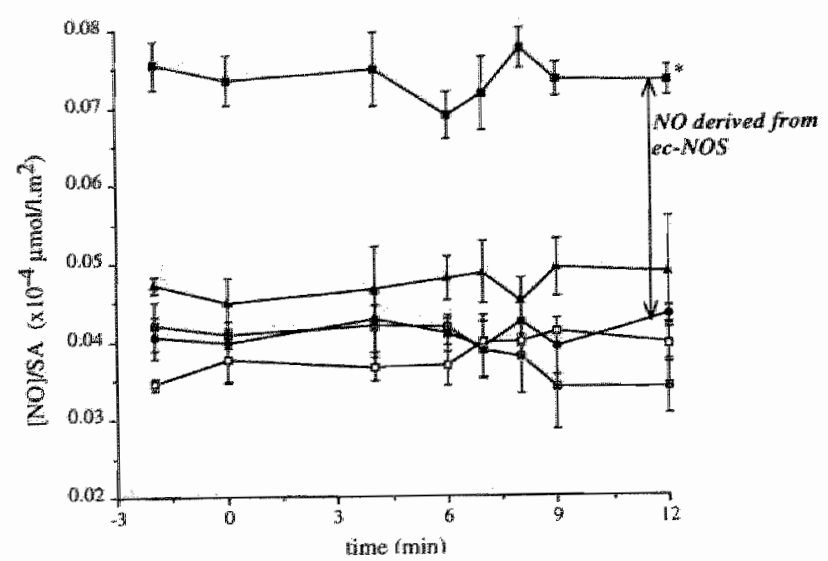

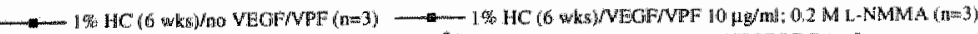

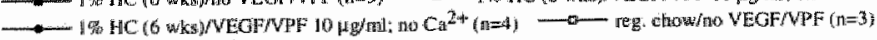

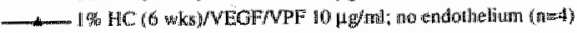

Figure 4. NO production by aortic rings in response to VEGF/VPF administration after 6 weeks of cholesterol feeding without $\mathrm{Ca}^{2+}$, vascular endothelium, or with L-NMMA ccNOS: endothelial cell constiturive nitric oxide synthase; $\mathrm{HC}$ : high cholesterol diet; L-NMMA: $\mathrm{N}^{\mathrm{G}}$-monomethyl-L-arginine; $S A$ : surface area; VEGF/VPF: vascular endothelial growth factor/vascular permeability facton; * pe0 0.05 versus 'regular chow; no VEGFNPF", "1\% HC (6 wks); VEGE/VPF 10 $\mu \mathrm{g} / \mathrm{ml}$; no endothelium", ' $1 \%$ HC (6 wks); VEGF/VPF $1.0 \mu \mathrm{g} / \mathrm{ml}$; no Cad ${ }^{2+c}$, and " $1 \% \mathrm{HC}$ (6 wks); VEGF/VPF $10 \mu \mathrm{g}^{\prime} \mathrm{ml}: 0.2 \mathrm{M} \mathrm{L-NMMA}$.

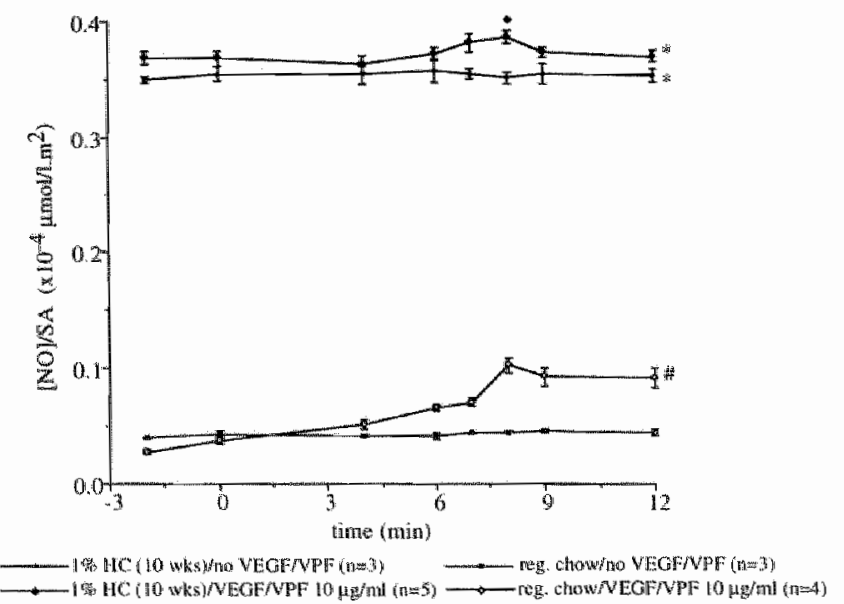

Figure 5. NO production by antic rings in response ro VEGF/VPF administration after 10 weeks of cholesterol feeding. HC. high cholesterol dier; SA; surface area; VEGFVPF: vascular endothelial growth factor/vascular permeability factor; *: $p<0.05$ versus regular chow; $p<0.05$ for increase in time; $\quad p<0.05$ versus " $1 \%$ HC (10 wks); no VEGF/VPF" at $8 \mathrm{~min}$. 
personal communication). Inferentially, this maximun value at $8 \mathrm{~min}$ suggests the preservation of functional VEGF/VPF receptors in a hypercholesterolemic milieu. As opposed to the observed decrease in $\mathrm{NO}$ production when $\mathrm{CaCl}_{2}$ was removed from the organ bath solution containing the aortic rings harvested from rabbits after 6 weeks of cholesterol feeding, the aortic segments of 10 weeks cholesterol-fed rabbits displayed an unaltered $\mathrm{NO}$ release when exposed to the same conditions (Figure 6). This observation points to the fact that the produced NO is produced by calcium-insensitive iNOS. Removal of $\mathrm{CaCl}_{2}$ did abolish the stimulatory effect of VEGF/VPF, which apparently involves ecNOS, but not i-NOS. Mechanical disruption of the endothelium with a wetred cotton swab also failed to significantly diminish $\mathrm{NO}$ release, which is in accordance with iNOS, rather than ecNOS, as the involved enzyme in producing $\mathrm{NO}$. Co-administration of L-NMMA reduced NO release by approximately $50 \%$ and completely abrogated the stimulatory effect of VEGF/VPF.

The documented increase in baseline NO production in aortic rings of NZW rabbits 10 weeks after a high cholesterol diet was confirmed in vascular segments harvested from the WHHL rabbits, although averaged serum cholesterol concentration was only half the

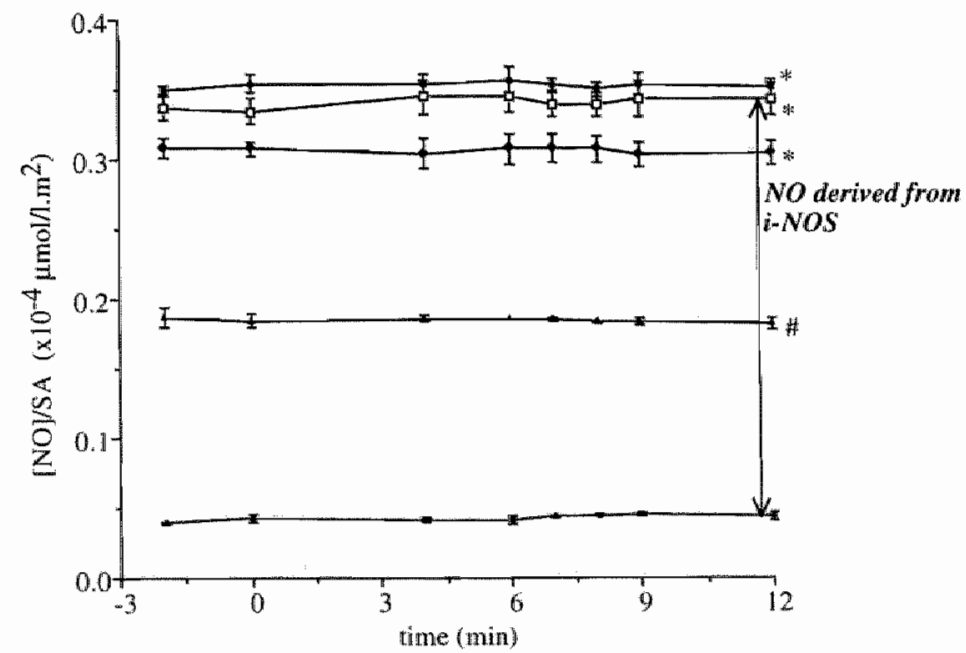

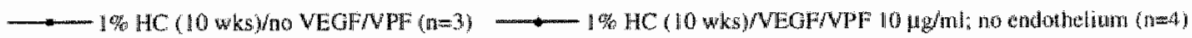

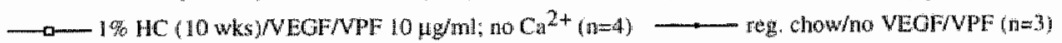

$1 \% \mathrm{HC}(10 \mathrm{wg}) / \mathrm{VEGF} / \mathrm{VPF} 10 \mathrm{\mu g} / \mathrm{mm} ; 0.2 \mathrm{ML}$ LNMMA $(\mathrm{n}=3)$

Figure 6. NO production by aorric rings in response to VEGF/NPF administration afrer 10 weeks of cholesterol foeding without $\mathrm{Ca}^{2 *}$, vascular endothelim, or with L-NMMA. HC: high cholesterol diet: iNOS: inducible nitric oxide synthase, L-NMMA. NG-monomethyl-Larginine; SA: sutface area; VEGE/VPF: vascular endothelial growth Gocor/vascular permeabilicy factor; : pe0 05 versus "regular chow' and "1\% HC (10 whs); VEGFNPF $10 \mu \mathrm{g} / \mathrm{m}$; $0.2 \mathrm{M}$ L-NMMA; \#: p<0.05 versus " $1 \% \mathrm{HC}(10 \mathrm{wks})$; no VEGF/VPF", "1\% $\% \mathrm{HC}$ (10 w/s); VEGF/VPF" $10 \mu \mathrm{g} / \mathrm{ml}$, no endothelium", and $" 1 \% \mathrm{HC}(10 \mathrm{wks}) ; \mathrm{VEGE} / \mathrm{VPF} 10 \mu \mathrm{g} / \mathrm{ml}$ no $\mathrm{Ca}{ }^{2+}$. 


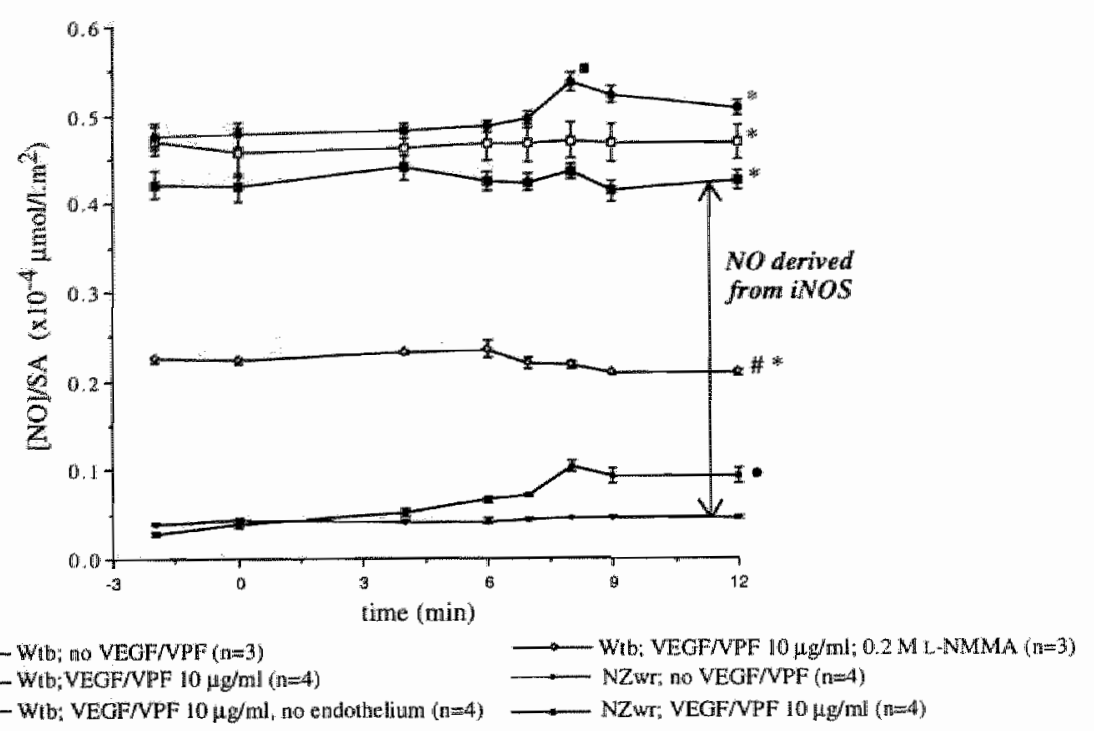

Figure 7. NO production by artic rings from WHHL rabbits in response to VEGF/VPF administration. HC: high cholesterol diet; iNOS: inducible nicric oxide synthase: L-NMMA: NG-monomethyl-L-arginine; NZwr: New Zealand white rabbits; SA: surface area; VEGF/VPF: vascular endorheliall growth factorivascular permability factor; Wtb: Watanabe heritable hyperlipidemic rabbits; * $\mathrm{p}<0.05$ wersus $N Z$ Wr; $* \mathrm{p}<0.05$ versus $\mathrm{NZwr}$ and $\mathrm{W}$ tb; no VEGF/VPF'; 0 : 0.05 for increase in time; $\mathrm{p}<0.05$ versus 'W'tb; no VEGF/VPF" at $\mathrm{t}=8 \mathrm{~min}$.

value obtained from diet-induced hypercholesterolemic rabbits (Figure 7). Structural remodeling rather than cholesterol concentration per se might be responsible for the observed differences in quantity and source of NO production.

\section{Contraction/relaxation experiments}

Figure 8 shows typical tracings of the effects of cumulative administration of VEGF/VPF and $\mathrm{ACh}$ on isolated aorric rings harvested from NZW rabbits after 6 weeks of a high cholesterol diet. Norepinephrin was used to induce the initial contractile tone. VEGF/VPF produced a slowly developing relaxation, reversible with L-NMMA, whereas ACh failed to induce a relaxing effecr. However, administration of sodium nitroprusside (SNP) resulted in immediate relaxation, demonstrating that aorric rings of hypercholesterolemic rabbits can dilate in response to $\mathrm{NO}$.

Figure 9 demonstrates the significant difference in vasorelaxation as a result of $\mathrm{ACh}$ administration in hypercholesterolemic and regular chow-fed rabbits. In figure 10 VEGF/VPF-induced vasorelaxarion is summarized. Note that after 10 weeks of high cholesterol feeding the aortic rings do not dilate anymore after stimulation with VEGF/VPF as opposed to the vascular segments harvested from rabbits who have been 


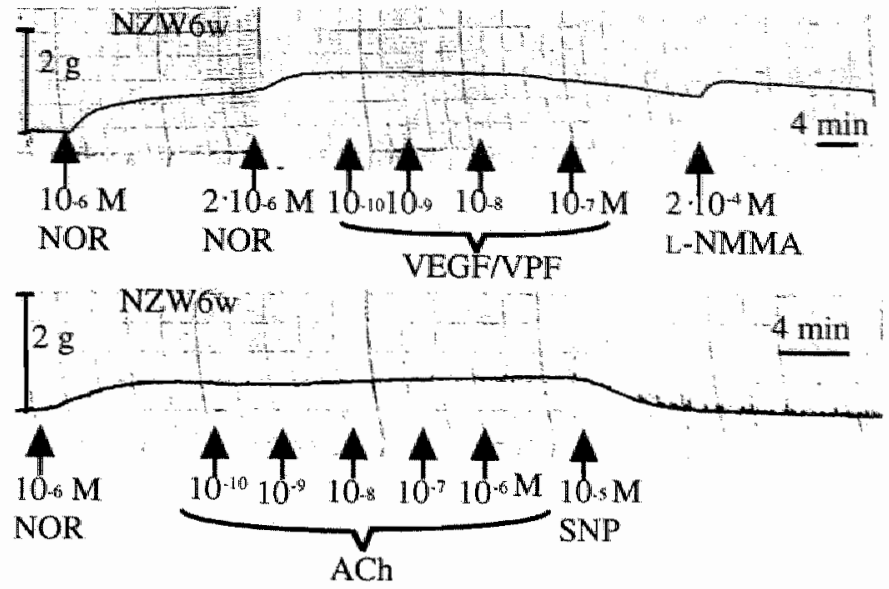

Figure 8. Tracings from contraction/relaxation experiments with aortic rings of NZW after 6 weeks of high cholesterol feeding.

A: Administration of VEGF/VPF. The intial force was induced with a double dose of NOR to reach approximately $50 \%$ of the maximal depolarizarion.

$B$ : Administration of $A C h$ did nor cause a relaxing effect in aortic rings that had been exposed to hypercholesterolemia. ACh: acecylcholine; L-NMMA: $\mathrm{N}^{\mathrm{G}}$-monomerhyl-L-arginine; NOR: norepineplurin; NZW; New Zealand white rabbits; SNP: sodium nitroprusside; VEGF/VPF: vascula endothellial growth factor/vascular permeabiliry factor; w: weeks of a $1 \%$ cholesterol diet.

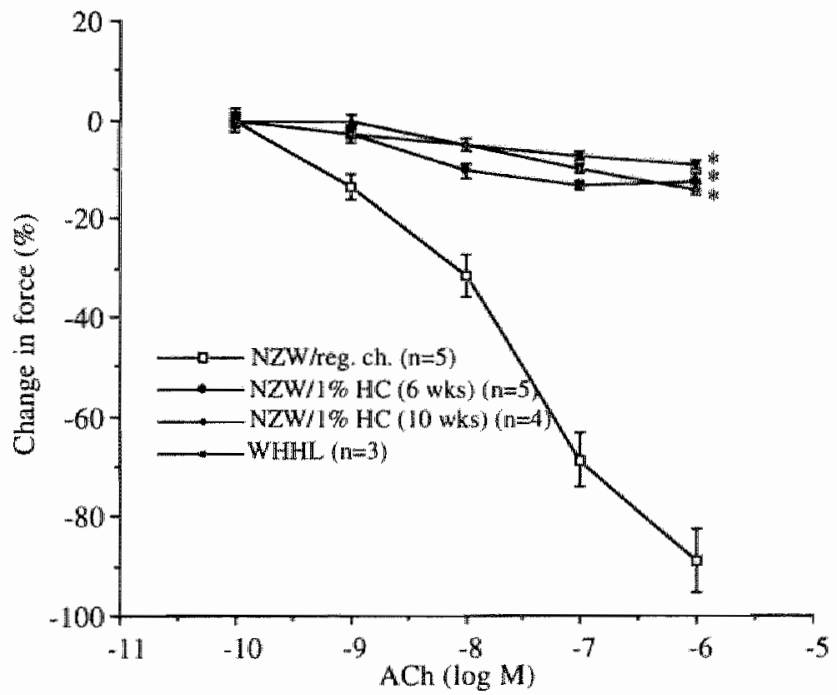

Figure 9. NO-dependent relaxation in aoric rings after administration of $A C h$. ACh: acerylcholine; $\mathrm{HC}$, high cholesterol diet; $\mathrm{NZW}$ : New Zealand white rabbit; reg. ch.: regular chow: WHHL: Waranabe heritable hyperlipidemic rabbit; ": p< 0.05 versus "NZW/reg. ch." 


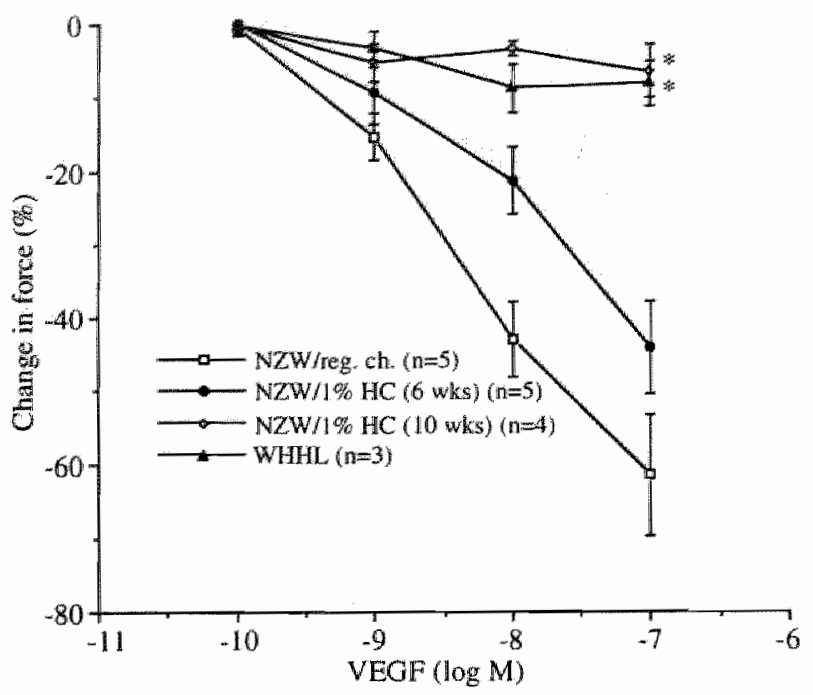

Figure 10. NO-dependent relaxation in aortic rings after administration of VEGF/VPF.

HC: high cholesterol dien; NZW: New Zealand white rabbit; reg, ch.: regular chow; VEGF/NF: vascular endothelial growth factor/vascular permeability factor; WHHL: Watanabe heritable hyperlipidemic rabbir; ": $p<0.05$ versus ' $N Z W$ reg. ch." and 'NZW $1 \%$ HC (6 whs)."

fed a high cholesterol diet for only 6 weeks. The aortic rings obtained from WHHL rabbirs behaved similar to the rings of the 10 weeks cholesterol-fed rabbits.

\section{Histology/immunobistochemistry}

The data obtained from measuring $\mathrm{NO}$ were confirmed with immunohistochemistry. Evidence is presented that ecNOS expression, but not iNOS, is present after 6 weeks of cholesterol feeding. Note that the ecNOS appearance includes the cytosol rather than the membrane of endorhelial cells (Figure 12). Afrer 10 weeks, when neointimal thickening has emerged, iNOS becomes expressed predominantly throughout the neo-intima. The cells in the neointima are mainly macrophages/foam cells (Figure 13). The deposition of nitrocyrosine, a marker for peroxynitrite generation, is also observed in the basale layers of the neointima. (Figure 14) Note that iNOS expression and deposition of nitrotyrosine correlate as well. 

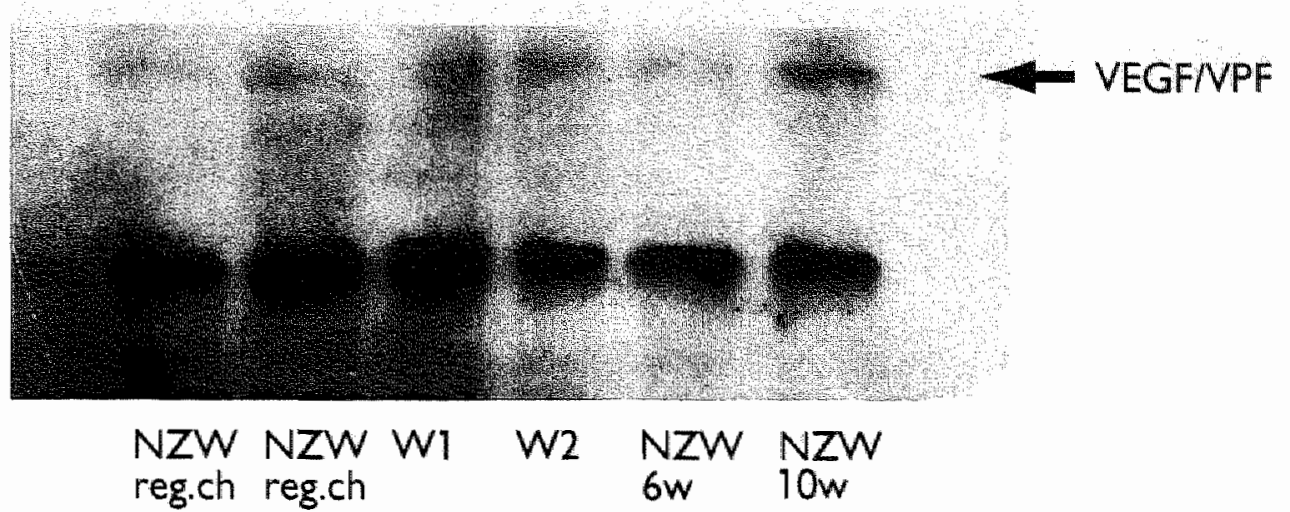

Figure 15. Expression of VEGF/VPE protein in the thoracic aorta of hypercholesterolemic rabbits. VEGF/VPF is withour significant differences expressed in all groups $(n=4 /$ group $)$. NZW: New Zealand white rabbit; VEGF/VPF: vascular endothelial growh factor/vascular permeability factor; wa weeks of a $1 \%$ cholesterol dier; W: Watanabe heritable hyperlipidemic rabbit.

\section{Western blot}

Previously, several groups postulated that VEGF/VPF had chemotactic properties culminating in infiltration of monocytes into the vessel wall. ${ }^{17.18 .19}$ "To test the theory that increased baseline NO production by vascular endothelial cells is related with upregulated VEGF/VPF expression in the vascular wall, the quantity of the VEGF/VPE protein was documented in the vessels of hypercholesterolemic and regular chow-fed rabbits. VEGF/VPF appeared to be expressed in all groups without significant differences. The tendency of a slighty elevared expression in the aorta of $\mathrm{New} Z$ Zealand white rabbits that have been fed a $1 \%$ cholesterol dier for 10 weeks appeared not to be a consistent finding (Figure 15). From this experiment, it can be conduded that the elevated baseline NO production is not the result of increased VEGF/VPF expression throughout the vessel wall. In addition, the similar expression of VEGF/VPF in all groups does not support the hypothesis that the infiltration of macrophages/foam cells is mediated by VEGF/VPF. 


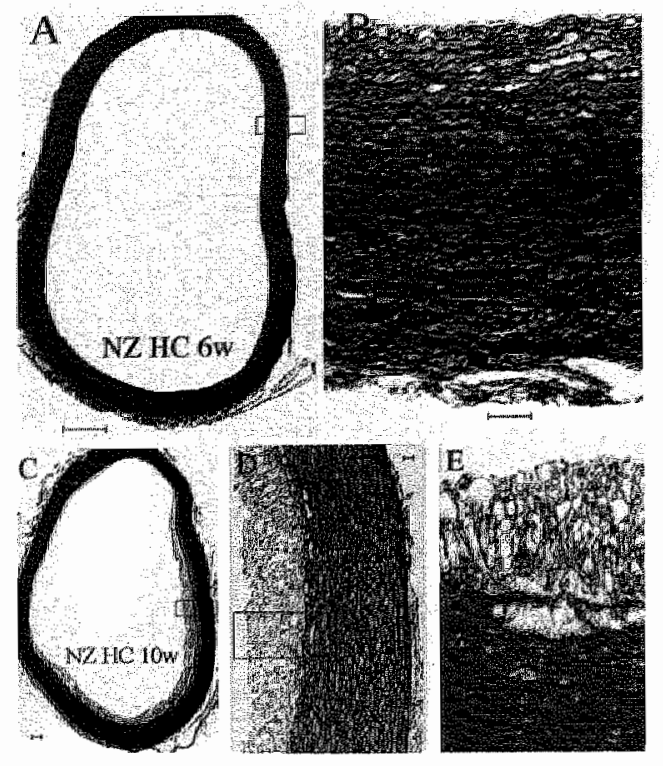

Figure 11. Structural remodeling in hypercholesterolemic rabbits. A-D: Masson trichrome stained sections. E: stained with hematoxylin and cosin. Nore that no visible changes have occurred after a 6 week cholesterol diet as opposed to the apparent incimal thickening in $\mathbb{N Z}$ after 10 weeks of cholesterol feeding or in WHHL. The scale bar represents $50 \mu \mathrm{m}$. HC: high cholesterol dier; NZ. New Zealand white rabbit; w: weeks.

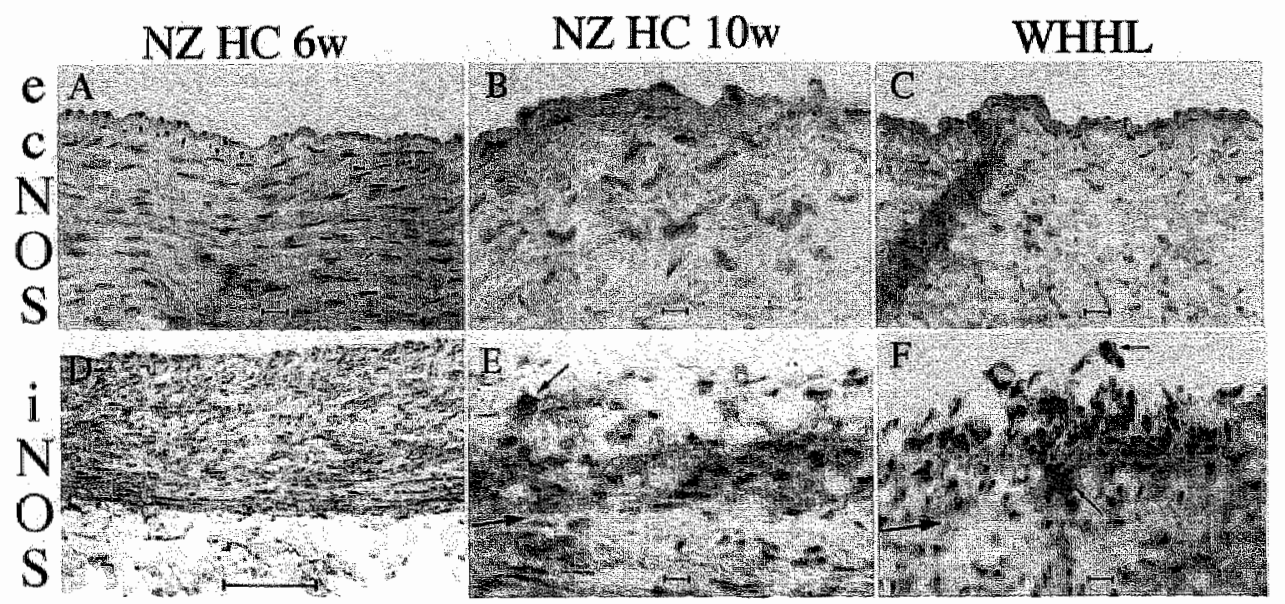

Figure 12. The expression of eCNOS and $\mathrm{NOS}$ in aortic rings of hypercholesterolemic rabbits. EcNOS is clearly present in $\mathrm{NZ}$ after 6 weeks of cholesterol feeding when no intimal thickening is present. The ecNOS in the endothelial layer covering a neointimal lesion, however, is hardly visible. This observation is consistent. with the notion that oxLDL accelerares the degradation of ecNOS mRNA. The macrophages/foamcells in neointimal lesions clearly express iNOS as indicated by the small arrows. The larger arrows indicate the incernal elastic lamina. The scalebar represents $50 \mu \mathrm{m}$. ec: endothelial cell constiturive; $\mathrm{HC}$ : high cholesterol diet; is inducible; NOS: nitric oxide synthase; NZ: New Zealand white rabbit; oxLDL: axidized low density lipoprotein; w: weeks; WHHL: Watanabe heritable hyperlipidemic rabbit. 

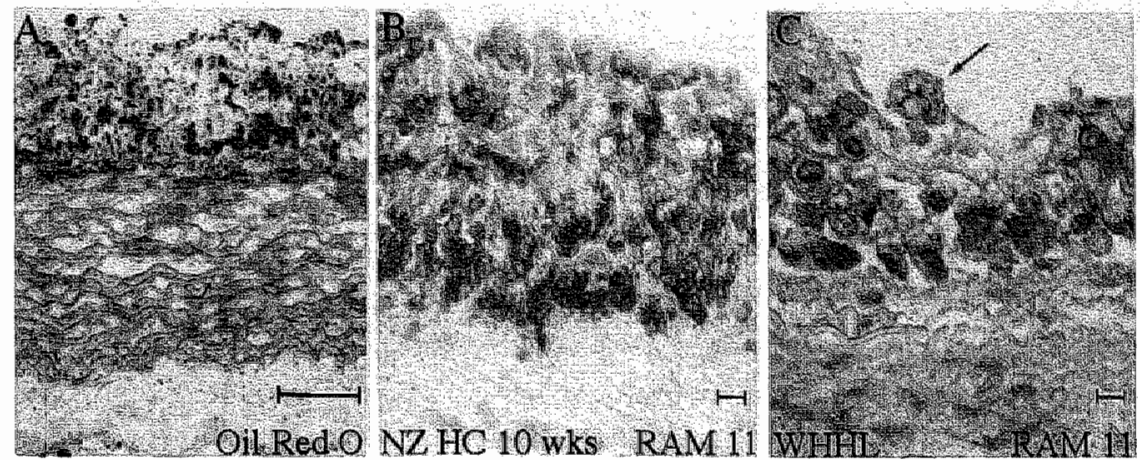

Figure 13. Hypercholesterolemia-induced neointima is predominanty populated by macrophages/foamcells. A: Aortic rings were stained with Oil Red O to localize far deposits. B-C: sections were also stained for soluble RAM 11 (B-C) to identify the presence of macrophages, also indicated with an arrow. The macrophages are packed together in the neointima, however, the media does not contain macrophages. Fat deposition is colocalized with macrophages pointing to the formation of foamcells. The scalebar indicares $50 \mu \mathrm{m}$. HC: high cholesterol diet; NZ: New Zealand white rabbits; RAM: rabbir antibody macrophages; w: weeks; WHHL: Waranabe heritable hyperlipidemic rabbits.
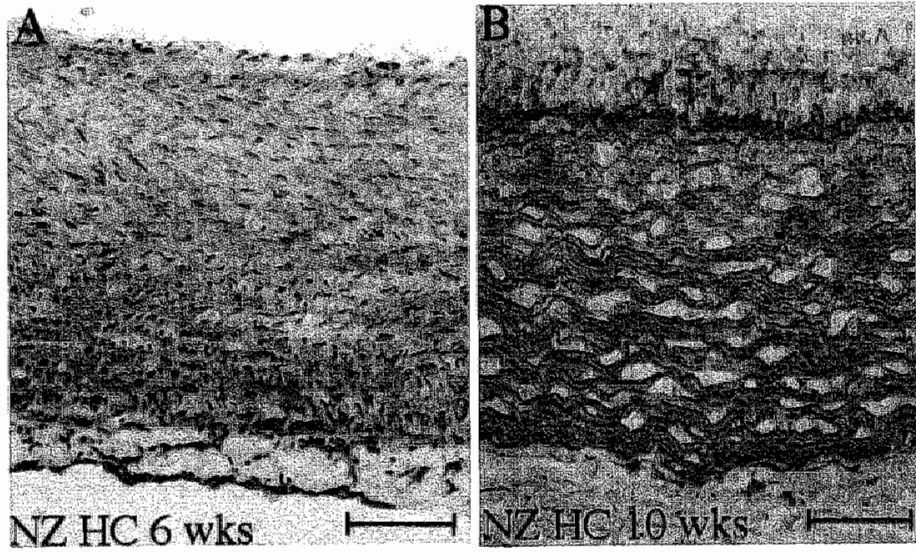

Figure 14. Deposition of nitrotyrosine in aortic rings of hypercholesterolemic rabbits. Six weeks of cholesterol feeding did not cause structural remodeling. Nitrotyrosine is only visible around small adventitial blood vessels. However, in the neointimal lesion that had emerged after 10 weeks of a high cholesterol diet, nitroryrosine is clearly visible in the basal layers of the neointima. The macrophages/foamcells in this area express iNOS and the subsequent increase in $\mathrm{NO}$ release with simultaneous generation of $\mathrm{O}_{2}^{-}$results in the formation of the highly reactive nitrogen oxide radical $O N O O^{\text {. The Teneration of }} \mathrm{NOO}^{-}$is evidenced by the demonstration of nitroryrosine. The scalebar indicares $50 \mu \mathrm{m}$. HC: high cholesterol diet; iNOS: inducible nitric oxide synthase; NZ: New Zealand white rabbit; $\mathrm{O}_{2}{ }^{*}$ : superoxide anion; $O N O O^{-}$: peroxynitrite; wks: weeks. 


\section{Discussion}

From these experiments it can be concluded that hypercholesterolemia increases the release of $\mathrm{NO}$ from the rabbit aorta. This observation is in accordance with the study of Minor and colleagues, who measured NO from rabbit descending thoracic aortas after 5 weeks or 6 months high cholesterol feeding. ${ }^{7}$ Several groups demonstrated a dramatic impairment in the vasodilator activity in these types of vessels despite the marked increase in NO telease. ${ }^{20,21,22,23}$ In the present study, evidence is provided that endorthelium-dependent vasorelaxation can seill be mediated by VEGF/VPF in hypercholesterolemic aortic rings in a dose-dependent fashion. Only after the occurrence of intimal thickening VEGF/VPF fails to induce vasorelaxation. With immunohistochemistry we demonstrated that the neointima predominantly consists of macrophages/foam-cells. These cells account for an increase in NO by almost 10-fold, which results in the formation of other highly reacrive nitrogen oxide radicals with derrimental effects on endothelial cells.

Normally, $\mathrm{NO}$ is continuously released from vascular endothelial cells, involving the conversion of L-arginine to citrulline mediared by a membrane-bound, NADPH-dependent, ecNOS/calmodulin complex. ${ }^{8,9,10}$ The enzymatic activity is responsive to fluctuations in intracellular $\mathrm{Ca}^{2+}$ as evidenced by the action of several reagents, such as ACh and VEGF/VPF, capable of increasing endothelial cell NO-release by increasing cyrosolic $\mathrm{Ca}^{2+} \cdot 1,24,25$

The NO produced in the endothelium exerts many anti-atherogenic features. Endothelium-dependent vasorelaxation is mediated by $\mathrm{NO}$, a potent activator of soluble guanylate cyclase, which causes increased intracellular levels of cyclic GMP and, subsequently, smooth muscle relaxarion. Furthermore, also mediated by increased levels of cyclic GMP, NO has an inhibitory effect on cell proliferation and adhesion. ${ }^{19,26}$ It has been reported, that $\mathrm{NO}$ reduces vascular smooth muscle cell mitogenesis. ${ }^{27,28,29}$ Platelet and leukocyte adhesion to the vascular endothelium and subsequent chemotaxis are also negatively regulated by NO. $30,31,32$

Regarding the anti-atherogenic actions of NO, it seems contradictory that the NOrelease has increased in the thoracic aortas harvested from $N Z W$ rabbirs with diet-induced hypercholesterolemia and in Waranabe rabbits with inherited hyperlipidemia as a result of a lack of the low density lipoprotein (LDL) receptor. One explanation for this observation is the concept that only the release of intart $\mathrm{NO}$ exerts its beneficial actions through increasing cyclic GMP. Several groups have conducted both in witro and in vivo experiments that demonstrate an excess generation of the superoxide anion $\left(\mathrm{O}_{2}{ }^{-}\right)$in cultured cells incubated with native LDL ( $\mathrm{n}-\mathrm{LDL}$ ) and in the wall of hypercholesterolemic vessels. ${ }^{33,34}$ This highly reactive oxygen species has been shown to originate in activated macrophages, neurrophils, vascular endorhelial cells, and pulmonal type II cells. NO is a free radical gas and reacts readily with $\mathrm{O}_{2}^{-}$to yield peroxynitrite (ONOO-), a potent oxidizing molecule involved in several reactions, such as lipoprotein oxidation, inhibition 


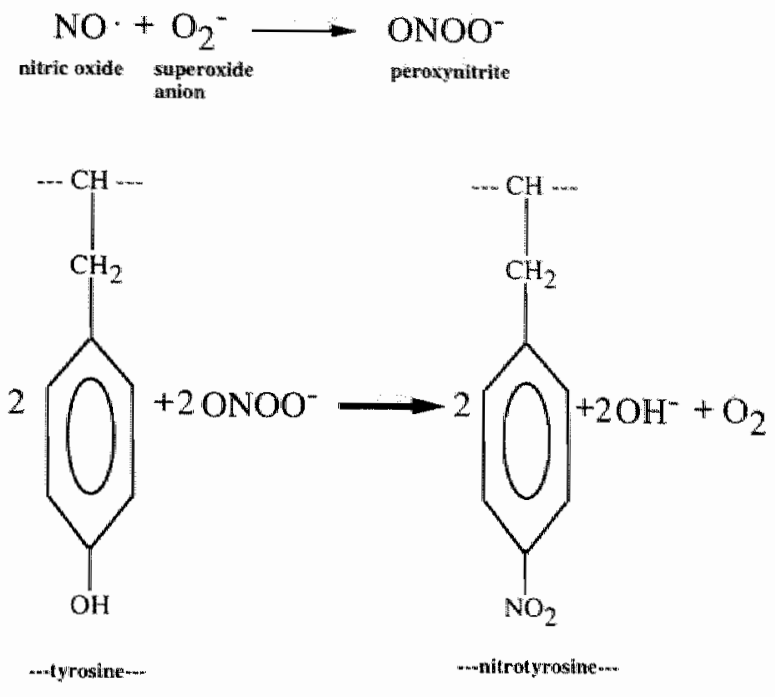

Figure 16. The formation of nitroryrosine after generation of peroxynitrice.

of endothelial cell prostacyclin synthase, increased endothelial cell adhesion ro blood-born cells, and nitration of aromatic amino acids. ${ }^{35,36,37,38} \mathrm{ONOO}$ is only a weak stimulus for soluble guanylate cyclase to produce cyclic GMP. ${ }^{39,40}$ Stimulation of macrophages by cytokines induces the simultaneous production of large amounts of $\mathrm{NO}$ and $\mathrm{O}_{2}{ }^{-}$, resulting in localized formation of $\mathrm{ONOO}$. The invasion of macrophages has been shown to play a crucial role in the initiation of tissue injury in a variety of pathological conditions, particularly in the pathogenesis of a atherosclerotic lesion in response to a hyperlipidemic environment. ${ }^{41,42,43}$

At physiological $\mathrm{pH}$ and temperature, ONOO- has a half-life time of less than I sec. Demonstration of $\mathrm{ONOO}^{-}$in vivo is based on identificarion of stable products of its reaction with several biological compounds. Nitrotyrosine is the stable product of the spontaneous reaction of $\mathrm{ONOO}^{-}$with tyrosine, involving the substitution of the hydroxyl group at the ortho-position of the aromatic ring in tyrosine with a nicro $\left(-\mathrm{NO}_{2}\right)$ group. (Figure 16) ${ }^{35,44}$ The rate of this reaction was determined to be $5 \times 10^{3} \mathrm{M}^{-1} \mathrm{~s}^{-1}$ and thus represents one of the faster reactions for $\mathrm{ONOO}^{-}$reported to date. Furthermore, nitration of tyrosine results in impairment of processes that control signal transduction and regulate cell cycles. ${ }^{45,46}$ Detection of nitrated tyrosine residues by a polyclonal antibody against nitrotyrosine has been verified and has proven to show an excellent relationship berween nitrotyrosine and $\mathrm{ONOO}^{-}$generation. ${ }^{47}$

Endothelial cells in culture exposed to n-LDL produce high rates of both $\mathrm{NO}$ and $\mathrm{O}_{2}$ as demonstrated by deposition of nitroryrosine in the neointima. It has been postulated, that $\mathrm{n}$-LDL uncouples L-arginine metabolism from the actual endothelial cell NO-release 
resulting in an increased generation of $\mathrm{O}_{2}-$ by ecNOS ${ }^{34}$ After feeding NZW rabbits a high cholesterol diet for 6 weeks, we observe an increase in NO production that specifically originated in the endothelium. Removal of $\mathrm{Ca}^{2+}$ from the organ bath solution reduced NO production to levels displayed by rabbits feeding on regular chow. Since only ecNOS, but not iNOS, is sensitive to changes in intracellular $\mathrm{Ca}^{2+}$ concentration, it can be concluded that the increase in NO release after 6 weeks of high cholesterol diet is derived only from endothelial cells. In addition, mechanical removal of the endothelium abolished the increased NO production as well. Other support for this observation are the results of immunohistochemistry, which shows no expression of $\mathrm{NOS}$ in the vascular wall of the rabbits after 6 weeks of a high cholesterol diet. However, an increased homogenous expression of ecNOS in the endorhelial layer was observed. Until now, we have not been able to demonstrate the generation of $\mathrm{O}_{2}^{-}$in wivo, which would have been evidenced by the deposition of nitrotyrosine. In addirion, as opposed to the situation after 10 weeks of high cholesterol feeding, no intimal thickening has occurred, nor are there other morphological changes compared to the aorta of a normal rabbit.

Interestingly, VEGF/VPF, but not $\mathrm{ACh}$, is capable of inducing vasodilatation in the aortic rings harvested from rabbits 6 weeks after a high cholesterol diet. Evidence for the presence of functional VEGF/VPF receptors is obtained since VEGF/VPF further increased NO release when administered to the vascular segments from hyperlipidemic rabbits in the organ chamber. Taken together with the fact that the release of functional $\mathrm{NO}$ depends on the lack of simultaneous $\mathrm{O}_{2}$ - generation ${ }^{48}$, VEGF/VPF apparently augments $\mathrm{NO}$ release without increasing $\mathrm{O}_{2}$ production and thus prevent the formation of the potent oxidant $\mathrm{ONOO}^{-}$. ACh, however, failed to induce vasorelaxation although it stimullated NO release to significantly higher levels. Most likely, in a hyperlipemic vascular segment the release of non-functional $\mathrm{NO}$ was due to inactivation by $\mathrm{O}_{2}$.

The mechanism by which VEGF/VPF reduces the generation of $\mathrm{O}_{2}{ }^{-}$remains unclear. VEGF/VPF binds to its tyrosine kinase receptors Flt-1 and Flk-1/KDR, uniquelly present on endothelial cells, which dimerize to activate downstream signaling. ${ }^{49}$ Activation of phospholipase $\mathrm{C}_{\gamma-1}$ has been shown to cause an increase in cytosolic $\mathrm{Ca}^{2+}$, which is the mechanism for VEGF/VPF" to increase ecNOS activity and subsequently to augment NO release. 24,25 Western blot analysis demonstrates that VEGF/VPF expression is not upregulated in the vessel wall of a hypercholesterolemic rabbit, which is consistent with the observation of Pritchard and colleagues that exposure of endothelial cells in culture to n-LDL did not affecr ecNOS activity as measured by the $\left[{ }^{3} \mathrm{H}\right]$ citrulline assay. ${ }^{34}$ In addition, the expression of ecNOS mRNA in human vascular endothelial cells in vitro did not change when the cells were exposed to increasing concentrations of n-LDL, while shortening of the half-life of ecNOS mRNA significantly decreased its expression when the cells were incubated with oxidized LDL (ox-LDL). 50 These observations support a protective function of VEGF/VPF on vascular endothelium by augmenting the production of intact $\mathrm{NO}$ without simultaneous generation of $\mathrm{O}_{2}{ }^{-}$and subsequently of 


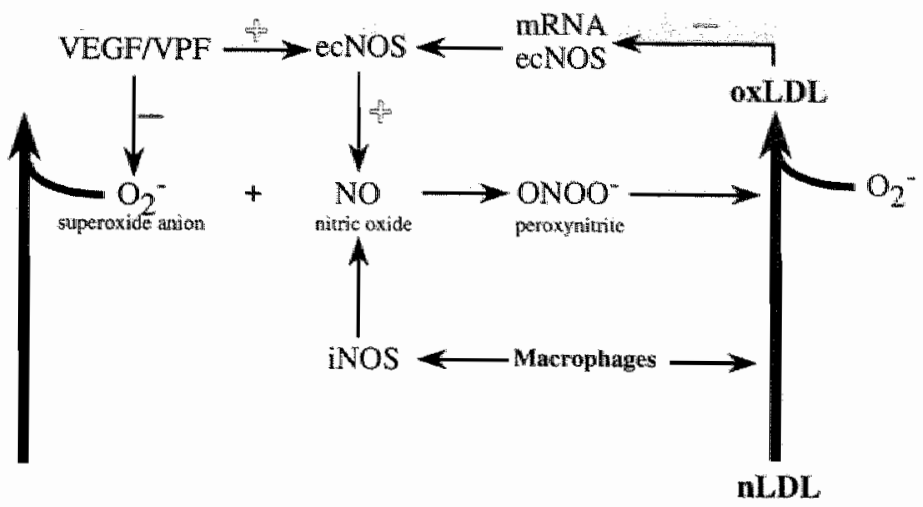

Figure 17. The protecive action of VEGF/VPF on endothelial cells and the detrimental effects of macrophages/foamcells on the vessel wall. VEGFVPPF increases $\mathrm{NO}$ without simultaneously stimulating $\mathrm{O}_{2}^{-}$production, thus preventing the generation of $\mathrm{ONOO}^{-}$. Macrophage/ foancells are capable of inducing both an increase in $\mathrm{NO}$ and $\mathrm{O}_{2}$. The subsequent formation of ONOO' prowides a positiwe feed-back mechanism for further increase in oxidative stress in the vessel wall. See text for further explanation. ece endothellial cell constitutive; i: inducible; LDL: low densiry lipoprotein; n: narve; NOS nitric oxide synthase; $\mathrm{O}_{2}$ : superoxide anion; $\mathrm{ONOO}^{-}$: peroxynitrite; $\mathrm{ox}$ : oxidized; VEGF/VPF: vascular endorhelial growth factor/vascular permeabiliry factor.

ONOO-, because prevention of increasing intracellular oxidative stress reduces the formation of ox-LDL and thus promotes preservation of ecNOS mRNA (Figure 17).

This study does not support the hypothesis that VEGF/VPF mediates chemotaxis of monocytes into the vascular wall, because VEGF/VPF is equally expressed in normal segments and segments with intimal thickening. Ox-LDL and cytokines such as interleukin-1, which are produced by activated macrophages, are known important chemoattractants for monocytes. ${ }^{51}$ In addition, ox-LDL enhances the expression of vascular cell adhesion molecule-1 (VCAM-1), which selectively mediates adherence of monocytes to the endothelium. ${ }^{2}$ VCAM-1 expression has been reported to become expressed as soon as one week after cholesterol feeding. ${ }^{53}$

In endorthelial cells, ecNOS is a membrane-bound enzyme. The membrane associarion is due to the presence of an $\mathrm{N}$-myristoylation sequence. ${ }^{54}$ Myristoylation is the major post-translational modification for ecNOS membrane associarion. However, this localization of some myristoylated proteins is reversible resulting in membrane-bound proteins becoming cytosolic factors. ${ }^{55}$ Previously, it was reported that $\mathrm{n}-\mathrm{LDL}$ increases cell membrane rigidity through donating cholesterol. ${ }^{56.57}$ Changes in membrane lipid dynamics as well as other post-translational modifications might promote ecNOS translocation from membrane to cytosol. ${ }^{54,58}$ This might be an explanation for the homogenous staining of ecNOS in the endothelial layer of the aorta in rabbits after 6 
weeks of high cholesterol feeding. However, the mechanism by which ecNOS causes an increase in $\mathrm{NO}$ release without simultaneous $\mathrm{O}_{2}^{-}$generation after administration of VEGF/VPF needs still to be clarified.

After 10 weeks of cholesterol dier, structural remodeling has occurred in addition to the merely "functional remodeling" after 6 weeks of cholesterol feeding. The plasma cholesterol concentration has risen by 4 -fold, resulting in the development of intimal thickening. Although the expression of VEGF/VPF is not diminished and functional VEGF/VPF receptors still seem to be present, neointimal macrophages/foamcells now are the main source of the increase in baseline $\mathrm{NO}$ release. An almost 10 -fold increase in $\mathrm{NO}$ release is documented in the aortic segments. Removal of $\mathrm{Ca}^{2 *}$ from the organ bath solution does not result in abrogation of this increase pointing to involvement of the Ca-insensirive iNOS instead of ecNOS. Moreover, immunohistochemistry reveals the expression of iNOS throughout the developing neointima, but not in the media.

Interestingly, L-NMMA diminished NO production only by approximately $50 \%$, although it completely abrogated the stimulatory effect of VEGF/VPF on the endothelial cells. The availability of L-NMMA might be better to the endothelium than to the underlying layer of neointimal cells. Furthermore, altered membrane conditions in a hypercholesterolemic environment might interfere with the delivery of L-NMMA to the cytosolic iNOS.

Simultaneous production of $\mathrm{O}_{2}^{-}$and $\mathrm{NO}$ by the macrophages/foamcells, resulting in the formation of $\mathrm{ONOO}^{-}$, further increasing oxidative stress, is demonstrated by the presence of nitrotyrosine, a marker for $\mathrm{ONOO}^{-}$deposition. ${ }^{36,59}$ This is supportive by the finding of colocalization of macrophages/foamcells, iNOS expression, and nitrotyrosine in the emerging atherosclerotic lesion of the rabbit aorta afrer 10 weeks of cholesterol diet.

Similar observations were obtained in age-matched Watanabe rabbits with heritable. instead of diet-induced, hyperlipidemia. Although Watanabe rabbirs display only half of the cholesterol levels compared to the 10 week cholesterol-fed rabbits, the hyperlipidemiainduced remodeling appears to be similar. The presence of macrophage/foamcell, and the colocalization with iNOS and nitrotyrosine is completely idencical. Furthermore, a comparable amount of the VEGF/VPF protein is demonstrated in the vessel wall and functional VEGF/VPF receptors also are preserved in the Watanabe rabbits. Again, as in the 10 week cholesterol-fed rabbits, the protective function of VEGF/VPF on the endothelium is insufficient to restrict the tissue remodeling caused by the implemented oxidative stress generated by the neointimal macrophages/ foancells.

In conclusion, VEGF/VPF preserves the ability of endothelial cells to produce functional $\mathrm{NO}$, which, when not being inacrivated by $\mathrm{O}_{2}$, prevents the subsequent formation of $\mathrm{ONOO}^{-}$, a potent oxidizing molecule involved in the initiation of atherosclerosis in hypercholesterolemic rabbits. When intimal thickening occurs, however, oxidative stress generated by intimal macrophages/foamcells overwhelmes the regulating function of the endothelium. Furure studies are necessary to investigate the 
hypothesis, that amplification of the protective endothelial function, for example by targeting the preserved VEGF/VPF receptors, will delay the development of atherosclerotic lesions in hyperlipemic models.

\section{References}

1. Van der Zee R, Murohara T, Luo Z, Zollmann F, Passeri I, Lekurar C, Isner JM. Vascular endothelial growth factor (VEGF)/vascular permeability facror (VPF) augments nirric oxide release from quiescenr rabbit and human vaseular endothelium. Cinculation 1997;95:1030-1037

2. Jakeman LB, Winer J, Bennett GL, Altar CA, Ferrara N. Binding sires for vaseular endothelial growth factor are localized on endorhelial oells in adult tat rissues. / Cliw 1 waer 1992;89:244-253

3. Alon T, Hemo I, Irin A, Pe'er J, Stone J, Keshet E. Vascular endorhelial growth factor acts as a survival factor for newly formed recinal vessels and has implications for retinoparthy of prematurity. Natume Med $1995 ; 1: 1024-1028$

4. Asahara T, Batuters C, Pastore CJ, Kearney M, Rossow S, Bunting S, Ferrara N, Symes JF, Isner JM. Locall delivery of wascular endothelial growth factor accelerates reendothelialization and antentates intimal hyperplasia in balloon-injured rar carotid artery. Cirulation 1995:91:2793-2801

5. Bauters C, Asahara T, Zheng LP, Takeshita S, Bunting S, Ferrara N, Synes JF, Isner JM. Recovery of disturbed endothelium-dependent flow in the collateral-perfused rabbir ischemic hindlimb after administration of vascular endothelial growth factor. Cimculation 1995;91:2802-2809

6. Sobey CG, Brooks RM, Heistad DD. Evidence that expression of inducible nitric axide synthase in response to endotoxin is augmented in atherosclerotic rabbits. Cxr Res 1995;177:536-543

7. Minor RL, Myers PR, Guerra Jr. R. Bates JN, Harrison DG. Dier-induced atherosclerosis increases the release of nitrogen oxides from rabbit aora. J Clin Invest $1990 ; 86: 2109-2116$

8. Stamler JS, Singel DI, Loscalzo J. Biochemistry of nitric oxide and its redox-activated forms. Science 1992;258:1898-1902

9. Kiechle FL, Malinski T. Nitric oxide. Biochemistry, pathophysiology, and detcecion. Am / Clin Pathol $1993 ; 100: 567-575$

10. Nathan C. Nitric oxide as a secretory product of mammalian cells. FASEB J 1992;6:3051-3064

11. Forstermann U, Mugge A, Acherd U. Haverich A, Frolich $] \mathrm{C}$. Selective autenuation of endotheliummediated vasodilatation in atherosclerotic human coronary antries. Che Res 1988:62: 185-191

12. Cohen RA, Zimay KM, Haudenschild CC, Cunningham LD. Loss of selective endothelial cell wasoactive functions in pig coronary arteries during hypercholesterolemia. Cim Res 1988; 63:903-910

13. James $G$, Olsen EN. Farry acylated proteins as components of intracellular signaling parthways. Biochemitry 1990:29: 2623-2634

14. Wedegaertner PB, Wilson PT, Bourne HR. Lipid modifications of trimeric G protens. I Bul Chesw 1995:270:503-506

15. Wedegaentmer PB, Bourne HR. Acriwation and depalmitoylation of Gs alpha. Cell 199477:10631070.

16. Mumby SM, Gilman AG. Recepror regulation of G-protein palmitoylarion. Pro Nat Acad Sor U SA $1994: 91: 2800-2804$

17. Clauss $\mathrm{M}$, Weich $\mathrm{H}$, Breier $\mathrm{G}$, Knies U, Rockl W, Waltenberger I, Risau W. The wascular endorlhelial growth factor recepror Fit-I mediares biological activiries. Implications for a functional role of placenta growth factor in monocyte activacion and chemotaxis. f Biol Chem 1996;271(30):17629)-17634

18. Barleon B, Sozanni S, Zhou D. Weich HA, Mantovani A. Marme D. Migration of human monocyes in response to vascular endohelial growth factor (VEGE) is mediared wia the VEGF recepror Fit-1. Blood 1996:87:3336-3343 
19. Gruber BL, Marchese MJ, Kew R. Angiogenic facoors stimulate mast-cell migration. Blovd $1995 ; 86: 2488-2493$

20. Freiman PC, Mitchell GC, Heistad DD. Armstrong ML. Harrison DG. Atherosclerosis impairs endothelialdependent vascular relaxarion to acerylcholine and thrombin in primates, Circ Res $1986 ; 58: 783-789$

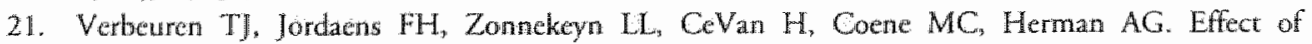
hypercholesterolemia on wascular reactivity in the rabbic. L. Endorhelial-dependent and endorhelial-independerit contractions and relaxations in isolated arteries of control and hypercholestreolemic rabbits. Circ Res $1986,58: 552-564$

22. Harrison DG, Freiman $\mathrm{PC}$, Armstrong ML, Marcus ML, Heistad DD. Alterations of vascular reactivity in atherosclerosis. Citc Res 1987;61(Suppl 11):II-74-II-80

23. Forstermann U, Mügge A, Acheid U, Haverich $A$, Frolich JC. Selecrive attenuation of endorhelialmediated vasodilation in atherosderotic human coronary arteries. Circ Res 1988;62:185-190

24. Brock TA. Dvorak HF, Senger DR. Tumor-secreted vascular permeability factor increases cytosolic $\mathrm{Ca}^{2+}$ and von Willebrand factor release in thuman endorhelial cells. Am J Pathol 1991;138:213-221

25. Ku DD, Zaleski JK, Liu S, Brock TA. Vascular permeability factor induces EDRF-dependent relaxation in coronary arteries. Am / Physiol 1993;265:H586-H592

26. Lowenstein CJ, Dinerman JL, Snyder SH. Nitric oxide: a physiologic messenger. Ann Intern Med $1994 ; 120: 227-237$

27. Grarg LC, Hassid A. Niric oxide-generaring vasodilators and 8-bromo-cyclic guanosine monophosphate imhibit mitogenesis and proliferarion of cultured rat wascular smooth muscle cells. JClin Invest $1989 ; 83: 1774$-1777

28. Scott-Burden T, Schini VB, Elizondo E, Junquero DC, Vanhoutte PM. Platelet-derived growrh faccor suppresses and fibroblase growth factor enlataces cytokine-induced production of nitric oxide by cultured smooth muscle cells: effects on cell proliferation. Circ Res 1992;71:1088-1100

29. Cooke JP "Singer AH, Isao P, Zera P, Rowam RA, Billingham ME. Antiatherogenic effects of t-arginine in the hypercholesterolemic rabbit. / Clin Invest 1992;90:1168-1172

30. Radomski MW, Palmer RMJ, Moncada S. An L-arginine/nitric oxide pathway present in human platelers regulates aggregation. Proc Nat/ Acad Sci U S A 1990;87:5193-5197

31. Radomski MW, Palmer RMJ, Moncada S. Endogenous nitric oxide inhibits human plateler adthesion ro vascular endorhelium. Lancet 1987;2:1057-1058

32. Kubes P, Suzuki M, Granger DN. Nitric oxide, an endogenous modulator of leukocyte adhesion. Proc Nati Acad Sir U SA 1991:88:4651-4655

33. Ohara J. Pererson "TE. Harrison DG. Hypercholesterolemia increases endothelial superoxide anion production. / Clin lnwest 1993,91:2546-2551

34. P’richard KA Jr, Groszek L, Smalley DM, Sessa WC, Wu M, Villalon P. Wolin MS, Stemerman MB. Native low-density lipoprotein increases endothelial cell nitric oxide synthase generation of superoxide anion. Cim Res 1995;77:510-518

35. Pryor WA. Squadrito GL. The chemistry of peroxynirrite: a producr from the reaction of nirric oxide with superoxide. Am / Pbysiol 1995:268:L699-L/222

36. Miles AM, Bohle DS, Glassbrenner PA, Hansert B, Wink DA, Grisham MB. Modulation of superoxidedependent oxidation and hydroxylation reactions by nitric oxide. J Biol Cheng 1996; $271(1): 40-47$

37. Zou MH, Ullrich V. Peroxynitrite formed by simultaneous generation of nitric oxide and superoxide selectively inhibits bovine aortic prostacyclin synthase. FEBS Lett 1996;382:101-104

38. Nit $X$, Smith CW, Kubes P. Intracellular oxidarive stress induced by nitric oxide synthesis inhibition increases crodothelial cell addesion to neutrophils. Cm Res 1994:74:11.33-1140

39. Mayer B, Schrammel A, Klatt P. Koesling D. Schmidt K. Peroxynicrite-induced accumulation of cyclic GMP in endothelial cells and stimulation of purified soluble guanylyl cyclase. $\int$ Biol Chem $1995 ; 270: 17355-17360$ 
40. Tarpey MM, Beckman IS, Ischiropoulos H, Gore JZ, Brock TA. Peroxynitrite stimulates wascular smooth muscle cell cyclic GMP synthesis. FEBS Lett 1995;364:314-318

41. Gown $A_{0}$ Tsukada T, Ross R. Human atherosclerosis II: immunocytochemical analysis of the cellular composirion of human atherosclerotic lesions. Am f Pathol 1986:125:191-207

42. Navab M, Imes SS, Hama SY, Hough GP, Ross LA, Bork RW, Valente Al, Berliner JA, Drinkwater DC. Laks H. Fogelman AM. Monocyte transmigration induced by modification of low density lipoprotein in cocultures of human aortic wall cells is due to induction of monocyte chemowactic protein-I synthesis and is abolished by high density lipoprotein. J Clin Invest 1991;88: 2039-2046

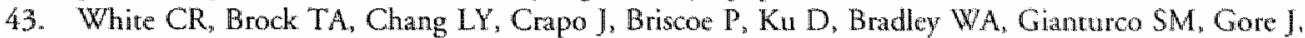
Freeman BA, Tarpey MM. Superoxide and peroxynitrite in atherosclerosis. Proc Nat Asod Sai USA 1994;91:1044-1048

44. Ischiropoulos $\mathrm{H}, \mathrm{Al}-\mathrm{Me}$ di AB. Peroxynitrite-mediated oxidative protein modifications. FEBS Lett 1995;364:279-282

45. Kong SK, Yim MB, Stadtman ER, Chock PB. Peroxynitrite disables the tyrosine phosphorylation regulatory mechanism: lymphocyte-specific ryrosine kinase fails to phosphorylare nicrated cde 2(6-20) $\mathrm{NH}_{2}$ pepride. Proc Nat Acad Sci U SA 1996;93:3377-3382

46. Gow AJ, Duran D, Malcolm $S$, Ischiropoulos $\mathrm{H}$. Effects of peroxynitrite-induced protein modification on tyrosine phosphorylation and degradation. FEBS Lett 1996;385:63-66

47. Haddad IY, Pataki G, Hu P, Galliani C, Beckman JS, Matalon S. Quantitation of nitrongrosine levels in lung sections of patients and animals with acure lung injury. I Clin Inwest 1994;94:2407-2413

48. Rubbo H, Radi R, Trujillo M, Telleri R, Kalyanaraman B, Barnes S, Kirk M, Freeman BA. Nitric oxide regulation of superoxide and peroxynitrite-dependent lipid peroxidation. Formation of novel nitrogencontaining lipid derivares. / Biol Chem 1994:269:26066-26075

49. Claffey KP, Senger DR, Spiegelman BM. Structural requirements for dimerization, glycosylation, secretion, and biological function of VPF/VEGF. Biochem Biophys Acta 1995; 1246:1-9

50. Liao JK, Shin W/, Lee WrY, Clark SL. Oxidized low-density lipoprotein decreases the expression of endorhelial nitric oxide synthase. J Biol Chem 1995;270:319-324

51. Berliner JA, Territo MC, Sevanian A, Ramin S, Kim \A, Bamshald B, Esterson M, Fogelman AM. Minimally modified low density lipoprotein stimulates monocyte endothelial interactions. J Clin Inwest $1990 ; 85: 1260-1266$

52. Elices MJ, Osborn L, Takada Y", Crouse C, Luhowskyj S, Hemler ME, Lobb RR. VCAM- 1, an acriwated endothelial cell adhesion molecule, inceracts with the leukocyte integrin VLA-4 at a site distinct from the VLA-4/fibronectin binding site. Cell 1990;60:577-584

53. Li H. Cybulsky M1, Gimbrone MA Ir, Libby P. An atherogenic dier vapidly induces VCAM-1. a cytokine regulatable mononuclear leukocyte adhesion molecule, in rabbir aortic endothelium. Arterioscler Thromb 1993;13:197-2044

54. Sessa WC. Barber CM, Lynch KR. Mutation of $N$-myrisroylarion site converts endothelial cell mitric oxide synthase from a membrane to a cytosolic protein. Circ Res 1993;72:9211-924

55. Busconi L, Michel T. Endorhelal nitric oxide synthase membrane targeting. Evidence against involvement of a specific myristate receptor. J Biol Chem 1994:269:25016-25020

56. Song J, Waugh RE. Bending rigidity of SOPC membranes containing cholesterol. Bophys $f$ $1993 ; 64: 1967-79$

57. Sairo H. Minamida T. Arimoto 1. Handa T, Miyajima K. Physical stares of surface and core lipids in lipid emulsions and apol ipoprotein binding to the emulsion surface. J Bin/ Chem 1996:271(26):1551515520

58. Robinson L.J. Busconi L, Michel. Agonist-modulated palmitoylation of endothelial nitric oxide synthase. J Biol Chem 1994;270(3):995-998

59. Szabó C, Salzman AL, Ischiropoulos H. Endotoxin triggers the expression of an inducible isoform of nitric oxide synthase and the formarion of peroxynitrite in rat aorta in vivo. FEBS Let 1995:363:235238 



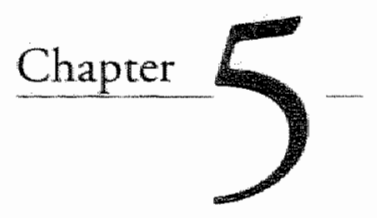

\section{Vascular Endothelial Growth Factor / Vascular Permeability Factor Prevents Peroxynitrite-Induced Apoptosis in Endothelial Cells}

Rien van der Zee, MD; Jonathan Passeri, BA; Alison Sullivan, MS; Hal Skopicki, MD, PhD; Jeffrey M. Isner, MD

From the Departments of Biomedical Research and Medicine (Cardiology), St. Elizabeth"s Medical Center, "Tufts University, School of Medicine, Boston, Mass 02135

Rien van der Zee is a recipient of a traveling grant of the Wynand N. Pon Foundation.

Submitted as full paper; accepted as abstract in Circulation 1997. 


\section{Abstract}

Intimal lesions occurring in bypercholesterolenta are associated with the generation of potent oxidizing nitrogen oxides. Since oxidants are known inducers of apoptosis and several grow bactors activating protein tyrosine binase receptors prevent apoptosis, we bypothesized that vascular endothelial growth factorlvascular permeability factor (VEGFIVPF) likewise prevents endathelialcoll (EC) apoptosis in bypercholesterolemia.

Culwred ECs and smooth muscle cells (SMCs) were exposed to, (a) graded concentrations of peroxynitrite $\left(\mathrm{ONOO}^{-}\right)_{n}$ (b) ONOO- + VEGF/VPF, and (c) ONOO + VEGFIVPF + the phosphatidylinositol-3' (PI-3) kinase inhibitor, wormannin. Apoptosis was demonstrated by enzymatic Labeling of DNA fragmentation (TUNEL) and quantified. Peroxynitrite induced apoptosis in both cell types. VEGF/NF significantly reduced the number of apoptatic figures in ECs. This effect wats abrogated by co-administration of wortmannin, indicating the requirement for PI-3 kimase. VEGF/VPF exented no effect on SMC apopiosis.

The generation of peroxynitrite in wivo was demonstrated by nitrotyrosine deposition in artic intimal lesions from bypercholesterolemic mbbits. Intimal thickening was observed, consisting of SMCs and macrophages/foam cells. In addition, apoptosis was demonstrated by the TUNEL-method, transmission electron microscopy, and agarose gel electrophoresis of genomic DNA.

In conclusion, VEGF/VPF reduces peroxynitrite-induced apoptosis of ECs, requiring PI-3 kinase. VEGF/VPF did not decrease apoptosis of SMCs, thus reducing intimal thickening in bypercholesterolemia. 
An important feature of preserving tissue integrity is the regulation of cell death and cell proliferation.' Tissue homeostasis is maintained as a resulc of a complex regulatory system with numerous checks and balances. Physiologic cell death or apoprosis occurs through controlled autodigestion of the cell and/or through ingestion by macrophages, both of which involving activation of endogenous proteases and endonucleases. ${ }^{2,3,4,5,6}$ In many cell rypes undergoing apoptosis, DNA is degraded into fragments. Consequently, identification of apoptosis in tissue specimens or in cultured cells has been made possible by enzymatic labeling of nuclear DNA fragmentation with terminal deoxynucleotidyl transferase $(\mathrm{TdT})$, based on incorporation of labeled nucleotids at sites of DNA breaks. $7.8,9$

A variety of extrinsic and intrinsic signals is known to oppose cell proliferation by inducing apoptosis. ${ }^{10,11,12}$ Damage-relared inducers of apoptosis are, amongst others, oxidants and radicals. 13,14,15,16 Previously, we reported on the generation of the potent oxidative free radical peroxynitrite (ONOO- ${ }^{-}$in neointimal lesions of the thoracic aorta in hypercholesterolemic rabbits. ${ }^{17}$ Furthermore, evidence was provided that vascular endothelial growth factor (VEGF)/vascular permeability factor (VPF) preserved the vasomotor response of hypercholesterolemia-exposed vessels without neointimal thickening. ${ }^{17,18}$ However, the putative function of VEGF/VPF on vascular endothelium is overwhelmed by $\mathrm{ONOO}^{-}$-generation in the developing neointima that emerged after the rabbits had been exposed to a high cholesterol diet for a longer period of time.

We now hypothesize that, apart from augmenting nitric oxide (NO), VEGF/VPF displays another protective action in preserving vascular integrity by mediating a survival signal for endothelial cells (ECs).

Recently, Yao and Cooper have demonstrated the requirement for phosphatidylinositol-3' (PI-3) kinase in the prevention of apoptosis by nerve growth factor (NGF) and platelet derived growth factor (PDGF). ${ }^{19}$ Interestingly, apoptosis is also prevented by epidermal growth facror (EGF), insulin-like growth factor-1 (IGF-1), or insulin, all of which are known activators of protein tyrosine kinase receptors, $20,21,22,23$ Consequently, in the present study, we establish the prevention of ONOO-induced apoptosis in vascular endothelial cells by VEGF/VPF, which is another protein tyrosine kinase activating growth factor, ${ }^{24,25}$ In addition, similar to NGF, PDGF, IGF-1, and $\mathrm{EGF}$, evidence is presented that VEGF/VPF mediates cell survival involving a PI-3 kinase signaling parhway.

\section{Methods}

\section{Reagents}

All reagents and chemicals including the PI-3 kinase inhibitor wortmannin were purchased from Sigma Chemical Co. (Sr Louis, MO), except peroxynitrite and its 
negative control, which was provided by the Alexis Corporation (San Diego, CA). Heterodimeric recombinant human VEGF/VPF, purified from Escherichia Coli, was a gift of Napoleon Ferrara and Stuart Bunting, Genentech, South San Fransisco, CA. 3-Amino-9-ethyl-carbazole (AEC) was purchased from Biogenex (San Ramon, CA). Culture media were obtained from Life Technologies (Gaithersburg, MD), unless stated otherwise. The antibodies used for immuno-histochemistry were: mouse monoclonal anti-nitrotyrosine (Upstate Biotechnology Inc, Lake Placid, NY), mouse monoclonal CD31 (DAKO, Carpinteria, CA), mouse monoclonal anti- $\alpha$ smooth muscle actin conjugated to alkaline phosphatase (Sigma), and biotinylated GSL I-isolectin B4 (Vector Laboratories, Burlingame, CA). If applicable, secondary antibodies were applied derived from the Ultra Streptavidin Level2 Kit (Signet, Dedham, MA). The specificity of the antibodies is reported in the manual of the providing companies. The In Situ Cell Death Detection Kit (Boehringer Mannheim, Mannheim, Germany) was used for detection of apoptosis.

\section{Cell culture}

The thoracic aorta was harvested from regular New Zealand white (NZW) rabbits, NZW rabbits that had been subjected to a high cholesterol diet, and age-matched Watanabe heritable hyperlipidemic (WHHL) rabbits. The aortic ECs were harvested by scraping the luminal side of the excised thoracic aorta. The ECs in the removed fragments were placed in 4-well fibronectin-coated slides (Fisher Scientific, Pittsburg, PA) and cells were allowed to proliferate cultured in M199 medium (Fisher Scientific) supplemented with $20 \%$ heat-inactivated fetal bovine serum (FBS), $12 \mu \mathrm{g} / \mathrm{ml}$ bovine brain extract (Clonetics, San Diego, CA), and antibiotics. ECs were identified with immunohistochemical staining of CD31 (data not shown). They were used for experiments after the second passage.

Rabbit aortic smooth muscle cells (SMCs) were derived from $3 \mathrm{~mm}$ aortic segments, that were placed with the luminal side onto fibronectin coated dishes after the endorhelium was mechanically removed as described above. The vaseular SMCs proliferated in DMEM supplemented with $10 \% \mathrm{FBS}$ and antibiotics. Cells were maintained in a culture incubator at $37^{\circ} \mathrm{C}$ under a $5 \% \mathrm{CO}_{2}$ humidified atmosphere and were used on second or third passage. Cells were maintained at confluence for 2 to 3 days prior to experiments in 4-well fibronectin-coared slides (Fisher Scientific).

$\mathrm{ONOO}^{-}$in $0.3 \mathrm{M} \mathrm{NaOH}$ was added in increasing concentrations ranging from 1 nmol// to $1000 \mathrm{nmol} / \mathrm{l}$. To avoid rapid decomposition, $\mathrm{ONOO}^{-}$was buffered in 50 mmol/l Tris and phosphate-buffered solution (PBS) without $\mathrm{Ca}^{2+}, \mathrm{pH} 8.7$. At $\mathrm{pH} 7.4$ protonation of peroxynitrite induced rapid decomposition principally ro nitrate $\left(\mathrm{NO}_{3}{ }^{-}\right.$). Before use, the $\mathrm{ONOO}^{-}$concentration was monitored by measuring the increase in absorbance at $302 \mathrm{~nm}\left(\mathrm{E}_{302 \mathrm{~nm}}=1.67 \mathrm{mmol} / \mathrm{l} \cdot \mathrm{cm}\right)$ after addition of $5 \mu \mathrm{l}$ of stock $\mathrm{ONOO}^{-}$ in $3 \mathrm{ml}$ of $1 \mathrm{~N} \mathrm{NaOH}$. For control, the same volume of $\mathrm{NNOO}^{-}$was added to the buffer used for the experiments. In order to avoid $\mathrm{pH}$ changes in the culture media, small 
volumes of $\mathrm{ONOO}^{-}$were employed. To account for the effects of nitrite, hydrogen peroxide, and $\mathrm{NaCl}$, a negarive control solution was administered, containing the decomposed form of $\mathrm{ONOO}^{-}$prepared from the same stock as the active form. The negative control contained the same concentrations of nitrite, hydrogen peroxide and salr, but had no absorbance at $302 \mathrm{~nm}$ under alkaline conditions.

For some experiments, $100 \mathrm{ng} / \mathrm{ml}$ VEGF/VPF was added either alone or in combination with $0.1 \mu$ mol/I wortmannin. This dose of wortmannin has been shown to specifically inhibit phosphatidylinositol-3' (PI-3) kinase. ${ }^{22}$

\section{Analysis of apoptosis in vitro}

Analysis of the 4-well slides containing either vascular SMCs or ECs was performed withour knowledge of the reagents added to the wells. The total number of cells per well was calculated by counting an area of the well in which no apoptosis was identified. The counring was facilitated by projection of the microscopic image on a large screen (Microscope Slide Projector XM160, Stahl Research Laboratories Inc, Port Chester, NY). Apoptotic cells were discriminated by the presence of condensed dark blue nuclei in contrast to either healthy or necrotic cells, ${ }^{7,89}$ All wells were independently counted twice by two different persons. The variation between the two observers and counts was less

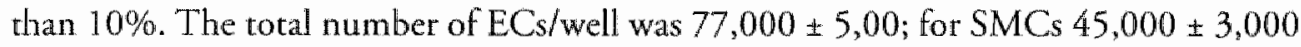
cells. Values are presented \pm standard error of the mean (SEM).

\section{Animal protocol}

Experiments were performed on the thoracic aorta isolated from NZW rabbits or from age-matched Watanabe heritable hyperlipidemic (WHHL) rabbits. Only male rabbits were used to avoid variations in outcome arrributable to gender alone. The experimental protocol described was conducted according to protocols approved by the St Elizabeth's Institutional Animal Care and Use Committee. Hypercholesterolemia was induced by feeding a $1 \%$ cholesterol diet for $6(n=6)$ and 10 weeks $(n=6)$. Age-matched controls $(n=6)$ and WHHL rabbits ( $\mathrm{n}=6$ ) were maintained on standard chow. The NZW rabbits were randomly assigned to the different groups.

Harvesting and preparing the thoracic aorta was conducted as described previously. ${ }^{18}$ In shorr, the rabbits were killed by exsanguinarion. Blood was collected from all rabbits to determine total serum cholesterol with an automatic analyzer (Kodak 700 , Johnson and Johnson, Rochester, NY). Immediately after cessation of respiration, the thorax was opened and the aorta was excised from aortic walve to diaphragmatic hiatus. Connective and other adhesive rissue was removed and the vessels were washed initially in PBS.

Then, the aorta was subdivided; the proximal part ( $n=4 /$ group), most prone to lesion formation at early stage ${ }^{26}$, was used for morphologic studies. This part was embedded in OCT compound (Miles Inc, Elkhart, IN), frozen in liquid nitrogen, and stored at -70 ${ }^{\circ} \mathrm{C}$ until it was used for immunohistochemistry or nick-end labeling of DNA fragments. 
The remaining part was used for transmission electron microscopy after fixing in $2.5 \%$ gluteraldehyde ( $\mathrm{pH} 7.3)$, buffered with $0.1 \mathrm{~mol} / \mathrm{l}$ sodium cacodylate at $4^{\circ} \mathrm{C}$ for at least 1 hour.

\section{Analysis of apoptosis in vivo}

Air dried frozen $6 \mu \mathrm{m}$ sections were fixed with fresh $4 \%$ paraformaldehyde $(\mathrm{pH} 7.4)$ for $30 \mathrm{~min}$. After 2 washes, the tissue was permeabilized with $0.1 \%$ Triton X-100/PBS for 2 min at $4^{\circ} \mathrm{C}$ and washed again. Thereafrer, the slides were incubated with $T d T$ derived from calf thymus and fluorescein-labeled nucleotides antibody conjugated with alkaline phophatase for $30 \mathrm{~min}$ at $37{ }^{\circ} \mathrm{C}$, washed again, and for $15 \mathrm{~min}$ incubated with 5-bromo-4-chloro-3-indolylphophatase p-toluisine salt and nitroblue tetrazolium, which causes a dark blue color at the site of the incorporated fluorescein-labeled nucleorides. The slides were washed in PBS again and coverslipped with glycerol gelatin mounting medium. Positive controls were obtained by pretreatment with DNase: after immersion in DN-buffer ( $30 \mathrm{mmol} / 1$ Trizma base, $\mathrm{pH} 7.2 ; 140 \mathrm{mmol} / \mathrm{l}$ sodium cacodylate; $4 \mathrm{mmol} / \mathrm{l}$. $\mathrm{MgCl}_{2}$ ) for $5 \mathrm{~min}$, the slides were covered with $1 \mu \mathrm{g} / \mathrm{ml}$ DNase dissolved in DN-buffer at 1:10 dilution. After $10 \mathrm{~min}$, the slides were washed and nick-end labeled as described above. For negative controls, the slides were processed without incubation of TdT.

In arteries harvested from hypercholesterolemic rabbits and their controls kept on regular chow, apoptosis was evaluated by agarose gel electrophoresis of genomic DNA performed to identify ladders of fragmented DNA.

\section{Immunobistochemistry}

After DNA nick-end labeling, the 4-well slides containing either SMCs or ECs were further incubated with respectively a mouse monoclonal anti- $\alpha$ smooth muscle actin antibody conjugated to alkaline phosphatase or with biotinylated GSL I-isolectin B4 to respectively identify $\mathrm{SMC}-$ actin or EC membrane glycoprotein lectin. Bound primary antibody was decected with 4-chloro-2-methylbenzenediazonium/3-hydroxy-2-naphroic acid 2,4-dimethylanilide phosphate (Fast Red TR/Naphtol AS-MX, Sigma).

For detection of nitrotysrosine, tissue was fixed and permeabilized ar $-20^{\circ} \mathrm{C}$ for $5 \mathrm{~min}$ in $100 \%$ methanol. Endogenous peroxidase activity was blocked with $3 \% \mathrm{H}_{2} \mathrm{O}_{2}$ for 5 min, and rissue was treated with normal horse serum to prevent non-specific binding of biotinylared horse anti-mouse immunoglobulins, which were applied as secondary antibody. Then, the slides were incubated with mouse anti-nitrotyrosine antibody (1 hour at $37^{\circ} \mathrm{C}$, diluted $1: 100$ in $1 \%$ bovine serum albumin (BSA)/PBS). For negative controls equal amounts of non-specific mouse anti-rabbir $\operatorname{IgG}_{1}(\mathrm{MOPC}-21)$ was applied. After application of the secondary antibody and streptavidin-horseradish peroxidase, the slides were incubated with AEC causing a red color. The tissue was counterstained with hematoxylin and coverslipped with glycerol gelatin mounting medium. 
The Oil Red O reaction for fat was performed on $6 \mu \mathrm{m}$ frozen sections of the wascular segments. Adjacent sections were stained for $\alpha$-actin to identify smooth muscle cells.

\section{Transmission electron microscopy}

Porrions of thoracic aorta from 4 cholesterol-fed, 4 WHHL rabbits, and 4 control rabbits were postfixed with $1 \%$ osmium tetroxide. Then, the tissues were dehydrated with increasing concentrations of alcohol, followed by saturation with propylene oxide for 15 min. Thereafter, the tissue was gradually infiltrated with Epon and finally embedded with fresh Epon into molds and heated in a $60^{\circ} \mathrm{C}$ oven for 24 hours. Several sections were stained with toluidine blue, and three ultrathin sections of the areas of interest were stained with uranyl acetate and lead citrate for examination with a Philips 300 electron microscope.

\section{Results}

\section{Apoptosis in vitro}

Peroxynitrite added to either SMCs or ECs in culture causes apoptosis (Figure 1). At the tested $\mathrm{ONOO}^{-}$concentrations no differences were observed between cells harvested from hypercholesterolemic rabbits or rabbits kept on regular chow (data not shown). The

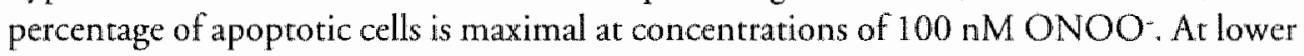
concentrations most cells survive unaffected. At the highest concentrations immediate massive necrotic cell death occurs, importantly diminishing the number of apoptotic cells. VEGF/VPF significantly reduces the percentage of apoptosis in ECs when ONOO- is

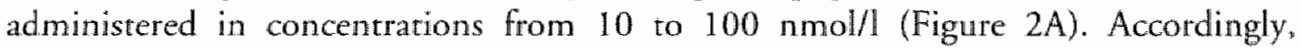
VEGF/VPF exerts no significant protective action at ONOO- concentrations of 1000 nmol/l, when necrosis is the most important mode of cell death.

Similar to NGF, PDGF, ECF, and IGF-1, evidence is provided that Pl-3 kinase is integral in the parhway by which VEGF/VPF, another growth factor acring on protein tyrosine kinase receptors, prevents apoptosis. When ECs are co-incubated with VEGF/VPF and $0.1 \mu \mathrm{mol} / \mathrm{PI}-3$ kinase inhibitor wortmannin, the protective action that VEGF/VPF exerts in reducing the percentage of apoptotic death is almost completely abrogated (Figure 2B).

As expected, VEGF/VPF has no significant effect on SMCs, confirming that the VEGF/VPF-receptors Flk-1/KDR and $f t$ t- 1 are uniquely present on $\mathrm{ECs}^{24}$ (Figure 3).

\section{Apoptosis in tivo}

The in vitro findings were confirmed in vivo, using a hypercholesterolemic rabbit model, which previously has been shown to involve neointimal thickening. ${ }^{17}$ In the intimal lesion 


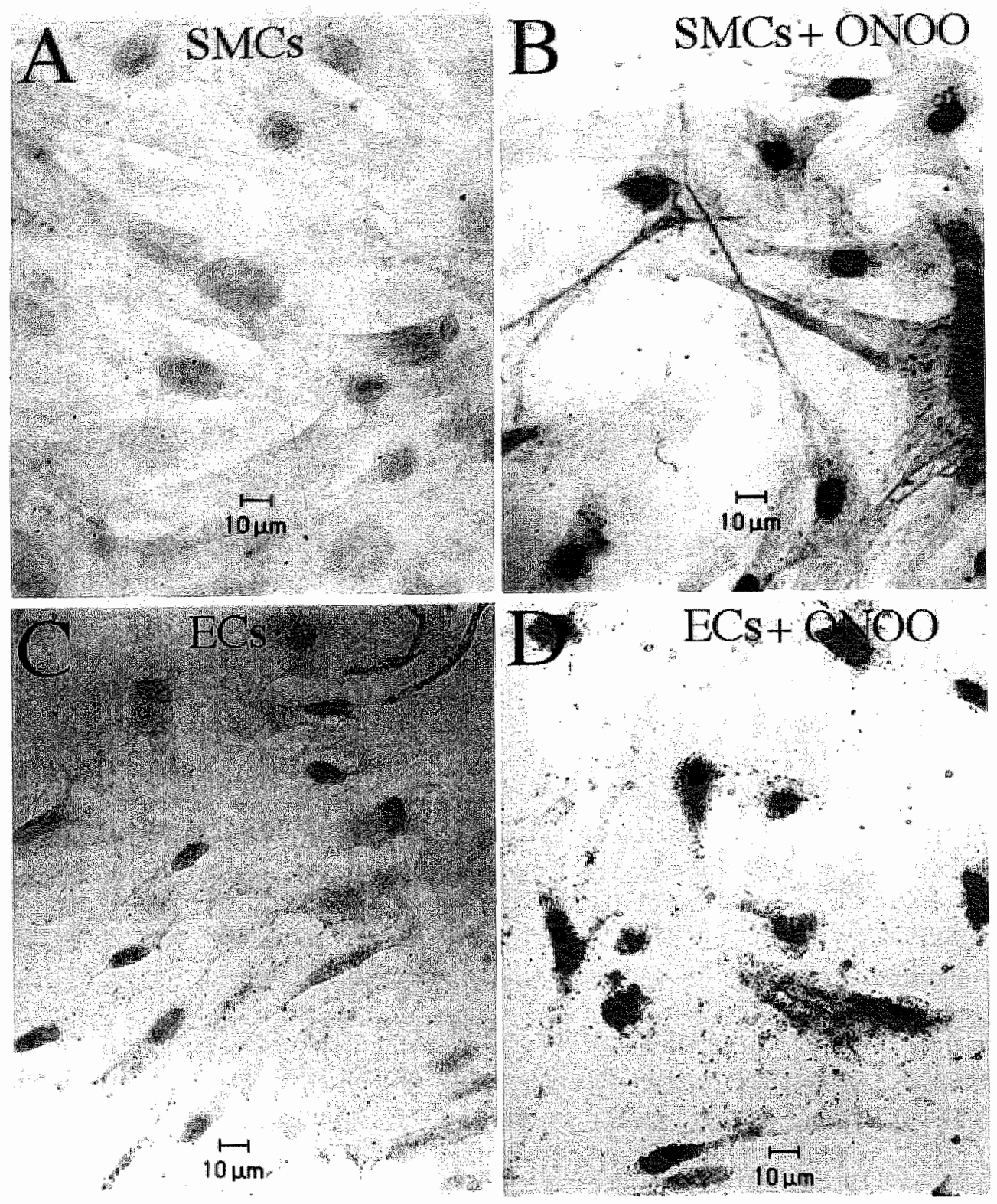

Figure 1. Peroxynitrite (ONOO, $100 \mathrm{nM}$ ) induces apoptosis in representative examples of cultures with smooth muscle cells (SMCs) or endothelial cells (ECs). Only dark blue condensed nudei were discriminated for quantification. Cells in which nuclei were not longer visible (D) were nor identified as apoptoric cells. 


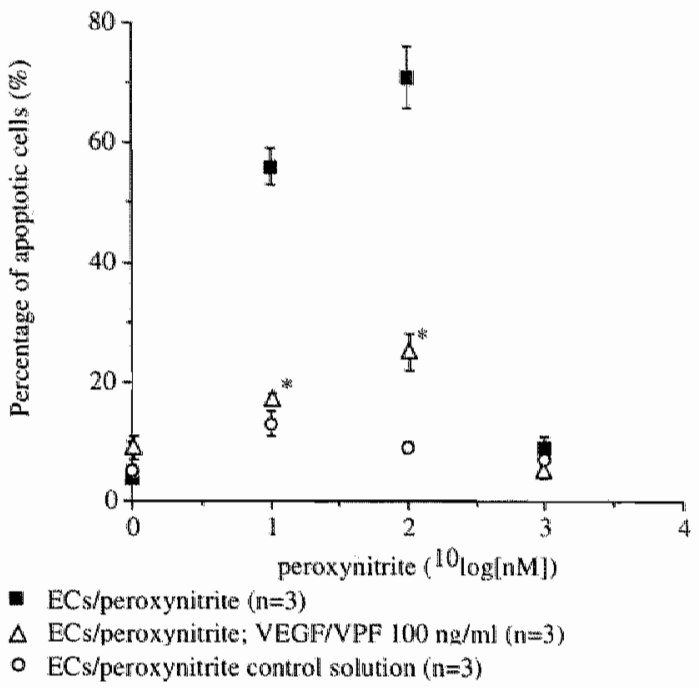

Figure 2A. VEGF/VPF protects endothelial cells in a confluent monolayer from undergoing apoprosis when exposed to peroxynitrite for 48 hours. " $: p<0.05$ versus 'ECs/peroxynitrite". ECs: endothelial cells; VEGFIVPF: vascular endothelial growh factor/vascular permeability factor; control refers to a solution containing the decomposed form of peroxynitrite prepared from the same stock solution as the active form; $n$ represents the number of wells exposed to defined reagents.

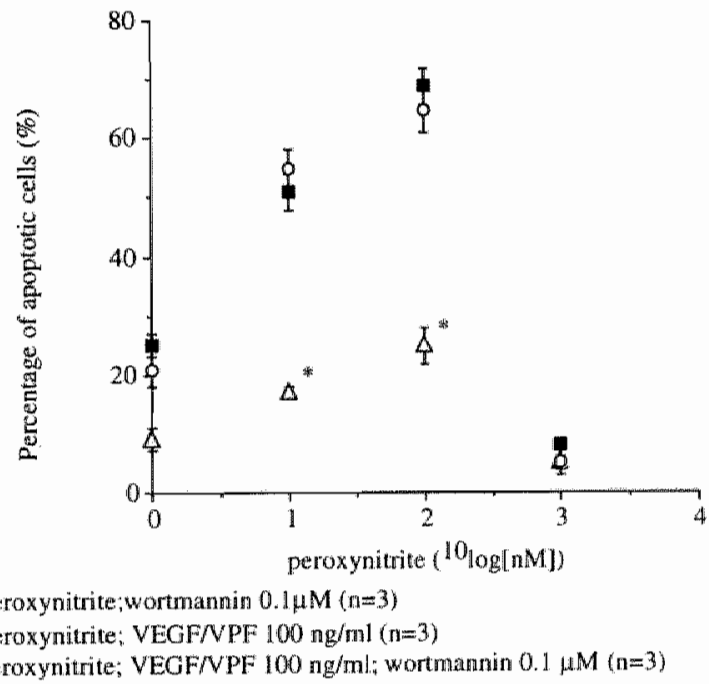

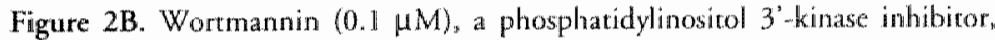
significantly abolishes the effecr of VEGF/VPF on endothelial cells. ": $\mathrm{p}<0.05$ versus other values at indicated concentrations. ECs: endothelaal cells; VEGF/VPF: vascular endothelial growth factor/vascular permeability facrord, $n$ represents the number of wells exposed to defined reagents. 


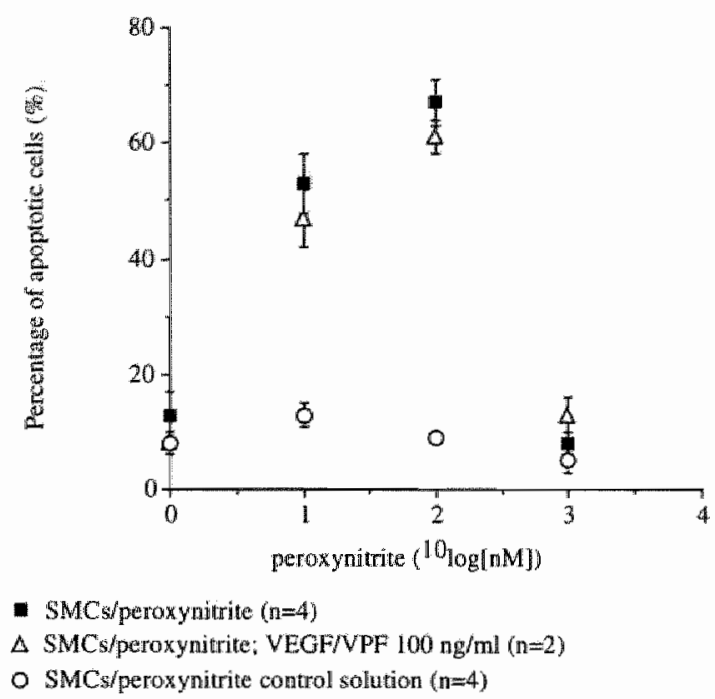

Figure 3. Percentage of apoptotic cells in a of rabbic aortic smooth muscle cells exposed to peroxynitrite for 48 hours. SMCs: smooth muscle cells; VEGFNPF: vascular endothelial growth factorivascular permeability factor; control refers to a solurion containing the decomposed form of peroxynitrite prepared from the same stock as the accive form; $n$ represents the number of wells exposed to defined reagents.

both smooth muscle cells and foam cells are observed; however, lipid-laden cells are absent in the media (Figure 4). At the site of the neointima significant quantities of peroxynitrite were produced as evidenced by the formation of nitrotyrosine (Figure $5 \mathrm{~A} / \mathrm{C}$ ). The oxidative stress imposed on the rhoracic aorta by persistent hypercholesterolemia is associated with the occurrence of apoptotic cell death in the neointima, but not in the media (Figure 5B/D). These findings were both present in WHHL rabbits and NZW rabbits with diet-induced hypercholesterolemia. Nitrotyrosine deposition and apoptotic nuclei were absent in the control animals (data not shown).

Transmission electron microscopy was performed at several levels of the thoracic aorta harvested from cholesterol-fed rabbits and rabbits maintained on regular chow to identify cells with ultrastructural changes of apoptosis. Again, apoptotic cells illustrating typical features such as condensation of nuclear chromatin and cell shrinkage without apparent damage of other cellular organelles were present in the neointima, but not in the media (Figure 6).

DNA laddering, another sign of apoptosis, was observed in the vessels harvested from WHHL and NZW rabbits after 10 weeks of high cholesterol feeding (Figure 7). In rabbits kept on regular chow or on a 6 weeks high cholesterol dier the occurrence of intimal thickening was absent. In these vessels DNA laddering was also absent (data not shown). 

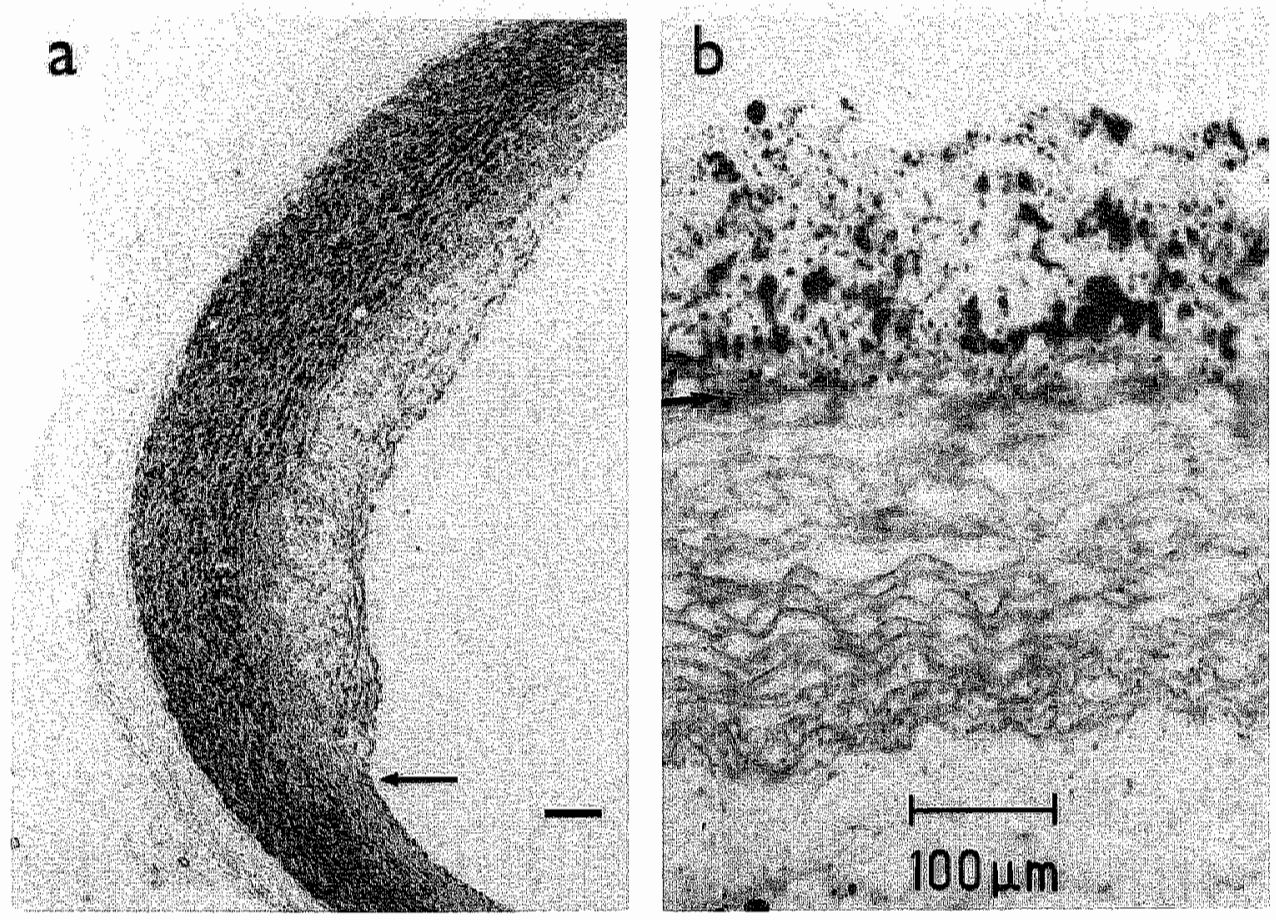

Figure 4. The occurrence of smooth muscle cells and foam cells in the neointimat of a cholesterol-fed rabbit aorta. A: Smooth muscle cells (SMCs) are identifiec by a red color representing $\alpha$-actirn. The density of SMCs in the neointima is lower than in the media. The arrow indicates the internal elastic lamina (IEL) on top of which the intimal lesion has occurred. The spacebar indicates $50 \mu \mathrm{m}$. The space bar indicates $100 \mu \mathrm{m}$ "B: Foam cells are stained red with Oil Red $O$. The arrow indicates the IEL.

\section{Discussion}

From this study, it can be concluded that $\mathrm{ONOO}^{-}$applied to vascular SMCs and ECs in culture induces apoptosis. However, VEGF/VPF abrogated the occurrence of apoptosis in ECs. Furthermore, ONOO produced by hypercholesterolemia-induced ncointimal lesions appears to be associated with apoptotic cell death in vivo.

Oxidative stress, leading to the formation of free radicals, has been implicated to generate cell toxicity in several acute and chronic diseases. In particular, activated macrophages in the vascular wall of vessels that have been exposed to hypercholesterolemia are capable to produce large quantities of $\mathrm{NO}$ and $\mathrm{O}_{2}-$ simultaneously in an equimolar fashion, ${ }^{27,28}$ resulting in the formation of $\mathrm{ONOO}^{-}$and its conjugate acid, peroxynitrous acid $(\mathrm{ONOOH})_{3}{ }^{29,30}$ both of which dramatically enhance toxicity of either $\mathrm{NO}$ or $\mathrm{O}_{2}$ alone. ${ }^{31,32,33}$ It has been demonstrated in vitro that $\mathrm{ONOO} / \mathrm{ONOOH}$ oxidizes DNA 


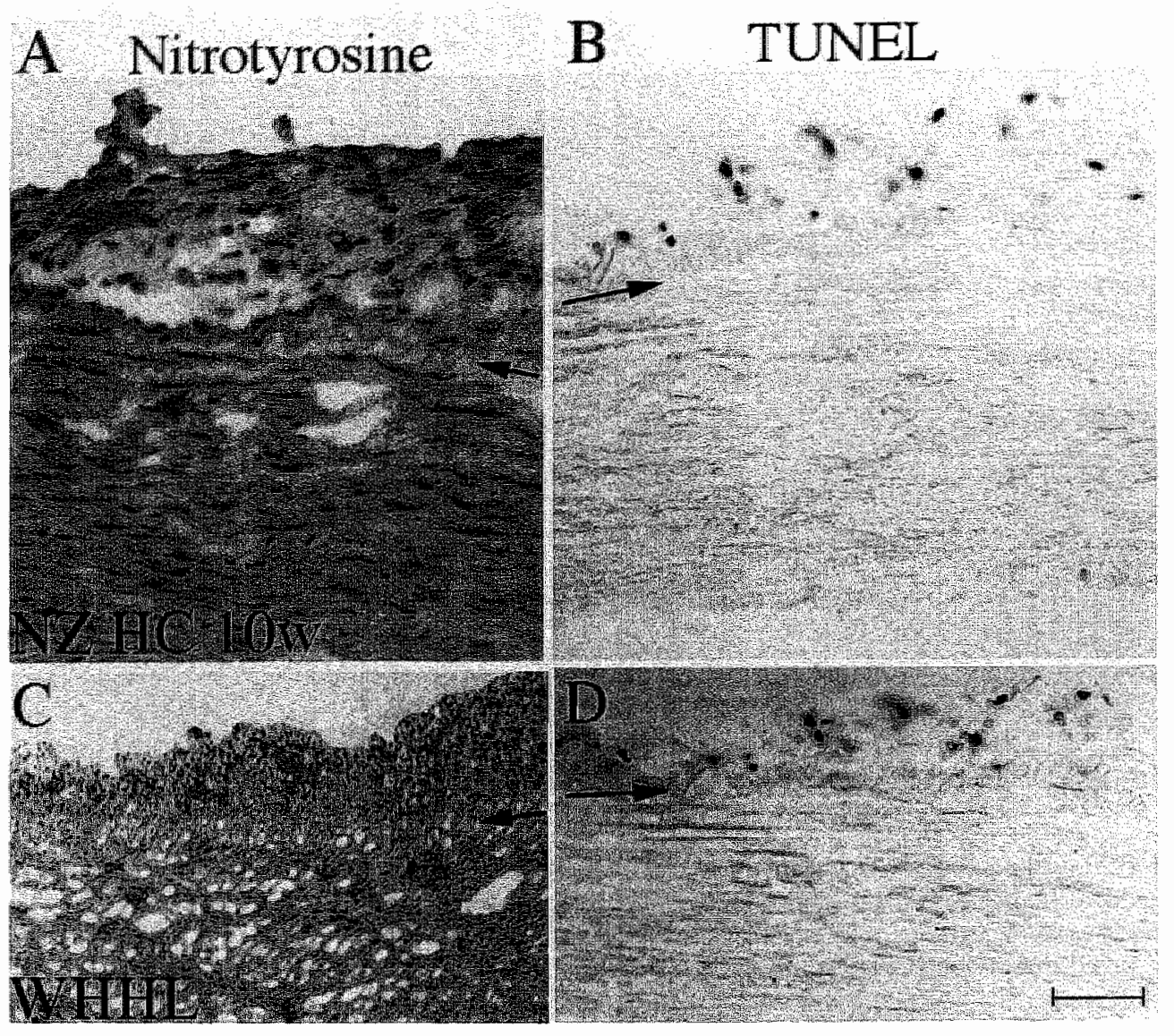

Figure 5. Peroxynitrite induces apoptosis in the hypercholesterolemia-induced neointima.

Nitroryrosinc, a marker for peroxynitrite formation, predominatily is presen in the neointima of the trypercholesterolemic rabbit arta (A/C). The occurrence of apoptosis is present in the same region (B/D). This colocalization is in accordance with in vitro experiments, where peroxynterte induced apoptosis. Arrows indicate the internal elastic lamina on top of which the neointima has formed. The spacobar indicates 50 Mm. NZ: New Zealand white rabbits; WHHL: Waranabe hericable hyperlipidemic rabbits; HC: high cholesterol diet; w: weeks; TUNEL: Terminal deoxynudeoridyl transterase AUorescein Nick End Labeling. 

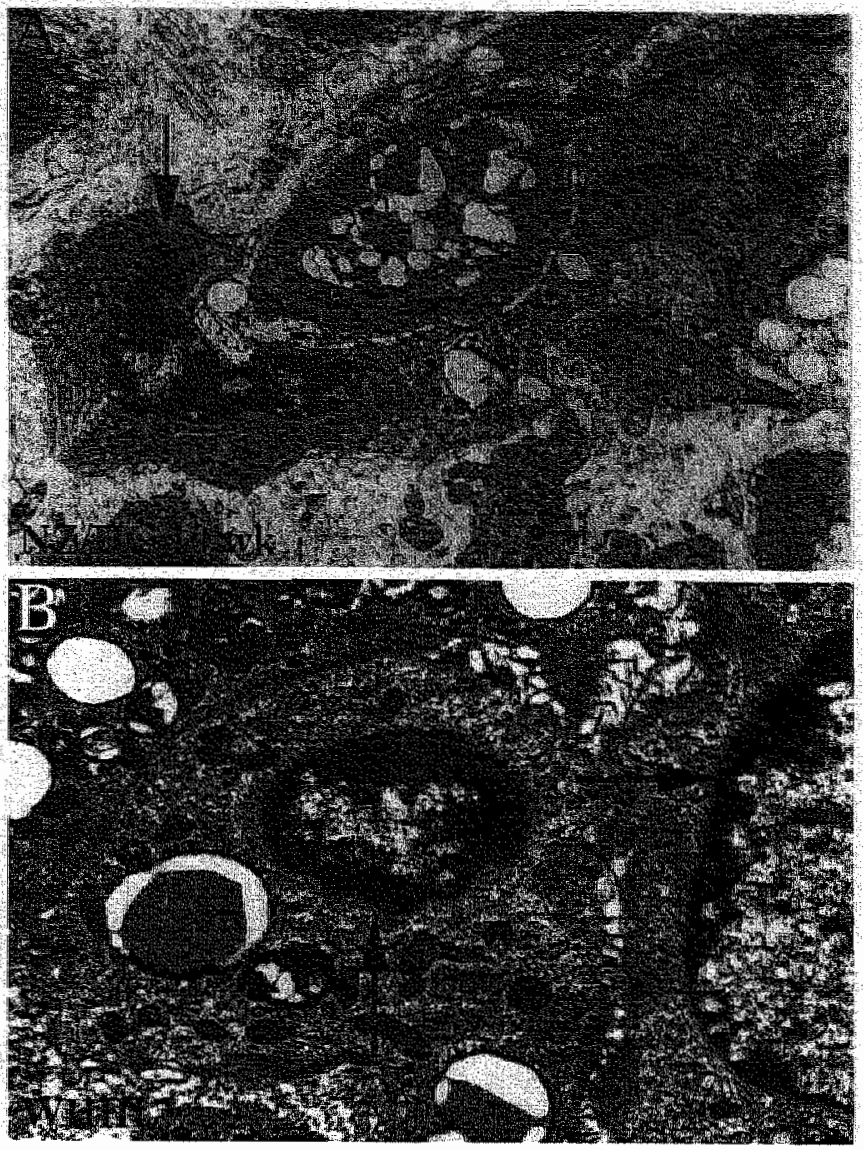

Figure 6. Ulerastructural identification of apoptotic nucle in the rabbit hyper-cholesterolemia-induced neointima. A: $3900 x ; B 890 x$. The vertical arrows indicate apoptoric nuclei, the horizontal arrows indicatie normal nuclei. Note that the apoptotic nuclei are compatced and show condensation of chromatin. They are surrounded with cyroplasmatic organelles without visible abnormalities. The white round artefacts indicate spots of lipid deposition. Lipid is washed our during fixation with gluteraldehyde. HC: high cholescrol diet; NZ: Now Zealand white rabbir: w: weeks; WHHL: Watanabe heritable hyperlipidemic rabbir. 


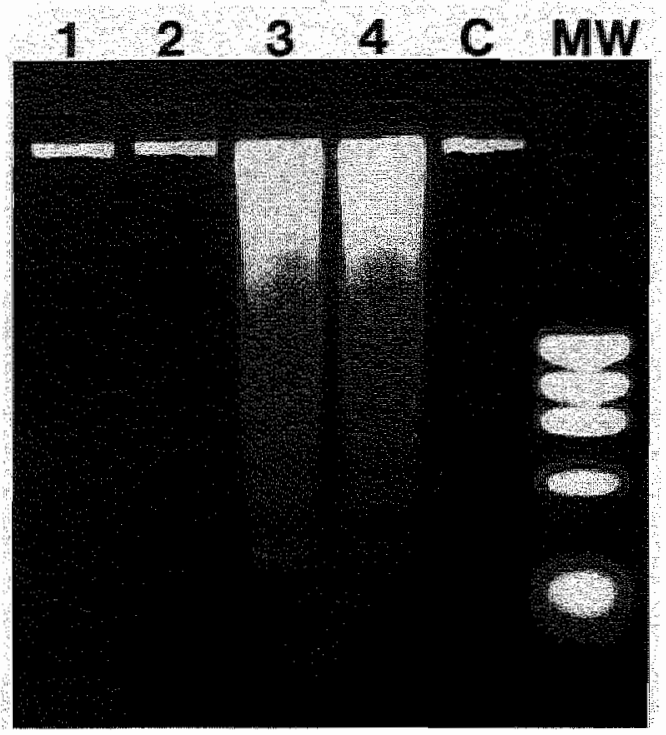

Figure 7. DNA laddering in vessels from rabbits with hypercholesterolemia-induced intimal. thickening. Agarose gel electrophoresis shows DNA fragmentation in vessels harvested from cholesterol-fed animals in which neointimal thickening had occurred; lane 1: New Zealand white rabbits (NZwr), regular chow, lane 2: NZwr, 6 weeks $1 \%$ cholesterol diet; lane 3: NZwr, 10 weeks $1 \%$ cholesterol dier; lane 4: Watanabe heritable hyperlipidemia rabbits; $\mathrm{C}_{\text {. }}$ DNA control; MW: Molecular weight marker.

bases, thus inhibiting DNA or protein synthesis. ${ }^{34,35}$ In addition, ONOO- $/ \mathrm{ONOOH}$ causes nitration of tyrosine residues, ${ }^{36,37}$ which has been shown to interfere with mitochondrial $\mathrm{Mn}$ superoxide dismutase, reducing the ability of cells to cope with additional oxidative stress. ${ }^{38}$ Finally, it has been reported that nitrotyrosine significantly abolishes phosphorylation of tyrosine residues in ECs in vitro, possibly affecting normal signal transduccion. ${ }^{39,40}$

Recently, several groups have suggested that oxidative stress is a key component of the apoptotic pathway in various cell types. ${ }^{41,42}$ For example, virus-induced apoptosis in prostate carcinoma cells was completely abrogated by the thiol antioxidant $\mathrm{N}$ acerylcysteine, one of the most effective inhibitors of transcription factor NF-KB. ${ }^{43} \mathrm{We}_{\mathrm{e}}$ showed the occurrence of apoptosis when vascular SMCs and ECs were exposed to oxidative stress both in vitro and in wivo. This observation is in accordance with the mechanism proposed by Schreck and Bacuerle, in which oxygen radicals are a common second messenger utilized by multiple stimuli to activate NF- $\mathrm{KB}$, which, under certain conditions, culminates in apoptotic cell death. ${ }^{44,45}$ In addition, overexpression of the proto-oncogene bcl-2, which has been shown to prevent apoptosis, funcrions in an antioxidant pathway by decreasing the generation of oxygen radicals. ${ }^{46,47}$ 
In contrast, exposure to high concentrations of $\mathrm{ONOO}^{-}$results in necrotic cell damage, which, in the case of ECs, can not be ameliorated by VEGF/VPF. Furthermore, apoptosis developed over many hours after administration of ONOO; whereas massive necrotic cell death could be documented within an hour. This observation explains the decrease in apoprotic figures at higher doses of $\mathrm{ONOO}^{-}$.

Interestingly, we observed that VEGF/VPF abrogated significantly the occurrence of apoptosis after administration of ONOO. VEGF/VPF binds to its protein kinase receptors, $F l k-1 / K D R$ and $F l t-1$, uniquely present on vascular ECs, which must dimerize to activate downstream signaling. ${ }^{24}$ However, evidence has been presented that protein kinases and protein phosphatases function as targets for oxidants and antioxidants. Anderson and colleagues have documented that oxidation of protein tyrosine kinase by reactive oxygen species culminates in the induction of $\mathrm{NF}-\mathrm{\kappa B}$, and the subsequent occurrence of apoptosis. ${ }^{48.49}$ Application of tyrosine kinase inhibitors abrogated this effect.

Alternatively, stimulation of tyrosine kinase receprors with NGF, PDGF, EGF, IGF-1, and, as shown in the present study, VEGF/VPF mediates cell survival by increasing PI-3 kinase activity. This effect was abolished in the presence of a PI-3 kinase inhibitor. Taken together, it seems likely that the balance of agenrs acting on protein tyrosine kinase influences the fate of the cell: its resulting signal transmits either survival or apoptosis (Figure 8). Further support supplied by Burton, who reported that control

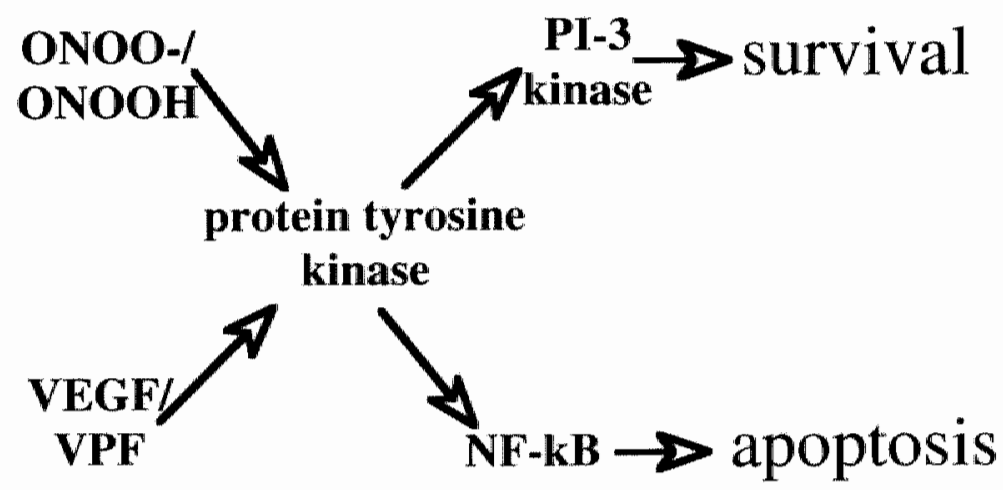

Figure 8. Schematic representation of survival/apoptosis signaling in the rabbit hypercholesterolemia-induced neointima. Vascular endothelial growil factor (VEGF)/vascular permeability facror (VPF) exerts a protecrive effect on endothelial cells by preventing them from undergoing apoptosis. The transmission of this survival signal involves acrivation of phosphatidylinositol 3 -kinase ([I-3 kinase). The redox balance of the cell at a given time is crucial for cell survival. An increasc in oxidative stress may overcome the effect of VEGF NPF and may culminate in apoptosis by activating nuclear factor-kappa $\mathrm{B}(\mathrm{NF}-\mathrm{KB})$. 
of cell proliferation versus apoptosis is mediated by receptor-determined events that often lead to the generation of reactive oxygen species, causing alternative responses depending on the specific cellulat tedox balance at a given time. ${ }^{50}$

In the vascular wall of the hypercholesterolemic rabbit apoptosis occurs in the neointima, but not in the media. The localization of apoptotic figures coincides with the deposition of nitrotyrosine, which is the stable and specific footprint of $\mathrm{ONOO}^{-}$and indicates the severity of oxidative stress. The formation of the highly reactive nitrogen oxides is likely to push the tissue redox balance towards mediating apoprosis.

In mature organisms, cell number is controlled as a result of the net effects of cell proliferation and cell death. Regulation of cell death is a crucial event in the developing neointima in this hypercholesterolemic model, since it allows for the elimination of cells that have been produced in excess and eventually account for parhological conditions such as impaired tissue perfusion by luminal narrowing. VEGF/VPF exerts its protective action by reducing free radical-induced apoptosis only on ECs, but not on SMCs, thus promoting cell loss in the neointima and reduction of additional cell adhesion and infiltration.

\section{References}

1. Thompson CB. Apoptosis in the pathogenesis and treatment of disease. Science 1995:267:14:56-1462

2. MeConkey D, Orrenius S. Signal transduction pathways to apoptosis. Trends Cell Biol 1994:4:370-375

3. Wyllie AH. Apoptosis: cell death in tissue regulation. J Pathol 1987:153:313-316

4. Cotcer TG. Programmed to die: cell death in the immune system. Immonologist 1993;1:181

5. Polunovsky VA, Wendt $\mathrm{CH}$, Ingbar DH, Peterson MS, Bitterman PB. Induction of endothelial cell apoptosis by TNF alpha: modulation by inhibitors of prorein synthesis. Exp Cell Biol 1994:314:584-594

6. Kerr JFR, Winterford CM, Harmon BV. Apoprosis: a basic biological phenomenon with wide ranging implications in rissue kinetics. Br/ Cancer 1972:26:239-257

7. Gavrieli $Y$, Sherman $Y$, Ben-Sasson SA. Identification of programmed cell death in situ via specific labeling of muclear DNA fragmentation. / Biol Cbem 1992;1 19:493.501

8. Gorcyea W, Gong J. Darzynkiewicz Z. Detecrion of DNA strand breaks in individual apoptotic cells by the in sim terminal deoxynucleotidyl transferase assays. Cancer Res 1993;53:1945-1.951

9. Ismer JM, Kearney M, Bortman S, Passeri J. Apoptosis in human arherosclerosis and resrenosis. Cinculation 1995;91:2703-27\|

10. Boudreau N, Sympson CI. Suppression of ICE and apoptosis in mammary epithelial odls by extracellular matrix. Science 1995:267:891-893

11. Vaux DL, Weissman IL, Kim SK. Prevention of programmed cell death in Caenorhabditis elegans by human bcl-2. Sctence 1992;25:8:1955-1957

12. Lorem 1, Sachs L. Control of apoprosis in hematopoiesis and leukemia by cytokines, tumor suppressor and oncogenes. Leukewina 1996;10:925-931

13. Dypbukr JM, Ankarcrona M, Burkirt M, Sjöholm $\AA$, Ström K, Orrenius S, Nicotera P. Different prooxidant levels stimulate growth, rrigger apoptosis, or produce necrosis of insulin-secreting RTINm5F cells. / Biol Chem 1994:269:30553-30560

14. Chiao C, Carothers AM, Grunberger D, Solomon G. Preston GA. Berrett JC. Apoprosis and alrered redox state induced by caffeic acid phenethyl ester (CAPE) in transformed rat fibroblast cells. Cancer Res 1995:55:3576-3583 
15. Lin K-T, Xue J-Y, Nomen M, Spur B, Wong PY.K. Peroxynirrice-induced apoprosis in HL-60 cells. JBiol Chem 11995:270:16487-16490

16. Butrke TM, Sandstrom PA. Oxidative stress as a mediator of apoptosis. Lmmumol Today 1994:15:7-10

17. Van der Zee R, Passeri J, Chen D, Silwer M, Isner JM. Peroxynitrite produced by hypercholwsterolemiainduced neoincima abrogares the protective action of vascular endothelial growth factor/vascular permeability factor on vascular endothelium. Submitred.

18. Van der Zee R, Murohara T, Luo Z, Zolmann F, Passeri J, Lekutar C, Isner JM. Vascular endorhelial growth factor/wascular permeability factor augments nirric oxide release from quiescent rabbir and human vascular endothelium. Cimculation 1997,95:1030-1037

19. Yao R, Cooper GM. Requirement for phosphatidylinositol-3 kinase in the prevencion of apoptosis by nerve growth factor. Science 1995;267:2003-2006

20. Ruderman NB, Kapeller R, White MF, Cantey LC. Acrivation of phosphatidylinositol 3-kinase by insulin. Prac Nat Acad Sci US A 1990;87:1411

21. Rodriguez-Tarduchy G, Collins MKL, Garcia I, Lopez-Rivas A. Insulin-like growth factor-ll inhibits apoptosis in hematopoieric cells. J Inumunol 1992;149:535

22. Minshall $\mathrm{C}$, Arkins $\mathrm{S}$, Freund $\mathrm{GG}$, Kelley KW. Requirement for phophatidylinositol 3'-kinase to protect hematopoieric progenitors against apoptosis depends upon the extracellular survival factor. J Immunal 1996:156:939-947

23. Hwang DL, Latus LJ, Lev RA. Effects of platelet-contained growth factors (PDGF, EGF, IGF-1, and TGF-beta) on DNA synthesis in porcine aortic snooth muscle cells in culrure. Exp Cell Res $1992 ; 200: 358-360$

24. de Vries C, Escobedo JA, Ueno H, Houck K, Ferrara N, Williams LT. The fms-like tyrosine kinase, a receptor for vascular endothelial growth factor. Science 1992;255:989-991

25. Millauer B, Wizigmann-Vopos $S_{n}$ Schurch H, Martinez R, Moller NPH, Risau W, Ulrich An High affinity VEGF binding and developmental expression suggests Fllk- 1 as a major regulator of vasculogenesis and angiogenesis. Cell 1993;72:835-846

26. Kolodgie FD, Karocs AS, Largis EE, Wrenn SM, Cornhill JF, Herderick EE, Lee SJ, Virmani R. Hypercholesterolemia in the rabbit induced by feeding graded amounts of low-level cholesterol. Merhodological considerations regarding individual variability in response to dietary cholesterol and development of lesion type. Anterioscler Thromb Vasc Biol 1996;16:1454-1464

27. Ohara J, Peterson TE, Harrison DG. Hypercholesterolemia increases endothelial superoxide anion production. J Clin Invest 1993;91:2546-2551

28. Pritchard KA Jr, Groszek L, Smalley DM, Sessa WC, Wu M, Villalon P, Wolin MS, Sremerman MB. Native low-densiy lipoprorein increases endothelial cell ritric oxide synthase gentration of superoxide anion. Circ Res 1995;77.510-518

29. Yang $G$, Candy TE, Boaro M, Wilkin HE, Jones $P$, Nathat NB, Saadalla-Nayar RA, Bhake DR. Free radical yields from the homolysis of peroxynitrous acid. Fre Radic Bial Med 1992;12:327-330

30. Crow JP, Spruell C, Chen J, Gunn C. Ischiropoutlos H, Tsai M, Smith CD, Radi R, Koppenol WH, Beckman JS. On the pH-dependent yield of hydroxyl radical products from peroxinitite. Fre Radic Biol Med 1994:16:331-338

31. Radi R, Beckman JS, Bush KM, Freeman BA. Peroxynitrite-induced membranc lipid peroxidarion: the cytotoxic pocential of superoxide and nitric oxide. Arcts Biochexn Bioptyy 1991;288:481-487

32. Miles AM, Bohle DS, Glassbrenner PA, Hansert B, Wink DA, Grisham MB. Modulation of superoxide-dependent oxidarion and hydroxylation reactions by nitric oxide. / Biol Chem 1996,271:4047

33. Zou MH, Ullich V. Peroxynirrite formed by simultaneous generation of nitric oxide and superoxide selecrively inhibits bovine aorric prostacyclin synthase FEBS Lett 1996;382:101-104

34. Douk T, Cader J. Peroxynitrite mediated oxidation of purine bases of nucleosides and isolared DNA. Free Radic Res 1996:24:369-380 
35. Srabo C, Zingareli B, O'Connor M, Salknan AL. DNA særand breakage, activarion of poly (ADPribose) synthetase, and cellular energy depletion are involved in the cyroroxicity of macrophages and smooth muscle cells exposed to peroxynitrite. Proc Natl Acad Sci U SA 1996:93:1753-1758

36. Ischiropoulos H, ALMendi AB. Petoxynitrite-mediated oxidative prorein modifications. FEBS Leta 1995:364:279-282

37. Beckmann JS, Ye YZ, Anderson PG, Chen J, Accavitri MA, Tarpey MM, White CR. Extensive nitration of protein tyrosines in human atheroselerosis detected by immunohistochemistry. Biol Chem Hoppe Soyler $19946 ; 375: 81-88$

38. Sxalbo C, Day BJ, Salman AL. Evaluation of the relative contriburion of nitric oxide and peroxynitrite to the suppression of mitochondrial respirarion in immunostimulared macrophages using manganese mesopotphyrin dismutase mimetic and peroxynirrite scawenger. FEBS Lett 1996:381:82-86

39. Gow A., Duran D, Malcolm S, Ischiropoulos H. Effeces of peroxynitrite-induced protein modification. on ryrosine phosphorylation and degradation. FEBS Lett 1996;385:63-66

40. Kong SK, Yim MB, Stadtman ER, Chock PB. Peroxyritrite disables the tyrosine phosphorylation regulatory mechanism: lymphocyte-specific tyrosine kinase fails to phosphorylate nitrated cde 2(6-20) $\mathrm{NH}_{2}$ peptide. Proc Nat Acad Sci U SA 1996;93:3377-3382

4. Payne CM, Bernstein C, Bernstein H. Apoptosis overvietw emphasizing the role of oxidarive stress. DNA damage, and signal-ransducrion pathways. Leak Lymphoma 1995;19:43-93

42. Lotem J, Peded-Kamar M, Groner Y, Sachs L. Cellular oxidarive stress and the control of apoptosis by wild-type p53, cytotoxic compounds, and cytokines. Proc Natl Acad SCI U S A 1996;93:9166-9171

43. Lin KI, Lee SH, Narayanan R, Baraban JM, Hardwick JM, Ratan RR. Thiol agents and Bd-2 identify an alphavirus-induced apoptotic parhway that requires accivation of the transcription factor NF-kappaa B. J Cell Biol 1995;131-1149-1161

44. Schreck R, Bacuerle PA. Assessing oxygen radicals as mediators in acrivation of inducible eukaryotic uranscription factor NF-kappa B. Methods Enzyno/ 1994;234:151 163

45. Schreck R, Abbermann K, Bacuerle PA. Nuclear factor kappa B: an oxidarive stress-responsive transcriprion factor of eukaryotic cells (a review). Free Radic Res Commun 1992;17:221-237

46. Hockenbery DM, Olevai ZN, Yin XM, Milliman CL, Korsmeyer SJ. Bd-2 functions in an antioxidane parthway to prevent apoptosis. Cell 1993;75:241-251

47. Veis DJ, Sorcnson CM, Shutrer JR, Korsmeyer SJ. Bd-2-deficient mice demonsratre fulminant lymphoid apoptosis, polycystic kidneys, and hypopigmented hair. Cell 1993;75:229-240

48. Anderson MT, Staal FJ, Gitler C, Herzenberg LA, Herzenberg LA. Separation of oxidant-initiated and redox-regalated steps in the NF-kappa B signal transduction pathway. Proc Nat Acad Sor USA 1994:91:11527-11531

49. Statil FJ, Anderson MT, 5aal GE, Herzenberg LA, Gitler C. Herzenberg LA. Redox regulation of signal rransducrion: tyrosine phosphorylarion and calcium inflex. Proc Nat Acad Sci U S A 1994:91:36193622

50. Burton RH. Superoxide and hydrogen peroxide in relacion to mammalian cell proliferation. Free Radica' Biol Mod 1995:18:775-794 


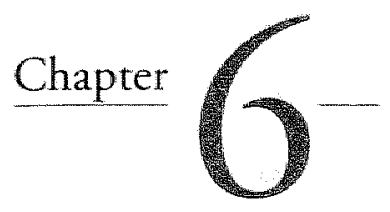

\section{General Discussion}

\section{Introduction}

From the data described in this thesis it can be concluded that vascular endothelial growth factor/vascular permeability factor (VEGF/VPF) augments nitric oxide (NO) release in the endothelium of mature vessels. This observation has two important implications. First, the presence of functional VEGF/VPF-receptors on adult endothelium, but not on other vascular cells, can be inferred, and, second, VEGF/VPF has a role in vascular biology besides mediating vasculogenesis in the developing embryo, ${ }^{1,2}$ or, in the adult, angiogenesis in pathological tissue especially in conjunction with ischemia. ${ }^{3,4,5}$

NO has been the subject of numerous studies, since this simple free radical gas is involved in many biological phenomena, such as vascular relaxation, ${ }^{6}$ inhibition of platelet $^{7}$ and leukocytes ${ }^{8}$ adhesion to vascular endorhelium, DNA modifications and repair, ${ }^{9}$ transcriptional regulation, ${ }^{10}$ and inhibition of mitogenesis of vascular smooth muscle cells. ${ }^{11}$ The release of $\mathrm{NO}$ by the endothelium is mandatory for preservation of vascular integrity. Consequently, disruption of vascular endothelium causes vasospasm, thrombus formation, infiltration of inflammatory cells, and proliferation/migration of smooth muscle cells. ${ }^{12,13}$ Also, degenerative changes of blood vessels occurring in aging, hypertension, and diabetes mellitus have been associated with dysfunctional endothelium, characterized by reduced endothelial cell (EC) NO production. ${ }^{14.15,16,17,18}$

\section{VEGF/VPF}

The data presented in this thesis are supportive for the concept that VEGF/VPF mediates a maintenace/repair role on quiescent mature vascular endorhelium (Figure 1). The biological activity of VEGF/VPF and the subsequent increased availability of functional NO released by the endothelium affects vessel function and patency and as a result protects the blood supply of depending organs. It can be hypothesized, that VEGF/VPF is a crucial growth factor/cytokine in preservation or restoration of sufficient tissue oxygen supply.

The biological activity of VEGF/VPF on mature quiescent vascular endothelium promores normal rissue metabolism and physiology. In addition, VEGF/VPF has been 


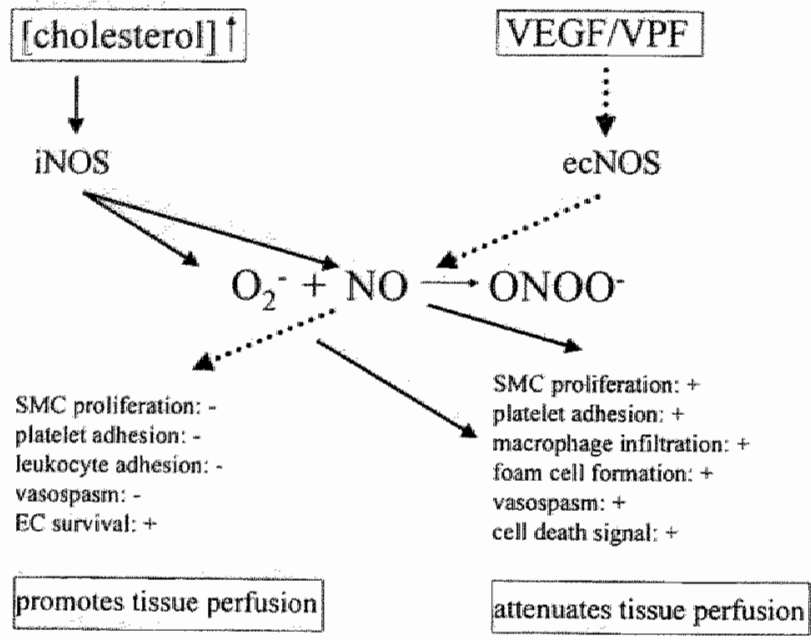

Figure 1. Schematic representation showing the opposite effects of NO depending on the type of NOS. VEGF/VPF: wascular endothelial growth factorlvascular permeability factor; NOS; nitric oxide synthase; i: inducible; ec: endothelial cell constitutive; $\mathrm{O}_{2}$; superoxide anion; ONOO-: peroxynitrite; SMC: smooth muscle cell; EC: endothelial cell.

shown to accelerate angiogenesis in ischemic tissue, ${ }^{19}$ thus restoring adequate oxygen supply. Gene transfer of a plasmid encoding $\mathrm{VEGF}_{165} / \mathrm{VPF}$ into the femoral artery of parients with severe peripheral atrery disease has been reported to be a useful therapeutical application. ${ }^{20}$ Other clinical applications of VEGF $165 / \mathrm{VPF}$ in ischemia-related disorders, such as severe trivascular coronary artery disease, or in expedited wound healing still require investigation.

\section{Hypercholesterolemia}

An ongoing assault on the vascular endothelial function was designed in a rabbit model of hypercholesterolemia to test the concept that VEGF/VPF can exert a repair/ maintenance function. Before the occurrence of intimal thickening, VEGF/VPF, but not acetylcholine, appeared to be capable of inducing normal vasorelaxation as a result of $N O$ release by the endothelial cells. However, after being exposed to higher levels of cholesterol for a longer period of time, a neointimal lesion consisting of macrophages/foamcells and smooth muscle cells had a detrimental effect on endothelial function, which could not be reversed by VEGF/VPF (Figure 1).

This observation has been related to the generation of highly reactive nitrogen oxides, mediated by macrophages/foamcells in the neointima. Especially the formation of peroxynitrite, a condensation of NO and the superoxide anion, has been shown to 
markedly increase oxidative stress. ${ }^{21}$ In this thesis, evidence is provided that oxidative stress causes apoptosis in the neointimal cells of a hypercholesterolenia-induced intimal lesion. However, binding of VEGF/VPF to its receptors, which are only present on ECs, ${ }^{22,23}$ mediates a survival signal and consequently reduces the incidence of apoptoric figures. Because of its narrow target cell specificity, oxidative stress-induced smooth muscle cell apoptosis was not affected by VEGF/VPF. The mechanism of action of VEGF/VPF in hypercholesterolemia might consist of promoting EC survival and reducing neointimal cellularity, rhus conserving normal vascular anatomy and function.

It has not been investigated whether VEGF/VPF might expedite recovery of EC function when cholesterol concentration returns to lower levels. Also, the effects of VEGF/VPF on endorhelial funcrion in patients suffering from complications of diabetes mellitus and/or hypertension are yet unknown. Survival of ECs and restoration of constiturive EC NO release may be crucial steps in preventing the occurrence of, (a) hypertension as a result of increased vascular tone, ${ }^{24}$ (b) vascular thrombosis and occlusive artery disease with subsequent jeopardized tissue perfusion; ${ }^{25}$ (c) adhesion of monocytes to the endothelium and infiltration in the subendothelial area, which is considered to be the initial event in atherosclerosis; ${ }^{26}$ and (d) mitogenesis of vascular smooth muscle cells, their migration to the luminal site, and the formation of (additional) intimal thickening. ${ }^{27}$

Recent studies demonstrate the beneficial effects of dietary suppletion of 1 -arginine in a rabbit model of hypercholesterolemia. ${ }^{28} \mathrm{~L}$-arginine constitutes the substrate for $\mathrm{NO}$ synthase (NOS), yielding NO during conversion to citrullin. In this thesis, evidence is provided that in hypercholesterolemia both EC constitutive NOS (ec-NOS) and inducible NOS (i-NOS) are expressed in the vascular wall. Especially i-NOS has been demonstrated in intimal cells and has been associated with the formation of highly reactive nitrogen oxides that impair the bioavailability of functional NO. Since binding sites for L-arginine have been reported on both ec-NOS and i-NOS, ${ }^{29}$ dierary supplementation might exert detrimental effects on endothelial function in patients with established vascular disease in which $\mathrm{i}-\mathrm{NOS}$ is likely to be present in intimal cells. Only normal blood vessels in which i-NOS is absent are likely to improve in endothelial function when increased $L$-arginine levels will become available exclusively for ec-NOS. For example, patients who underwent vascular bypass surgery might display an improved graft patency with a high L-arginine diet.

\section{Future investigations}

There is now considerable evidence that NO production is abnormal in patients with heart failure. ${ }^{30}$ Increased myocardial NO production as a result of expression of i-NOS by cytokines such as TNF- $\alpha$ contributes to reduced contracrility and myocyte injury. Further support is provided by the observation that progressive heart failure is a fearure of established septic shock. ${ }^{31}$ Overproduction of i-NOS mediared NO leads to marked vasodilatation and loss of normal cardiac funcrion. Likewise, in humans with left 
ventricular dysfunction, intracoronary infusion of the NO synthase inhibitor L-NMMA potentiated the inotropic response to peripheral infusion of dobutamine. ${ }^{32} \mathrm{Also}$, after cardiac transplantation allograft rejection occurs after the expression of large amounts of i-NOS in response to cytokines. ${ }^{33}$ Finally, it has been documented that i-NOS is abundandy expressed in patients with idiopathic dilated cardiomyopathy contributing to the detrimental effects of this disease. ${ }^{34}$ However, NO release from vascular endorhelium seems to be preserved and this maintains rissue perfusion by artenuaring the vasoconstrictive impulses by various neurohumoral factors.

The constiturive production of NO through ec-NOS activity has not been associated with altered myocardial contractility. However, evidence has been provided that immunemediated stimulation of $\mathrm{i}-\mathrm{NOS}$ leads to an excess of NO capable of inhibiring the positive inotropic and chronotropic responses to $\beta$-adrenergic receptor stimulation. ${ }^{35} \mathrm{In}$ addition, further increase in NO production mediated by muscarinic cholinergic stimulation of the heart is, at least partially, responsible for parasympathetic slowing of the heart rate and additional inhibition of $\beta$-adrenergic contractility. ${ }^{36}$ Thus, similar to the effects of hypercholesterolemia on the vascular wall, the maintenance function that ec-NOS mediated $\mathrm{NO}$ exerts on preserving tissue integrity can become overpowered by the cytokine-stimulated NO release via i-NOS with subsequent tissue injury.

It remains to be investigated whether selective enhancement of the putative ec-NOS activity and simultaneous inhibition of i-NOS activity favourably modifies the course of these conditions (Figure 1). Consequently, the signaling pathway involving the increased transcription of NOS induced with cytokines needs to be identified. Then, therapeutical interventions might be targeted at this specific pathway, at influencing ec-NOS m-RNA expression and stability, or at inhibiting i-NOS function. Recently, some evidence became available that 21-aminosteroid lazaroids might inhibit the formation of highly reactive nitrogen oxides species, such as peroxynitrire, and consequently reduce lethal cell injury during periods of energy depletion. ${ }^{37}$ It has been suggested that these type of reagents selectively attenuate the expression of $\mathrm{i}-\mathrm{NOS}$ in a dog model of ischemic liver injury. ${ }^{38}$ In contrast to $\alpha$-methylprednisolone, which exerts similar effects, lazaroids are devoid of glucocorticoid acrions, which is an appealling aspect for furure investigarions. In addition, in this thesis it has become evident that VEGF/VPF selectively stimulates ec-NOS acrivity as a result of the unique target cell specificity of this growth factor. For example, Von der Leyen and colleagues reported on in vivo transfer of the ec-NOS gene to augment consticurive NO producrion, which resulted in reduced mirogenesis of smooth muscle cells following balloon injury. ${ }^{39}$ This might constiture a novel approach in preventing restenosis after balloon angioplasty.

\section{Conclusions}

In conclusion, EC-derived $\mathrm{NO}$ has a crucial role in preserving the integrity of blood vessels. NO mediated through i-NOS rather exerrs cytotoxic effects. Promoring ec-NOS 
activity and simultaneously inhibiting - NOS expression and/or activity might constitute a new approach in the therapy of atherosclerosis-related vascular disease, heart fialure, allograft rejecrion or in the prevention of long-term complications of hypertension and for diabetes mellirus. ${ }^{40}$ Drugs are now being developed to selectively inhibit i-NOS expression. Furthermore, VEGF/VPF has been shown to selectively increase ec-NOS activity in quiescent endothelial cells of mature blood vessels. In addicion, VEGF/VPF has been shown to mediate a survival signal in ECs. More clinical trials are warranted to test the therapeutical potential of this unique growth factor.

\section{References}

1. Jakeman LB. Armanini M, Phillips HS, Ferrara N. Developmental expression of binding sites and messenger ribonuclic acid for wascular endothelial growth factor suggests a role for this prorein in vasculogenesis and angiogenesis. Endocrinology 1993;133:848-859

2. Breier G, Albrecht U, Sterrer $S$, Risau W. Expression of vascular endothelial growh factor during embryonic angiogenesis and endorhelial cell differentiacion. Developwent 1992;114:521-532

3. Detmar M, Brown LF, Claffey KP, Yeo K-T, Kocher O, Jackman RW, Berse B, Dworak HI: Owerexpression of wascular permeability factor/vascular endothelial grworh factor and its receptors in psoriasis. J Exp Med 1994;180:1141-1146

4. Plate KH, Breier G, Weich HA, Mennel HD, Risau W. Vascular endorhelial growth factor and glioma angiogenesis: coordinate induction of VEGF receptors. Distribution of VEGF protein and posible in wivo regulatory mechanisms. Int J Cancer 1994:59:520-529

5. Hashimoto E, Ogita T, Nakaoka T, Matsuoka R, Takao A. Kira Y. Rapid induction of vascular endothelial growth factor expression by transient ischemia in rat heart. A $w$ f Physio/ 1994;267:H1948. H1954

6. Ignarro LJ, Buga GM, Wood KS, Byrns RE. Endothelium-derived relaxing factor produced and released from artery and vein is nirric oxide. Proc Natl Acad Sci U S A 1987;84:9265-9269)

7. Radomski MW, Palmer RMI, Moncada S. Endogenous nüric oxide inhibirs human platelet adhesion to vascular endothelium. Lantet 1987;2:1057-1058

8. Kubes P. Suzuki M, Granger DN. Nitric oxide, an endogenous modularor of leukocyre adhesion. Proc Natl Acad Soi U S.A 1991;88:4651-4655

9. Ignarro LJ, Murad F, eds. Nitric oxide: biochemistry, molecular birologg, and therapeutic implications. In: Adwances in Pharmatology. New York, NY: Acadernic Press; 1995:34:1-516

10. Khan BV, Harrison DG, Obrych MT. Alexander RW. Medford RM. Nirric oxide regulates vascular cell adhesion molecule 1 gene expression and redox-sensitive transcriptional events in human vascular endothelial cells. Proc Nat Acad Sci U SA 1996;93:9114-9119

11. Yu S-M, Hung L-M, Lin C-C. CGMP'-elevating agents suppress proliferation of vascular smooth muscle cells by inhibiting the activation of epidermal growth factor signaling pathway. Cinculation 1997;95:1269-1277

12. Dusting GI. Nitric oxide in cardiowascular disonders. J Var Res 1995:32:143-161

13. Granger DN, Korthuis RJ. Physiologic mechanisms of postischemic tissuc injury. Anwa Rev Physiof $1995,57: 3111332$

14. Amrani M, Goodwin AT, Gray CC, Yacoub MH. Ageing is associared with reduced basal and stimulated release of nitric oxide by the coronary endothelium. Acha Phyrot Scand 1996:157,79-84

15. Chorincath BB, Kong LY, Mao L, McCallum RE. Age-associated differences in TNF-allpha and nitric oxide production in endotoxic mice. / Immatol 1996;156:1525-1530 
16. Mantelli L, Amerini S. Ledda F. Roles of nitric oxide and endorhelium-derived hyperpolarizing factor in vasorelaxant effect of acetylcholine is infuenced by aging and hyperension. / Cardiovase Pharmacol $1995: 25: 595-602$

17. Williams SB, Cusco JA, Roddy MA, Johnstone MT, Creager MA. Impaired nitric oxide-mediated vasodilation in parients with non-insulin-dependent diaberes mellitus. I Am Coll Cardiol 1996;27:567. 5774

18. Sex $W$, Mancusi $G$, Ralserger $G$, Schutz W. Agc-related changes in vascular reactivity in genetically diabetic rats. Phamacology 1995;50:238-246

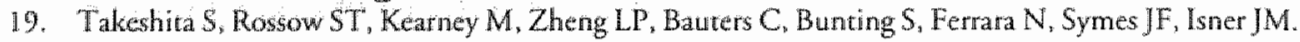
Time course of increased cellular proliferation in collateral arteries after administration of vascula: endothelial growth factor in a rabbit model of lower limb vascular insufficiency. Am I Pathol $1995: 147 \div 1649-1660$

20. Isner JM, Piecrek A, Schainfeld R, Blair R, Haley L, Asahara T, Rosenfield K, Razvi S, Walsh $K_{*}$ Symes JF. Clinical evidence of angiogenesis after arterial gene transfer of phVEGF 165 in patient with ischemic limb. Lander 1996;348:370.374

21. Beckman JS, Koppenol WH. Nitric oxide, superoxide, and peroxynitrite: the good, the bad, and the ugly. Am / Physiol 1996:271:C1424-C1437

22. Quinn TP, Peters KG, De Vries C, Ferrara N, Williams LT. Fetal liver kinase 1 is a receptor for vascular endothelial growth factor and is selectively expressed in wascular endothelium. Proc Nat Acad Sci US A 1993:90:7533-7537

23. Jakeman LB, Winer J, Bennetr GL, Altar CA, Ferrara N. Binding sites for vascular endothelial grown factor are localized on endothelial cells in adult rat tissues. / Clin Invest 1992;89:244-253

24. Johnson RA, Freeman RH. Sustained hypertension in the rar induced by chronic blockade of nitric oxide production. Am J Hypertension 1992;5:919-922

25. Yao SK, Akhtar $S$, Scorr Burden T, Ober IC, Golino P, Buja LM, Casscells W, Willerson JT. Endogenous and exogenous nitric oxide protect against intracoronary thrombosis and reocclusion after thrombolysis. Circulation 1995;92:1005-1010

26. Gerrity R. The role of the monocytes in atherogenesis, Itransition of blood-borne monocytes into foam cells in Faty lesions. Am J Pathol 1983;103:181-190

27. Groves PH, Banning AP, Penny WJ, Newby AC, Cheadle HA, Lewis MJ. The effects of exogenous nitric oxide on smooth muscle cell proliferation following porcine carotid angioplasty. Cardiovasc Res $1995 ; 30: 87-96$

28. Wang BY, Singer AH, Tsao PS, Drexler H, Kosek J, Cooke JP. Dietary arginine prevents atherogenesis in the coronary artery of the hypercholesterolemic ralubit. IAm Coll Cardiol 199:4:23:452-458

29. Sessa WC. The nitric oxide synthase family of proreins. J Varc Res 1994:31:131-143

30. Xic YW, shen W, Zha G, Xu X. Wolin MS, Hinze TH. Role of endothelium-derived nitric oxide in the modtuation of canine myocatdial mitochondrial respiration in witro. Implications for the development of heart failure. Circ Res 1996;79:381-387

31. Brady A. Nirric oxide, myocardial failure and sepric shock. Int / Catdiol 1995;50:269-272

32. Hare JM, Loh E, Creager MA, Colucci WS. Nitric oxide inhibits the positive inotropic response to betamadrenergic scimulation in humans with left ventricular dysfunction. Circalation 1995:92:21982203

33. Yang X, Chowdhury N, Cai B, Brett J, Marboe C. Sclacca RR, Michler RE, Cannon PI. Induction of myocardial nitric oxide synthase by cardiac allografe rejection. J Clin Invest 1994,94:714-721

34. Winlaw DS, Smythe GA, Keogh AM, Schyvens CG, Sprat PM, Macdonald PS. Increased nitric oxide production in heart failure. Lancet 1994;344:373-374

35. Hare JM, Colucci WS. Role of nitric oxide in the regulation of myocardial funcrion. Prog Cardiovas Dis 1995:38:155-166

36. Han X, Kobzik L, Balligand J-L, Kelly RA, Smich TW. Nirric oxide synthase (NOS3)-mediated cholinergic modulation of $\mathrm{Ca}^{2+}$ current in adult rabbit atrioventricular nodal cells. Corc Res $1996,78: 998-1008$ 
37. Fici G], Althaus IS, VonVoigdander PF. Effeces of lazaroids and peroxynitrite scovenger in a cell modet of peroxynitrite toxicity. Free Rudic Bial Med 1997;22:223-228

38. Ishizalki N, Zhu $Y$, Zhang S, Nemoto A, Kobayashi Y, Subbotin V, Stard TE, Todo S. Comparison of various lazaroid compounds for protection aganst ischemic liver injury. Tronplatatation 1997;63:202-208

39. Von der Lewen HE, Gibbons $G H$, Morishita $\mathbb{R}$, Lewis NP, Zhang L, Nakajima $M$, Kaneda $Y$, Cooke JP. Dzau VJ. Gene therapy inhibiring neointimal vascular lesion: in vivo transfer of endothelial cell nicric oxide synthase gene. Proc Nat Acad Sci US A 1995;92:1137-1141

40. Lindsay RM, Peer RS, Wilkie GS, Rossiter SP, Smith W, Baird JD, Willians BC. In wiwo and in vitio evidence of altered nitric oxide metabolism in she sponateously draberic, insulin-dependent BB/Edinburgh rax. Br J Pharmacol 1997;120:1-6 



\section{Summary}

Vascular endochelial cells have been shown to play a crucial role in preserving the patency of blood vessels throughout life. Nitric oxide (NO) produced by endothelial cells is an important secreted factor that mediates a great number of phenomena in vascular biology, all contributing to normal vessel anatomy and function.

Vascular endothelial growth factor/vascular permeability factor (VEGF/VPF) is a protein produced by vascular cells that is capable of selectively augmenting NO production by vascular endothelium. This observation provides inferential evidence for the expression of the VEGF-receptors, Flk-l/KDR and $F / t-l$, on mature, quiescent endothelium. More support for this notion is provided by the demonstration of both receptor $\mathrm{m}$-RNA and the expressed proteins in human blood vessels used for coronary bypass grafting.

NO is continuously released by healthy vascular endothelium. This free radical gas can be produced in other cell types as well, however, this occurs only after the expression of an inducible nitric oxide synthase (i-NOS). We now show that in a rabbit model of hypercholesterolemia, $\mathrm{i}-\mathrm{NOS}$ becomes abundantly present in neointimal macrophages/foam cells. The produced NO by this type of cells reacts with simultaneously produced superoxide anions $\left(\mathrm{O}_{2}^{-}\right)$to generate peroxynitrite (ONOO$\left.{ }^{-}\right)$, another potent oxidizing molecule. The generation of peroxynitrite, however, tremendously increases oxidarive stress in the vessel wall. Peroxynitrite has been shown to cause numerous detrimental cellular effects and importantly interferes with normal endorhelial function.

In hypercholesterolemia, VEGF/VPF appeared to preserve endorhelial function. Only after the occurrence of intimal thickening and the generation of peroxynitrite the putative function of VEGF/VPF becomes overwhelmed. Evidence is provided that VEGF/VPF protects ECs from peroxynitrite-induced apoptosis. Since the VEGF/VPF-receptors are uniquely expressed on ECs, this protective effect is not exerted on neointimal cells. Consequently, apoptotic figures were extensively demonstrated in the neointima. The reduction of cellularity in the intima is likely to promote vascular patency.

NO mediated via i-NOS has been shown to be involved in the pathophysiology of heart failure, sepric shock, and allograft rejection. Also, reduced ec-NOS activity has been reported in vascular endorhelium of patients with essential hypertension or diabetes mellitus. Future studies are necessary to test the hypothesis that selectively augmenting ec-NOS mediated NO, for example with VEGF/VPF, and simultaneously inhibiting i-NOS mediated NO release might have a beneficial effect in these highly prevalent cardiovascular disorders. 



\section{Samenvatting}

De endorheelcellen van bloedvaten zijn van doorslaggevend belang voor goed doorgankelijke bloedvaten als men ouder wordt. Stikstofoxide (NO), dat uit endorheelcellen afkomstig is, vervult een belangrijke rol in het behoud van een normale functie en anatomie van bloedvaten.

Vascular endothelial growth factor/vascular permeability factor (VEGF/VPF), een eiwit dat onder meer in bloedvaten wordt angemaakt, verhoogt de productie van srikstofoxide (NO) in endotheelcellen. Hieruit kan bovendien worden afgeleid dat receptoren voor VEGF/VPF, Flk-1/KDR en $F / t-1$, aanwezig zijn op niet geactiveerde endotheelcellen. Voorts wordt in dit proefschrift aangetoond dat deze receptoren aanwezig zijn op bloedvaten die als omleidingen worden gebruikt bij operaties voor kransslagadervernauwing. VEGF/VPF kan dus een nutrige werking hebben bij het behoud van een goede doorgankelijkheid van deze omleidingen.

NO wordt in kleine hoeveelheden continu geproduceerd door endotheelcellen. NO kan ook in grote hoeveetheden door andere cellen worden aangemaakt, echter alleen nadat een bepaald enzym, "induceerbaar-NO synthase" (i-NOS), tot uitdrukking is gekomen onder invloed van prikkels uit de omgeving. In dit proefschrift wordt aangetoond, dat in konijnen met verhoogde cholesterolspiegels i-NOS overvloedig wordt gezien in macrofagen/schuimcellen, die gelocaliseerd zijn op plaatsen waar bloedvatvernauwing optreedt. De hoge concentraties $\mathrm{NO}$ die op deze plaatsen worden geproduceerd reageren mer gelijkrijdig gevormde zuurstofradicalen $\left(\mathrm{O}_{2}^{-}\right)$, waardoor peroxynitrier (ONOO-) ontstaat. Peroxynitriet heeft een buitengewoon sterk oxiderend vermogen en oefent daardoor zeer schadelijke effecten nit op de vatwand.

VEGF/VPF blijkc bloedvat-endotheel echter te kunnen beschermen tegen de effecten wan verhoogd cholesterol. Pas nadat bloedvatvernauwing is opgetreden en peroxynitrier wordt gewormd, verliest VEGF/VPF zijn beschermende functie. Wel bijkt uit dit proefschrift dat VEGF/VPF voorkomt dat endotheelcellen te gronde gaan onder invloed van peroxynitriet. Doordar de receproren voor VEGF/VPF uitsluntend aanwezig zijn op endotheelcellen, zullen andere cellen betrokken bij vaatvernauwing wel te gronde gaan, waardoor het dichtslibben van bloedvaten wordt geremd.

NO dat geproduceerd wordt in cellen waar i-NOS tor uitdrukking is gekomen blijkt ook een rol te spelen bij het ontstaan van harffalen, septische shock, en afstotingsreacties na orgaantransplantatie. Ook is het zo, dat verminderde afgifte van NO door endorheelcellen wordt gevonden bij patiënten met hoge bloeddruk of suikerziekte. Onderzoek zal moeten uitwijzen of het versterken van de NO productie in endotheelcellen en het selectief afremmen van i-NOS activiteit bovengenoemde aandoeningen, die vaak voorkomen, gunstig kan beìnvloeden. 



\section{Dankwoord}

Bij de voltooïng van dit proefschrift wil ik Dr. G.J.H. den Otrolander bedanken voor zijn doortastende wijze waarop hij $\mathrm{mij}$ in de klinische gezondheiszorg heeft geïntroduceerd. Zijn betrokkenheid bij het onderwijs van medisch studenten heeft in ruimere zin een belangrijk stempel gedrukt op het klinisch denken van meerdere generaties medici.

Aan Prof. Dr. H.J.J. Wellens ben ik dank verschuldigd voor de uitstekende opleiding tor cardioloog. Bij de steeds groeiende mogelijkheden in de moderne cardiologie van hoogwaardige diagnostische en therapeutische middelen, van moleculaire biologie tot de nieuwste interventiecatheter, blijft hij op fascinerende wijze nieuwe technieken integreren in de cardiologie zonder daarbij de bestaande mogelijkheden uir het oog te verliezen. Zijn fenomenale kennis van het internationale wetenschappelijke of cardiologische landschap is van onschatbare waarde. Hij maakte samen met de Wynand N. Pon Stichting de buitenlandse stage bij Jeffrey M. Isner mogelijk, waar ik het onderzoek voor dit proefschrift heb kunnen voltooien.

Jeff, it was an absolute delight to work in your lab for one year. You have guided my research the way I could only dream of. I admire your driving force, and because of your friendly approach, you created the perfect atmosphere for achievement. I wished I cowld tum back the time and experience that year once over again. Please extend my regards to all the coworkers in your lab.

Prof. Dr. M.J.A.P. Daemen is een onmisbare schakel geweest bij het kritisch omvormen van mijn onderzoeksresultaten tot een degelijk geheel waarbij ruime aandacht werd besteed aan de continuïteit in de verschillende hoofdstukken soms zelfs tot in de keinst mogelijke details.

Uiteraard noem ik veel te weinig mensen. Ik moet natuurlijk alle medewerkers van de Vakgroep Cardiologie en ook de verpleegkundigen van het AZM noemen, omdar zij samen bijdragen aan een sfeer waarin wetenschappelijk onderzoek, klinische zorg en een goede onderlinge verstandhouding hand in hand kunnen gaan.

Maar de grootste bijdrage is geleverd door mijn vrouw Margreer, want als zij thuis niet zo perfekt en liefdevol aanwezig zou zijn, dan zou dit proefschrift zeker nooit tot stand zijn gekomen. 



\section{Curriculum Vitae}

behorende bij

Marinus Cornelis van der Zee

geboren 25 september 1960

te Franeker (Friesland).

Na middelbaar onderwijs aan het Christelijk Gymnasium te Leeuwarden, afgerond mer een $\beta$-diploma in 1980, werd de militaire dienstplicht vervuld van 1980-1981. Aansluitend werd gestart met de studie in de Geneeskundige Wetenschappen te Gent (B), waar het kandidaatsexamen werd verkregen in 1984. De studie werd voortgezet aan de Erasmus Universiteit te Rotterdam. Hier werd het artsexamen behaald in 1988. Hierna werd gewerkt als arts-assistent in het toenmalige Bergweg Ziekenhuis op de afdeling Interne Geneeskunde onder Dr. G.J.H. den Ottolander. In 1990 werd begonnen met de opleiding tot cardioloog in het Academisch Ziekenhuis Maastricht met Prof. Dr. H.J.J. Wellens als opleider. Van 1995-1996 werd stage gelopen aan het St. Elizabeth's Medical Center te Boston bij Jeffrey M. Isner. Hier werd het promotieonderzoek verricht. De opleiding tot cardioloog werd afgerond op 1 maart 1997; aansluitend wordt gewerkt als cardioloog bij het Academisch Ziekenhuis Maastricht.

Diploma's

1980

1988

1995

1996

1997
VWO- $\beta$ Christelijk Gymnasium; Leeuwarden

Artsexamen Erasmus Universiteit; Rotterdam

Educational Commission for Foreign Medical Graduates (ECFMG) Frankfurt/Philadelphia

Research Fellow Tufts University, School of Medicine; Boston

Cardioloog; Maastricht 



\section{Publicaties}

Determination of plasminogen activator inhibitor in human plasma and blood platelets and its clinical relevance. Griep EN, Van der Zee R, Orrolander GJHd. Fibrinolysis $1990 ; 4(2): 141-4$.

Electrocardiographic diagnosis of reperfusion during thrombolytic therapy in acute myocardial infarction. Doevendans PA, Gorgels AP, Van der Zee R, Partouns J, Bär FW, Wellens H]. Am J Cardiol 1995;75:1206-1210

Vascular Endothelial Growth Factor(VEGF)/Vascular Permeability Factor (VPF) augments nitric oxide release from quiescent rabbit and human vascular endothelium. Van der Zee R, Murohara T, Luo Z, Zollmann F, Passeri J, Lekutat C, Isner JM. Circulation 1997;95: 1030-1037.

Isolation of putative progenitor endothelial cells for angiogenesis. Asahara T, Murohara T, Sullivan A, Silver M, Van der Zee R, Li T, Witzenbichler B, Schatteman G, Isner JM. Science 1997;275:964-967

Estradiol accelerates functional endorhelial recovery after arrerial injury. Krasinski K, Spyridopoulos I, Asahara T, Van der Zee R, Isner JM, Losordo DW. Circulation 1997:95:1768-1772

Vascular endothelial growth factor/vascular permeability factor produces nitric oxide-dependent hypotension. Evidence for a maintenance role in quiescent adult endothelium. Horowitz JR, Rivard A, Van der Zee R, Hariawala M, Sheriff DD, Esakof DD, Chaudry GM, Symes JF, Isner JM. Arterioscler Thromb Vasc Biol 1997, in press

Reduced intimal thickening following $\alpha_{4} \beta_{3}$, blockage is associated with smooth muscle cell apoptosis. Van der Zee R, Murohara T, Passeri J, Kearney M, Skopicki H, Cheresh DA, Isner JM. Cell Adbesion Commun 1997, in press.

The human internal mammary artery releases more nitric oxide in response to Vascular Endothelial Growth Factor (VEGF)/Vascular Permeability Factor (VPF) than the human saphenous vein. Van der Zee R, Passeri J, Horowitz JR, Symes JF, Isner JM. Submitted as full paper; accepted as abstract in Circulation, 1997. 
Peroxynitrite elaborated by hypercholesterolemia-induced neointima abrogates the protective action of Vascular Endorhelial Growth Factor (VEGF)/Vascular Permeability Factor (VPF) on vascular endothelium. Van der Zee R, Passeri J, Chen DF, Silver M, Isner JM. Submitted.

Vascular Endothelial Growth Factor (VEGF)/Vascular Permeability Factor (VPF) prevents peroxynitrite-induced apoptosis requiring phosphatidylinositol- 3 'kinase. Van der Zee R, Passeri J, Sullivan A, Skopicki H, Isner JM. Submitted as full paper; accepted as abstract in Circulation, 1997. 